Northwestern University School of Law Northwestern University School of Law Scholarly Commons

Faculty Working Papers

2012

\title{
Monopolies and the Constitution: A History of Crony Capitalism
}

Steven G. Calabresi

Northwestern University School of Law, s-calabresi@law.northwestern.edu

Larissa Price

\section{Repository Citation}

Calabresi, Steven G. and Price, Larissa, "Monopolies and the Constitution: A History of Crony Capitalism" (2012). Faculty Working Papers. Paper 214.

http://scholarlycommons.law.northwestern.edu/facultyworkingpapers/214

This Working Paper is brought to you for free and open access by Northwestern University School of Law Scholarly Commons. It has been accepted for inclusion in Faculty Working Papers by an authorized administrator of Northwestern University School of Law Scholarly Commons. 


\section{Monopolies ANd THE Constitution: A History of Crony CAPITAlism}

\section{By Steven G. Calabresi ${ }^{1}$ \& Larissa Price $^{2}$}

ABSTRACT: This article explores the right of the people to be free from government granted monopolies or from what we would today call "Crony Capitalism." We trace the constitutional history of this right from Tudor England down to present day state and federal constitutional law. We begin with Darcy v. Allen (also known as the Case of Monopolies decided in 1603) and the Statute of Monopolies of 1624, both of which prohibited English Kings and Queens from granting monopolies. We then show how the American colonists relied on English rights to be free from government granted monopolies during the Revolutionary War period as, for example, when American colonists protested against the East India Company's trade monopoly by holding the Boston Tea Party. We show that hatred of trade monopolies led in part to the American Revolution. During the drafting and debates on the federal Constitution, Thomas Jefferson and George Mason, as well as several Antifederalists, expressed grave concern about government grants of monopoly power. The new federal government was thus only given the enumerated power to create monopolies in the patent and copyright areas, and the Framers at Philadelphia deliberately chose not to give Congress the power to charter corporations which might be used to grant monopolies. During the Jacksonian era, it was a hatred of government grants of monopoly that helped to lead to President Jackson's killing of the federally incorporated Bank of the United States. The same sentiment led as well to the Supreme Court's narrowing of the Contract Clause in the Charles River Bridge case. Many state laws were struck down during the Jacksonian era for being monopolies, class laws, or grants of special privilege. By the 1850s, the Abolitionists themselves had begun to borrow the antimonopoly idea to argue that slavery was a constitutionally forbidden monopoly by slave owners of the labor of African Americans. By 1868, when the Fourteenth Amendment was adopted, the Reconstruction Congress was firmly opposed to all forms of class legislation, grants of special privilege, or of monopoly. Concerns about the evils of government granted monopolies were thus central to the original meaning of the Fourteenth Amendment. We argue that Americans have a constitutional right to be free from government grants of monopoly and other forms of class legislation because of: 1) the rich English and American colonial history with respect to the right to be free from monopolies; 2) the state constitutional law bans on monopolies, class legislation, and special grants of privilege; 3) the limiting of federal enumerated power to grant monopolies to the patent and copyright context; and 4) the original meaning of the Fourteenth Amendment. We think that the Slaughter-House Cases were wrongly decided, and we argue against rational basis review in economic liberties cases. We provide historical and legal arguments that defend the classical liberalism of John Tomasi in his new book defending economic liberty, Free Market Fairness.

1 Class of 1940 Professor of Law, Northwestern University. Copyright 2012—all rights reserved.

2 JD Class of 2012, Northwestern University. We would like to thank Stephen Presser for his helpful advice and comments and Pegeen Bassett for her invaluable skill and help as our research librarian. We dedicate this article to Professor Richard Epstein from whom we have learned so much about economic liberty. 


\section{TABLE OF CONTENTS:}

I. A BRIEF History: How Monopolies CAME To BE HATED ................................................ 7

A. The English Experience with Monopolies ..................................................................... 7

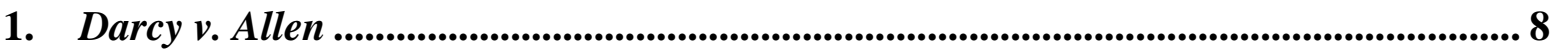

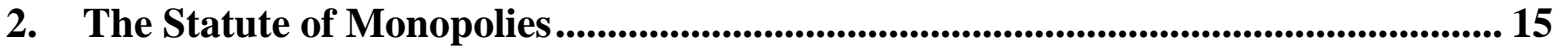

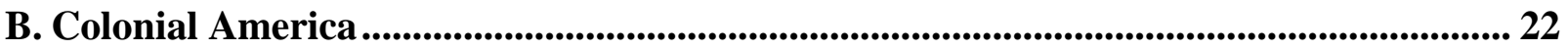

II. Monopolies \& The Federal ConStitution..................................................................... 28

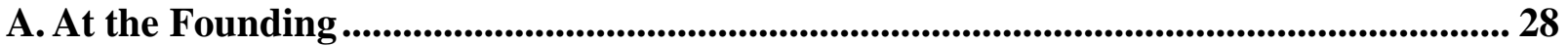

B. Monopolies \& the Original Federal Constitution..................................................... 35

C. The Fourteenth Amendment: A Ban on Class-Based Legislation ...................................... 42

D. Economic Liberty Cases: Slaughter-House, Lochner, \& the New Deal Cases ............... 61

E. “Private” Monopolies \& Federal Antitrust Law .................................................... 75

III.MONOPOLIES \& THE STATE CONSTITUTIONS ............................................................ 87

A. A Tradition Rooted in Jacksonian Democracy \& Changes in Corporate Law ............. 88

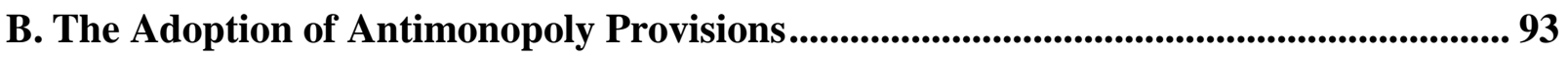

1. Provisions Adopted at the Founding …............................................................ 93

2. The Middle to Late Nineteenth Century ............................................................. 95

3. The Progressive Era ..................................................................................................... 101

C. The Application of Those Provisions ............................................................................. 104

1. Challenging Licensing Requirements................................................................. 105

2. Striking Down Taxes that Benefit Preferred Industries......................................... 109

3. Challenging Monopolies for Doing Business with the Government ....................... 110

4. Combating Price Controls ............................................................................... 112

D. Why Have So Few States Adopted Antimonopoly Provisions? ................................. 114

CONCLUSION ...................................................................................................................................... 117 
Government-conferred monopolies granted by English Kings and Queens plagued England in the late sixteenth and early seventeenth centuries, leading to both the Case of Monopolies and a parliamentary Statute of Monopolies. While today the word "monopoly" is generally used to refer to the private accumulation of economic power, this is not the meaning that was originally attached to the term. The original meaning of the word "monopoly" was an exclusive grant of power from the government —in the form of a "license" or "patent" — to work in a particular trade or to sell a specific good. The word "monopoly" comes from the Greek roots “mono" meaning single or one and "polein" meaning to sell ${ }^{3}$ The Greek word “monopolion” referred to an exclusive legal right of sale issued by the government. Sir Edward Coke defined monopolies in the early 1600's as being:

Institution[s] or allowance[s] by the King by his grant, commission, or otherwise to any person or persons, bodies politic or corporate, of or for the sole buying, selling, making, working or using of anything whereby any person or persons, bodies politic or corporate, are sought to be restrainted of any freedom or liberty that they had before, or hindered in their lawful trade. ${ }^{4}$

Samuel Johnson's dictionaries from the eighteenth century defined a monopoly as "the exclusive privilege of selling anything."5 The 1828 First Edition of Noah Webster's

American Dictionary of the English Language defined a monopoly as being:

The sole power of vending any species of goods, obtained either by engrossing the articles in market by purchase, or by a license from the government confirming this privilege. Thus the East India Company in Great Britain has a monopoly of the trade to the East Indies, granted to them by charter. Monopolies by individuals obtained by engrossing, are an offense prohibited by law. But a man has by natural right the exclusive power of vending his own produce or manufactures, and to retain that exclusive right is not a monopoly within the meaning of the law. ${ }^{6}$

\footnotetext{
${ }^{3}$ THE BARNHART DiCTIONARY OF ETYMOLOGY 674 (Robert K. Barnhart ed. 1988).

${ }^{4}$ EDWARD COKE, THIRD PART OF THE INSTITUTES OF THE LAW OF ENGLAND 181 (1664).

${ }^{5}$ See, e.g., SAMUEL JohnSOn, A DiCTIONARY OF THE ENGLiSH LANGUAGE (6th ed. 1785); SAMUEL JOHNSON, A DiCTIONARY OF THE ENGLISH LANGUAGE (3d ed. revised 1768); SAMUEL JOHNSON, A DiCTIONARY OF THE ENGLISH LANGUAGE (3d ed.1766).

${ }^{6}$ NoAh Webster, American Dictionary of the English LANGUAGE (1828).
} 
The American colonists shared English concerns about exclusive monopoly privileges issued by the government, which imposed enormous costs on the general public and especially on consumers. George Mason, Thomas Jefferson, and several Antifederalists argued in favor of including an antimonopoly clause in the federal Constitution. Although no such clause was added at the federal level, constitutional drafters in two states recognized the danger of monopolies and prohibited government granted monopolies in their state constitutions. More states added antimonopoly clauses to their state constitutions in the first one hundred years after the federal constitution was adopted. Others prohibited monopolies using different language, including clauses that forbade the giving of exclusive privileges to one class of citizens over another, or clauses that forbade the abridging of the privileges or immunities of citizens. The Framers of the Fourteenth Amendment to the federal constitution shared this concern with what they called class legislation, a concern which led four U.S. Supreme Court justices to say that state granted monopolies were unconstitutional in an important dissent in 1873 in The SlaughterHouse Cases. $^{7}$

The objection to government granted monopolies and to forms of caste or class legislation is not only part of this country's history: it is also relevant today. In a recent op-ed in the Washington Post, George Will describes a legal challenge that has just been brought to the constitutionality of a monopoly granted by the state of Washington to a ferry boat company. ${ }^{8}$ The ferry boat company has a legal monopoly on boat service to a town that can otherwise only be reached by plane. The challengers to the Washington state law setting up the monopoly are residents of that remote town who wish to open a competing boat service to provide an easier

\footnotetext{
${ }^{7} 83$ U.S. 36 (1873).

${ }^{8}$ George Will, Testing the Waters of Economic Liberty, WASH. Post, Dec. 18, 2011, available at http://patriotpost.us/opinion/george-will/2011/12/18/testing-the-waters-of-economic-liberty/.
} 
way to get to their town. As George Will explains, the problem of government conferred monopolies is not unique to one town in Washington state because it is now routine in many states for the government to require licenses for various industries, often for the purpose of bestowing economic favors. Licensing requirements of this kind sometimes take the form of a complete prohibition (as is the case in Washington state) or they at other times serve as a barrier to entry for many industries, thus preventing or reducing competition. Licensing requirements in this country today are nothing short of remarkable. ${ }^{9}$ Many local and state governments license businesses for no legitimate health or safety reasons. For example, tourist guides, funeral attendants, and florists are all sometimes licensed professionals even though there is no legitimate public health or safety reason for such laws. ${ }^{10}$

Local public schools provide yet another example of a situation where there is a government sponsored monopoly provider of public services. Like most monopoly providers, many public schools provide poor service to their consumers (parents and children), while diverting monopoly rents in the form of bloated salaries and benefits to the providers of education (bureaucrats and teachers' unions). Most Americans feel they have to send their children to public schools since they are taxed to pay for public schools even if they choose to send their children to private schools or to home-school them. ${ }^{11}$ The public school monopoly is especially objectionable because it interferes with parental control over the raising and education of ones own children. ${ }^{12}$

\footnotetext{
${ }^{9}$ Chip Mellor \& Dick Carpenter, Want Jobs? Cut Local Regulations, WALL StREET JouRnal, July 28, 2011, available at http://online.wsj.com/article/SB10001424052702304911104576443881925941712.html.

${ }^{10} \mathrm{Id}$.

${ }^{11}$ The public school monopoly is discussed further in a forthcoming working paper by Steven G. Calabresi and Abe Salander entitled "Religion and the Equal Protection Clause: Why School Vouchers are Constitutionally Required." ${ }^{12}$ Id.
} 
Ever since the New Deal, the U.S. Supreme Court has applied the very deferential rational basis test in reviewing the constitutionality of federal and state economic regulations including those that grant monopoly status. Such laws are rarely challenged and even more rarely struck down. We think this is a mistake. ${ }^{13}$ We think the post New Deal caselaw on economic liberties, epitomized by Williamson v. Lee Optical Co., is wrongly decided and that the right to be free from class legislation, monopolies, and grants of special privilege is deeply rooted in this nation's history and traditions. We therefore think this right is embodied in the Fourteenth Amendment to the U.S. Constitution and that it can only be trumped by just laws enacted for the good of the whole people. ${ }^{14}$ We think George Will is right when he denounces government licensing schemes because they "lack[] constitutional warrant and repudiate[] the nation's foundational philosophy" and because they require entrepreneurs to "approach government on bended knee to beg it to confer upon them a right—-the right to compete."15

We also agree with John Tomasi’s new book, Free Market Fairness, which argues that economic liberties are just as important to freedom as are all of the other liberties embraced by classical liberals. ${ }^{16}$ We think that this law review article helps to spell out the legal underpinnings and history of the economic liberties that Tomasi identifies, and we view our analysis and Tomasi's as being in harmony and as being mutually reinforcing. Tomasi defends economic liberty from the perspective of political philosophy to which we seek here to add the perspective of history and law.

\footnotetext{
${ }^{13}$ Steven G. Calabresi \& Julia Rickert, Originalism and Sex Discrimination, 90 TEX. L. REV. 1 (2011); Melissa Saunders, Equal Protection, Class Legislation, and Color-Blindness, 96 MiCH. L. REV. 245 (1997).

${ }^{14} 6$ Fed. Cas. 546, no. 3230 (C.C.E.D.Pa. 1823).

${ }^{15}$ George Will, Testing the Waters of Economic Liberty, WASH. POST, Dec. 18, 2011, available at http://patriotpost.us/opinion/george-will/2011/12/18/testing-the-waters-of-economic-liberty/.

${ }^{16}$ JOHN TOMASI, FREE MARKET FAIRNESS (2012).
} 
Part I of this paper discusses the English legal history with respect to government licensed monopolies in the Seventeenth Century and the landmark events for limiting the King's power to grant monopoles - the Case of Monopolies and Statute of Monopolies. Part I also discusses the spread of the English concern with government grants of monopoly to the American colonies, and it discusses the role monopolies in trade played in colonial America in building support for the American Revolution. Part II discusses the effort by some of the Framers of the U.S. Constitution to obtain an anti-monopoly clause in the federal Constitution, an effort which ultimately failed. Part II shows how anti-monopoly ideas infused themselves into the Supreme Court's early Contracts Clause caselaw and the central role they played in the emergence of the Fourteenth Amendment as a ban on class or caste based legislation. Part II also discusses the connection between the various federal antitrust laws and government-granted monopolies. Part III discusses the adoption of antimonopoly clauses in state constitutions, beginning at the Founding and continuing through the early twentieth century. Part III also considers the move toward general laws governing incorporation for corporations and away from special legislative charter grants. Part III also surveys how the monopoly concept came in some states to reflect a concern with private economic power, and it also surveys state cases which apply state antimonopoly provisions. We conclude with a few parting words about the decline in concern for the protection of economic liberty in modern American constitutional law.

\section{A BRIEF History: How MONOPOliEs CAME TO BE HATED}

\section{A. The English Experience with Monopolies}

The English hatred of monopolies dates back to the reigns of Queen Elizabeth I and King James I. Two principal events—one coming from the common law courts and the other coming from Parliament—show the strong disapproval of government monopolies in early Seventeenth 
Century England. The first such event is a case, Darcy v. Allen (commonly known as the Case of Monopolies), which was decided in 1601. In this case, a common law court reviewed a royal grant of trade privileges and struck down the grant as being void under the common law. ${ }^{17}$ The second key event is the passage in 1624 of the Statute of Monopolies, which was the result of years of pressure by the House of Commons to prohibit the King or Queen from granting the same kinds of monopoly privileges as those that had been struck down in Darcy. ${ }^{18}$ These two events mark a time when intellectuals and lawyers began to truly recognize the right of Englishmen to work for a living and to compete with each other without interference from government grants of special economic privilege. ${ }^{19}$

\section{Darcy v. Allen}

During Queen Elizabeth's very long reign she oftentimes found herself in need of more money than Parliament had appropriated for her to use. As a result, she sometimes tried to supplement her subsidy from Parliament by selling royal monopolies. ${ }^{20}$ This practice was criticized by some in Parliament because it imposed a burden on subjects in addition to the burden they already bore in paying taxes. A royal grant of monopoly privileges meant that subjects suffered a loss of jobs, since some people were shut out of their trades, and consumers had to pay higher prices since the existence of legal monopolies drove up the price of goods. ${ }^{21}$ For instance, in a speech at Parliament in 1571, Robert Bell said that "the People were galled by

\footnotetext{
${ }^{17} 77$ Eng. Rep. 1260 (K.B. 1603).

${ }^{18}$ An Act concerning Monopolies and Dispensations with Penal Laws, and the Forfeitures thereof (Statute of Monopolies), 21 Jam., c. 3 (1624).

${ }^{19}$ Timothy SANDEFUR, THE Right TO EARN A Living 17 (2010). (2005)

${ }^{20}$ Thomas B. Nachbar, Monopoly, Mercantilism, and the Politics of Regulation, 91 VA. L. Rev. 1313, 1328

${ }^{21}$ Id. at 1328.
} 
two means . .. . [B]y Licences a few only were enriched, and the multitude impoverished.”22 As Adam Smith later described in Wealth of Nations, the punishment for violating grants of monopoly privileges was sometimes severe. Smith wrote that:

Like the laws of Draco, these laws may be said to be all written in blood . . . the exporter of sheep, lamps, or rams, was for the first offence to forfeit all his goods for ever, to suffer a year's imprisonment, and then to have his left hand cut off in a market town upon a market day, to be there nailed up; and for the second offense to be adjudged a felon, and to suffer death accordingly. ${ }^{23}$

Queen Elizabeth's response to complaints about the monopolies she was granting was at first entirely dismissive. She thus said: "We are to let you understand, her Majesty's pleasure in that behalf that her Prerogative Royall may not be called in question for the valliditie of the letters patents.”24

Opposition in Parliament to exclusive trade privileges continued in 1597 when a note was sent to Queen Elizabeth I requesting that she stop the practice of granting royal monopolies. ${ }^{25}$ Parliament's note to the Queen gently requested, "her Highness['s] most gracious care and favour, in the repressing of sundry inconveniences and abuses practiced by Monopolies and Patents of priviledge." 26 In addition, at the end of the ninth parliament the Speaker mentioned the issue of monopolies in his closing speech, which was unusual because presentation of the Queen's subsidy customarily took place during the final speech. ${ }^{27}$ In response, Queen Elizabeth

\footnotetext{
${ }^{22}$ Id. (quoting Simonds D’EWES, A COMPLEAT JOURNAL OF THE Votes, SPEECHES AND DEBATES, BOth OF THE House OF LORDS AND HOUSE OF COMMONS Throughout THE WHOLE REIGN OF QuEEN ELIZABETH OF GLORIOUS MEMORY 158 (Scholarly Resources 1974) (1693)).

${ }^{23}$ ADAM SMITH, AN INQUiRY INTO THE NATURE AND CAUSES OF THE WEALTH OF NATIONS 700-01 (Edwin Cannan, ed., Modern Library 1994) (1776).

${ }^{24}$ Adam Mosoff, Rethinking the Development of Patents: An Intellectual History, 1550-1800, 52 HASTINGS L.J. 1255, 1264-65 (2001) (quoting Edward C. Walterscheid, The Early Evolution of the United States Patent Law: Antecedents (Part 2), 76 J. PAT. \& TRADEMARK OfF. SOC’Y 849, 863 (1994)).

${ }^{25}$ Thomas B. Nachbar, Monopoly, Mercantilism, and the Politics of Regulation, 91 VA. L. REV. 1313, 1329-30 (2005) (quoting SimONDS D’EWES, A COMPLEAT JOURNAL OF THE Votes, SPEECHES AND DEBATES, BOTH OF THE HOUSE OF LORDS AND HOUSE OF COMMONS THROUGHOUT THE WHOLE REIGN OF QUEEN ELIZABETH OF GLORIOUS MEMORY 553 (Scholarly Resources 1974) (1693)).

${ }^{26} I d$.

${ }^{27}$ Id. at 1329.
} 
asked Parliament to let her continue the practice. But, at the same time, the Queen seemed to acknowledge that Parliament had power to regulate with respect to her prerogative power to grant monopolies - a clear weakening of her earlier position:

$[\mathrm{H}] \mathrm{er}$ Majesty hoped that her dutiful and loving Subjects would not take away her Prerogative, which is the chiefest Flower in her Garden, and the principal and head Pearl in her Crown and Diadem; but that they will rather leave that to her Disposition. And as her Majesty hath proceeded to Trial of them already, so she promiseth to continue, that they shall all be examined, to abide the Trial and true Touchstone of the Law. ${ }^{28}$

However, it became clear that Queen Elizabeth had no intention of carrying through with her promise to regulate the distribution and functioning of royal monopolies, despite her apparent recognition that Parliament had power in this area. So, in 1601, the topic of royal power to grant monopolies was again heavily debated in Parliament, and as a result, a draft bill to outlaw royal monopolies was introduced. ${ }^{29}$ But before a decision was made with regard to the draft bill, Queen Elizabeth offered Parliament a compromise. Traditionally cases regarding the royal monopolies could only be heard by the Court of Star Chamber, a fortress of royal power in which the common law of England did not apply. Queen Elizabeth proposed as a compromise to both cancel some of the least popular monopolies she had granted and, most importantly, to allow new cases involving the legality of monopolies to be heard in a common law court. ${ }^{30}$

The result of this compromise was the famous 1603 case of Darcy v. Allen, often called The Case of the Monopolies. Interestingly, Darcy itself involved not a challenge to the legality of royal monopolies, but rather was brought by a monopoly-holder to protect his privilege. The suit was brought by Edward Darcy in 1602 who claimed that Thomas Allen infringed on his

\footnotetext{
${ }^{28} 4$ Parl. Hist. Eng. 420 (Feb. 9, 1598)); see also Chris Dent, “Generally Inconvenient”: The 1624 Statute of Monopolies as Political Compromise, 33 MeLB. U. L. REV. 415, 425-26 (2009).

${ }^{29}$ Thomas B. Nachbar, Monopoly, Mercantilism, and the Politics of Regulation, 91 VA. L. REV. 1313, 1331 (2005).

${ }^{30} I d$.
} 
monopoly right (through a royal patent granted by Queen Elizabeth) to produce, import, and sell all trading cards in England. The court held that the patent was void under the common law. ${ }^{31}$ Yet there was no published judicial opinion of the case, in the modern sense, because in seventeenth century England and for many years thereafter, English judges delivered their opinions in cases orally from the bench. ${ }^{32}$ And unless a private reporter wrote down and published what the judges said, the case law precedent would be lost.

Luckily, Sir Edward Coke, the most famous lawyer of his day, did write up a report on Darcy v. Allen, which has been very influential. ${ }^{33}$ Coke interestingly represented Darcy in the case since Coke was the Attorney General and was bound to defend the legality of the monopoly that was being challenged there. Coke's report, which was written an entire twelve years after the case was decided, describes the common law court's rationale as a strong statement about the importance of open and free trade. According to Coke’s report, the court struck down the royal monopoly because allowing people to work in their respective trades was not only beneficial for them, but was also necessary for the well-being of the whole country:

All Trades . . . which avoid idleness . . . and exercise men and youths in labor for the maintenance of them and their Families, and for the increase of their livings, to serve the Queen if need be were profitable for the Commonwealth; and therefore the grant to the Plaintiff to have the sole making of them is against the Common Law, and the benefit and liberty of the subject. ${ }^{34}$

And while the financial benefits were important, Coke's report suggests the case was as much a statement about the negative consequences of exclusive trade privileges as it was about the

\footnotetext{
${ }^{31}$ Darcy v. Allen, 11 Co. Rep. 84b, 77 Eng. Rep. 1260 (K.B. 1603).

32 Jacob I. Corré, The Argument, Decision, and Reports of Darcy v. Allen, 45 EMORY L.J. 1261, 1325 (1996).

${ }^{33}$ See id. at 1262 (describing Coke's report as "exceptionally durable”). As Corré points out, Darcy v. Allen has been cited in modern English cases. Id. (citing Nyali, Ltd. v. Attorney Gen., (1956) 1 Q.B. 1, (1955) 1 All ER 646). As will be discussed later herein, Darcy was also very influential in the pleadings in The Slaughterhouse Cases. 83 U.S. 36 (1872). Although Darcy involved the grant of monopoly by the state, it has also proved influential in the antitrust context in the United States. Jacob I. Corré, The Argument, Decision, and Reports of Darcy v. Allen, 45 EMORY L.J. 1261, 1262 (1996) (citing City of Columbia v. Omni Outdoor Adver., Inc., 499 U.S. 365, 386 (1991) (Stevens, J., dissenting)).

${ }^{34}$ Darcy v. Allen, 11 Co. Rep. 84b, 86a 77 Eng. Rep. 1260 (K.B. 1603).
} 
individual right to economic liberty. In fact, it was critical to have the freedom to pursue one's livelihood_- "That every mans Trade doth maintains his life, and therefore he ought not to be deprived or dispossessed of it, no more than of his life."35

Coke's report of the case discussed the many problems with monopolies and in particular the ways in which monopolies diminish wealth. First, monopolies serve only the interests of those who are granted the monopoly:

The sole Trade of any Mechanical Artifice, or any other Monopoly is not only a damage and prejudice to those who exercise the same Trade, but also to all other subjects, for the end of all these Monopolies is for the private gain of the Patentees; and although provisions and cautions be added to moderate them; yet . .. it is meer folly to think that there is any measure in mischief or wickedness. ${ }^{36}$

More specifically, Coke discusses the effects trade privileges have on people who wish to enter a trade but who are prohibited from doing so because a royal monopoly gave an exclusive right to practice the trade to someone else:

This [leads] to the impoverishing of divers Artificers and others, who before by labor of their hands in their Art or Trade had kept themselves and their families, who now of necessity shall be constrained to live in idlenesse and beggary. ${ }^{37}$

Further, but perhaps secondarily in Coke's mind and for others during the era, monopolies hurt the entire public because monopolies lead to higher prices and poorer quality goods and services:

That the price of the said commodity shall be raised, for he who hath the sole selling of any commodity, may make the price as he pleaseth. . . That after a Monopoly [has been] granted, the Commodity is not so good and merchantable as it was before; for the patentee having the sole trade, regardeth only his private, and not the publicke weale. ${ }^{38}$

It is important to note that Coke's report in the Case of the Monopolies has been challenged by some scholars who accuse Coke of exaggerating the free trade stance of the

\footnotetext{
${ }^{35} \mathrm{Id}$. at 87 a (emphasis added).

${ }^{36} I d$. at $86 \mathrm{~b}$.

${ }^{37} \mathrm{Id}$.

${ }^{38} \mathrm{Id}$.
} 
common law. ${ }^{39}$ The primary evidence that Coke's report of the case was an exaggeration is that Kings and Queens continued to issue monopoly royal patents for many years after Darcy v. Allen was decided. Queen Elizabeth died the year Darcy was decided and King James I took the throne. James I was not nearly as well-liked in Parliament as Queen Elizabeth had been, which did not bode well for his ability to receive subsidies. ${ }^{40}$ Unlike Queen Elizabeth, King James I pursued a more aggressive and costly foreign policy, and he failed totally to exercise fiscal conservatism, spending lots of money on entertaining and on promoting his favorites who tended to be handsome young men. ${ }^{41}$ Because of King James I's extensive military engagements, his inability to control spending, and his poor relationship with Parliament, the new King found himself extensively using his powers to issue royal patents in order to raise money. ${ }^{42}$

Since King James I continued to issue monopoly royal trade privileges, the House of Commons again pushed for adoption of a law to prohibit the King from granting monopolies. Although King James resisted, some signs of change began to appear. For example, in 1610 James issued his Book of Bounty, in which he stated that exclusive trade privileges were contrary to the common law and his own policies, that he intended to discontinue the privileges, and that he promised not to entertain any new suitors regarding monopolies. ${ }^{43}$

Despite the Book of Bounty, however, James continued to issue monopolies. For example, in 1615 Sir Edward Coke, who was by then the Lord Chief Justice of England, struck down a guild incorporated under a charter, relying on Darcy. ${ }^{44}$ This apparently came as no

\footnotetext{
${ }^{39}$ See, e.g., Jacob I. Corré, The Argument, Decision, and Reports of Darcy v. Allen, 45 EMORY L.J. 1261, 1325 (1996); Thomas B. Nachbar, Monopoly, Mercantilism, and the Politics of Regulation, 91 VA. L. ReV. 1313, 1332 (2005).

${ }^{40}$ Id. at $1342-43$.

${ }^{41} I d$.

${ }^{42}$ Id. at $1344-45$.

43 Jacob I. Corré, The Argument, Decision, and Reports of Darcy v. Allen, 45 EMORY L.J. 1261, 1324 (1996); Thomas B. Nachbar, Monopoly, Mercantilism, and the Politics of Regulation, 91 VA. L. REV. 1313, 1345 (2005). ${ }^{44}$ The Case of the Tailors of Ipswich, 12 Jam. 1 (1614).
} 
surprise to Parliament. As one member of Parliament quipped, "Yet, as in a Garden, clean weeded, Weeds next Year; so here, by new Patents, Proclamation.”45 As a result, King James’s relationship with Parliament continued to worsen, and the King dissolved Parliament whenever there was a disagreement. Not surprisingly, Parliament decided in 1614 to discontinue King James's subsidy until resolutions regarding the granting of monopolies and impositions (royal import duties imposed in addition to duties on tonnage and poundage) were reached. ${ }^{46}$

These events after Darcy v. Allen was decided raise a question about what we should make of Sir Edward Coke's report of the famous case. At least one scholar argues that at the time Coke published his report of Darcy v. Allen in 1615, his view on the royal patent power was no longer as controversial, and perhaps his views on the court's rationale evolved as a result of events in the twelve years between the case and his published report. ${ }^{47}$ Further, even accepting as true that Coke's report of the Darcy v. Allen was exaggerated (which cannot be known for sure since there is no official published opinion), Sir Edward Coke’s report has been described as “exceptionally durable” and has been cited as good law for centuries in both England and the United States, including in some modern case law. ${ }^{48}$ Sir Edward Coke’s views on monopolies were also not unique to him-similar arguments were made at the same time in the House of Commons. As previously mentioned, Robert Bell said in Parliament at this time that "the People were galled by two means .... [B]y Licences a few only were enriched, and the multitude

\footnotetext{
45 Thomas B. Nachbar, Monopoly, Mercantilism, and the Politics of Regulation, 91 VA. L. REV. 1313 , n. 148 (2005).

${ }^{46}$ Id. at $1345-46$.

${ }^{47}$ Id. at $1266,1324-25$.

48 Jacob I. Corré, The Argument, Decision, and Reports of Darcy v. Allen, 45 EMORY L.J. 1261, 1325 (1996) (citing Nyali, Ltd. v. Attorney Gen., (1956) 1 Q.B. 1, (1955) 1 All ER 646). As will be discussed later herein, Darcy was also extremely influential in the pleadings in The Slaughterhouse Cases. Id. (citing Slaughter-House Cases, 83 U.S. 36 (1872)). Although Darcy involved the grant of monopoly by the state, it has also proved influential in the antitrust context in the United States. Id. (citing City of Columbia v. Omni Outdoor Advertising, Inc., 499 U.S. 365, 386 (1991) (Stevens, J., dissenting)).
} 
impoverished." ${ }^{49}$ Thus, even if Coke’s report of the case itself was an exaggeration, Coke's rationale and reasoning were subsequently widely agreed to. As will be discussed later herein, it was Sir Edward Coke's report of the case of the monopolies-and no other report-that influenced some of the Founding Fathers, the Anti-Federalists, and the American state governments when they adopted or amended their own constitutions. Thus, even if Coke's views were idiosyncratic or wrong about the law of England, the Framers of the U.S. Constitution took them as being true. Founding generation Americans then might very well have believed there was an ancient English constitutional right to be free of monopolies.

\section{The Statute of Monopolies}

By 1614 the relationship between the King and Parliament had significantly deteriorated, an important precursor to the English Revolution which would begin in the 1640's. King James I abused the royal prerogative and dissolved his first two Parliaments, leading Parliament to refuse to give James a royal subsidy. Without such a subsidy, the King was forced to find other sources of revenue. He turned in large part to the granting of monopoly royal trade privileges, but in the process the entire system of the granting of such privileges broke down:

Patents were granted, routinely revoked . . . and re-issued to someone else. Eventually, revocation became so common that patents being issued included language permitting revocation by vote of the Privy Council. Increasingly desperate for revenue, James granted broad supervisory control over whole industries and with it broad powers to search and arrest infringers. These powers were predictably subject to frequent and profound abuse by the patentees, who were commonly unpopular favorites of James . . . further fomenting public scorn for both the monopolies and the monopolists. The administrative mechanism for controlling the patents having broken down, their use was completely unmanaged. The patents were economically burdensome and politically unpopular, but their

49 "The People were galled by two means .... [B]y Licences a few only were enriched, and the multitude impoverished.” Thomas B. Nachbar, Monopoly, Mercantilism, and the Politics of Regulation, 91 VA. L. REV. 1313, 1328 (2005) (quoting SimONDS D’EWES, A COMPLEAT JOURNAL OF THE VOTES, SPEECHES AND DEBATES, BOTH OF

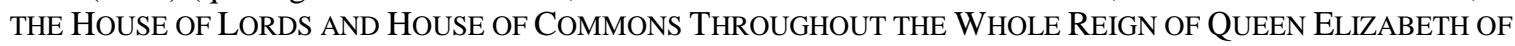
GLORIOUS MEMORY 158 (Scholarly Resources 1974) (1693)). 
use was so poorly administered that James received very little of the economic rents they generated. ${ }^{50}$

King James I called his third Parliament in 1621, at which point the issue of royally granted monopolies was the first item on the agenda in the House of Commons. This was in part attributed to a severe economic depression at that time, even though the monopolies themselves did not appear to be the primary cause of the depression. ${ }^{51}$ The House of Commons established a Committee of Grievances, with Sir Edward Coke who was by then a Member of Parliament as chairman. Coke had been fired as Lord Chief Justice of England by King James for his unwillingness to decide legal cases in the way the King wanted him to do. He entered Parliament as a foe to the King. By 1621, Coke was one of the most outspoken critics of royally granted monopolies, and a draft bill banning monopolies was quickly reported in Parliament. ${ }^{52}$ However, the draft bill banning monopolies did not pass the House of Lords at that time because there was still concern among the Lords that the bill would be too much of a constraint on the royal prerogative. In an effort to appease the House of Commons, King James issued yet another proclamation cancelling some patents and submitting others to common law courts. ${ }^{53}$ He also later established a committee by royal proclamation which was to hear and to address grievances regarding monopolies. ${ }^{54}$

\footnotetext{
${ }^{50} \mathrm{Id}$. at 1346 (citing HAROLD G. FOX, MONOPOLIES AND PATENTS: A STUDY OF THE HiSTORY AND FUTURE OF the Patent Monopoly 102 \& n.45 (1947); William Hyde Price, The English Patents of Monopoly 29, 3132, \& n.4 (1913)).

${ }^{51}$ Chris Dent, "Generally Inconvenient”: The 1624 Statute of Monopolies as Political Compromise, 33 MELB. U. L. REV. 415, 430 (2009).

52 Thomas B. Nachbar, Monopoly, Mercantilism, and the Politics of Regulation, 91 VA. L. REV. 1313, 1346 (2005).

${ }^{53}$ Id. at 1348.

${ }^{54}$ Chris Dent, “Generally Inconvenient”: The 1624 Statute of Monopolies as Political Compromise, 33 MELB. U. L. REV. 415, n.163 (2009).
} 
Between 1621 and 1624, debate over foreign policy consumed much of Parliament’s time. ${ }^{55}$ However, eventually a bill which became the Statute of Monopolies passed the House of Commons with language that was largely the same as that in the 1621 bill. ${ }^{56}$ When the bill reached the House of Lords, the Lords proposed a number of exceptions to the general prohibition on monopolies, such as exceptions for the granting of patents and for the chartering of corporations. ${ }^{57}$ Sir Edward Coke did not ultimately object to the exception for chartering corporations, since he did not think the Statute of Monopolies applied to them. ${ }^{58}$ Further, Parliament wanted to maintain full employment, which the guilds (also exempted from the Statute of Monopolies) and corporations were both thought to protect. ${ }^{59}$ Parliament was beholden to the guilds, and the guilds exerted an enormous amount of power at this time. ${ }^{60}$ For example, during the same term that Parliament passed the Statute of Monopolies, it also passed a seemingly conflicting statute which permitted only free members of the Cheesemongers and Tallow-chandlers guilds to purchase cheese and butter for resale in London. ${ }^{61}$ It is also reported that in order for the Statute of Monopolies to pass the House of Lords, it was necessary to alter the act to include exceptions for glass making and for alum mines. ${ }^{62}$

Guilds were not necessarily monopolies. Historically, guilds had been fraternal associations, which in this context were joined together by a shared craft or trade. However, by obtaining patents or charters within the city in which they operated—which they generally were

\footnotetext{
${ }^{55}$ James's proposed for his son to Charles to marry Infanta Maria of Spain in order to create an alliance, and once that failed, there was anticipation of war with Spain which consumed Parliament's time. Thomas B. Nachbar, Monopoly, Mercantilism, and the Politics of Regulation, 91 VA. L. REV. 1313, 1348-49 (2005).

${ }^{56}$ Id. at 1349.

${ }^{57}$ Id. at 1350 .

${ }^{58} I d$.

${ }^{59}$ Id. (“[I]t has been argued that the 'official protection' of companies throughout the Stuart period stemmed 'directly from an employment policy [despite bearing] the superficial marks of being concerned solely with private or strategic interests.”)

${ }^{60}$ Id.

${ }^{61} \mathrm{Id}$. at 1350 .

${ }^{62}$ Chris Dent, "Generally Inconvenient”: The 1624 Statute of Monopolies as Political Compromise, 33 MELB. U. L. REV. 415, 450 (2009).
} 
able to do-the guilds often gained monopoly control over their respective craft or trade. Because English guilds held more sway with Parliament than with the Crown, the guilds sought support from Parliament to protect them from the royally granted monopolies, which sometimes conflicted with their control of a particular market. ${ }^{63}$

The Statute of Monopolies, as incorporated by the House of Lords and approved by the House of Commons in 1624, is strongly worded and is broad in scope, reaching all types of royally granted monopolies. As New York Chancellor James Kent later described the law, it was the “'Magna Charta of British Industry,' because it 'contained a noble principle, and secured to every subject unlimited freedom of action, provided he did not injury to others, nor violated statute law. ${ }^{64}$ In Section one it provides that:

[A]ll Monopolies, and all Commissions, Grants, Licences, Charters and Letters Patents heretofore made or granted, or hereafter to be made or granted, to any Person or Persons, Bodies Politick or Corporate whatsoever, of or for the sole Buying, Selling, Making, Working or Using of any Thing within this Realm, or the Dominion of Wales ... or of any other Monopolies, or of Power, Liberty or Faculty, to dispense with any others, or to give Licence or Toleration to do, use or exercise any Thing against the Tenor or Purport of any Law or Statute ... and all Proclamations, Inhibitions, Restraints, Warrants of Assistants, and all other Matters and Things whatsoever, any way tending to the Instituting, Erecting, Strengthening, Furthering or Countenancing of the same or any of them . . . are altogether contrary to the Laws of this Realm, and so are and shall be utterly void and of none Effect, and in no wise to be put in Use or Execution. ${ }^{65}$

Section two makes it clear that litigation involving monopolies was subject to trial in the common law courts. ${ }^{66}$ Sections five and six of the Statute contain exceptions for invention patents, which were subject to a time limit:

${ }^{63}$ Thomas B. Nachbar, Monopoly, Mercantilism, and the Politics of Regulation, 91 VA. L. REv. 1313, 1350, 1355 (2005).

${ }^{64}$ TIMOTHY SANDEFUR, THE Right TO EARN A LiVING 20 (2010).

${ }^{65}$ An Act concerning Monopolies and Dispensations with Penal Laws, and the Forfeitures thereof (Statute of Monopolies), 21 Jam., c. 3 (1624) § 1 (emphasis added).

${ }^{66}$ Id. § 2 (“[A]ll monopolies . . . commissions, grants, licences, charters, letters patents, proclamations, inhibitions, restraints, warrants of assistance ... shall be for ever hereafter examined, heard, tried, and determined, by and according to the common laws of this realm”). 
[A]ny Declaration before-mentioned shall not extend to any Letters Patents and Grants of Privilege for the Term of fourteen Years or under, hereafter to be made, of the sole Working or Making of any manner of new Manufactures within this Realm, to the true and first Inventor and Inventors of such Manufactures, which others at the Time of Making such Letters Patents and Grants shall not use. ${ }^{67}$

Interestingly, Section seven exempts grants of monopoly privileges by Parliament:

[T]his act or anything therein contained shall not in any wise extend or be prejudicial to any grant or privilege, power, or authority whatsoever heretofore made, granted, allowed, or confirmed by any act of parliament now in force, so long as the same shall so continue in force. ${ }^{68}$

As previously mentioned, Sections nine through fourteen provide exceptions for corporations and specific patents. ${ }^{69}$

James's response to Parliament's passage of the Statute of Monopolies was predictably negative:

'Touching my Patents in general, I am grieved that you have called them in and condemned them upon so short examination. I confess I might have passed some upon false suggestion and wrong information, but you are not to recall them before they be examined by the judges .... . Therefore I advise you to be careful, that you have a good ground before you call for your patents, that you do not defraud patentees .... I I say to you when you judge of patents, hear patiently, say not presently, it is against the law, for patents are not to be judged unlawful by you. ${ }^{70}$

Thus, again James questioned Parliament's authority to enact the Statute, although he "begrudgingly" assented to it. ${ }^{71}$ However, given James’s views it is perhaps unsurprising that despite the Statute's sweeping language, monopoly royal trade privileges continued to be granted

\footnotetext{
${ }^{67} I d$. §§ 5-6 (“' $\left.\mathrm{A}\right]$ ny declaration before mentioned shall not extend to any letters patents and grants of privilege for the term of fourteen years or under, hereafter to be made, of the sole working or making of any manner of new manufactures within this realm”).

${ }^{68} I d . \S 7$.

${ }^{69} I d$. §§ 9-14. As discussed elsewhere in this paper, some of these exceptions have been attributed to the influence of special interests on Parliament. See Chris Dent, "Generally Inconvenient": The 1624 Statute of Monopolies as Political Compromise, 33 MELB. U. L. REV. 415, 448-49 (2009).

${ }^{70}$ Adam Mosoff, Rethinking the Development of Patents: An Intellectual History, 1550-1800, 52 HASTINGS L.J. 1255, 1271-72 (2001) (quoting Edward C. Walterscheid, The Early Evolution of the United States Patent Law: Antecedents (Part 2), 76 J. PAT. \& TRADEMARK OFF. SOC’Y 849, 873 (1994)).

${ }^{71}$ Id. at 1271.
} 
well past King James I's reign (which ended with his death in 1625) and through the reign of King Charles I despite the fact King James I did not veto the Statute of Monopolies. ${ }^{72}$

Parliament continued to complain about and to protest against royal monopolies after the adoption of the Statute of Monopolies. For example, during the Long Parliament, which lasted from 1640 until 1648, Parliament could only be dissolved by agreement of its members. Monopolies were one of the main issues that confronted the Long Parliament, and one of the most famous statements criticizing royal monopolies was made at this time:

They are a nest of wasps-a swarm of vermin which have overcrept the land. Like the frogs of Egypt they have gotten possession of our dwellings, and we have scarce a room free from them. They sup in our cup; they dip in our dish; they sit by our fire. We find them in the dye-fat, wash-bowl, and powdering-tub. They share with the butler in his box. They will not bait us a pin. We may not buy our clothes without their brokage. These are the leeches that have sucked the commonwealth so hard that it is almost hectical. ${ }^{73}$

Eventually, Parliament was successful in cancelling some monopolies and in abolishing the Court of Star Chamber in 1641, the primary court that had enforced and protected the royally granted monopoly privileges. ${ }^{74}$ The Statute of Monopolies came eventually to be seen as being a declaration by Parliament of its authority to legislate against royally granted monopolies and as expressing Parliament's strong support for the common law courts. ${ }^{75}$ Indeed, Parliament's exercise of power in opposing royal monopolies eventually led to the exertions of parliamentary power which culminated in the English Civil War and the Glorious Revolution of 1688 which took place just decades later. Parliament's power to bind the King by making statutory law was

\footnotetext{
${ }^{72}$ Thomas B. Nachbar, Monopoly, Mercantilism, and the Politics of Regulation, 91 VA. L. REV. 1313, 1353 (2005)

${ }^{73}$ Slaughter-House Cases, 83 U.S. (16 Wall.) 36 (1872) (quoting the Speech of Sir John Culpepper).

${ }^{74}$ Michael Conant, Antimonopoly Tradition Under the Ninth and Fourteenth Amendments: Slaughter-House Cases Re-Examined, 31 EMORY L.J. 785, 796 (1982).

${ }^{75}$ Adam Mosoff, Rethinking the Development of Patents: An Intellectual History, 1550-1800, 52 HASTINGS L.J. 1255, 1272 (2001) (describing the Statute of Monopolies as "an incredible assertion of parliamentarian order and rule by common law.”).
} 
confirmed for all time as a result of the adoption of the English Bill of Rights of 1689, which ended the King's claim that he could ignore or alter statutory law. ${ }^{76}$

In some sense the struggle over the Statute of Monopolies was as much a struggle over political power as it was a statement about free trade since Section seven of the Statute made monopolies issued by the Crown illegal but such monopolies when issued by Parliament were still permitted. ${ }^{77}$ King James I may only have assented to the Statute of Monopolies because England by then was at war with Spain, making the King more willing to concede power to Parliament in order to ensure funding for the impending war. In any event, the Statute received the royal assent and so it became part of the supreme law of England.

The debate over monopolies should also be viewed during the late 1620's in light of the efforts of King James I's son, King Charles I, to tax Englishmen without parliamentary approval. King Charles I's preferred way of doing this was to arrest wealthy individuals and then say he would only release them in exchange for a forced loan. Parliament, led by Sir Edward Coke, was outraged. As a result, a document called the Petition of Right was drafted and presented to Charles I with all of Parliament attending, and Charles reluctantly agreed to the Petition of Right. The belief of colonial Americans that they could not be taxed by an English parliament in which they were not represented dates back in part to Parliament's successful efforts in the 1620's to stop monopolies and to prevent the King from taxing his subjects without Parliament's consent.

While the Statute of Monopolies was a big accomplishment from a constitutional perspective, it had some serious shortcomings because of its various exceptions and because of the fact that it reserved the power to grant monopolies to Parliament. Why did the Statute pass in the form in which it did? First, as part of the lawmaking process, members of Parliament had to

\footnotetext{
${ }^{76}$ Thomas B. Nachbar, Monopoly, Mercantilism, and the Politics of Regulation, 91 VA. L. REV. 1313, 1353-54 (2005).

${ }^{77} I d$. at 1354 .
} 
make compromises for the sake of political expediency. This necessitated the inclusion of various exceptions for politically powerful special interest groups, such as the various guilds. The guilds were leading advocates of the Statute of Monopolies because of the power it took away from the Crown, and they thus had a huge influence on the drafting of the Statute. The Guilds obviously did not support the Statute of Monopolies because it stood for free trade, but because the Statute would help them economically by protecting the guilds from royal monopolists. ${ }^{78}$ Second, the theoretical underpinnings for the benefits of free trade had not yet been expounded by Adam Smith and other modern economists, and England was dominated by mercantilism at the time the Statute of Monopolies was enacted. ${ }^{79}$ Adam Smith's The Wealth of Nations - the fundamental work in classical economics — was not published until 1776, over one hundred and fifty years after the Statute of Monopolies was enacted. Britain's free trade era did not begin until the mid-nineteenth century.

Nonetheless, the negative effects of monopolies were recognized in the early Seventeenth Century, and monopolies were in fact limited in post-Revolutionary England as compared to what the situation had been under the Tudors and Stuarts. ${ }^{80}$ The limits set on monopolies both in the common law case law such as Darcy and in the Statute of Monopolies show an awareness of the costs monopolies impose. This concern with the evils of monopoly travelled with Englishmen when they crossed the Atlantic Ocean to the settle in the New World.

\section{B. Colonial America}

The North American colonists generally considered themselves Englishmen, and they thus thought that English statutes and common law rights and privileges should extend to them as they had applied to their English ancestors. In real life, however, this often did not happen,

\footnotetext{
${ }^{78} I d$. at 1350, 1355.

${ }^{79} \mathrm{Id}$. at 1358 .

${ }^{80}$ Id. at1361.
} 
which was one of the many grievances expressed by the colonists around the time of the writing of the Declaration of Independence:

[T] he respective colonies are entitled to the common law of England . . . [and] they are entitled to the benefit of such English statutes as existed at the time of their colonization; and which they have, by experience, respectively found to be applicable to their several and local circumstances. ${ }^{81}$

In practice, English statutes generally had to specify that they applied to the colonies in order for the courts to find that they did so. ${ }^{82}$ As for application of the common law to the colonists, matters were complicated by the fact that the colonies' interpretation of what was the "common law” did not always correspond to England's, and in any event, the common law in the North American colonies varied according to local circumstances. Moreover, although some language in the thirteen colonial charters suggested that the common law of England extended to the North American colonies, it is unlikely that the King's lawyers who drafted the charters meant to extend full common law rights to the colonies. ${ }^{83}$

The Statute of Monopolies did not state explicitly that it extended to the colonies, so it did not apply, and common law precedents were of questionable application as well. ${ }^{84}$ As a result, the colonies enacted their own versions of the Statute of Monopolies in order to both grant patents for economic development purposes and to place restrictions on when patents could be granted. For example, Massachusetts’s 1641 Body of Liberty provided that, "No monopolies shall be granted or allowed amongst us, but of such new Inventions that are profitable to the Countrie, and that for a short time. ${ }^{85}$ Connecticut passed a similar law in $1672 .{ }^{86}$ Compared to

\footnotetext{
${ }^{81} 1$ JOURNALS OF THE CONTINENTAL CONGRESS 1774-1789 63, 69 (Worthington Chauncy Ford ed., 1904).

${ }^{82}$ Edward C. Walterscheid, Understanding The Copyright Act of 1790: The Issue of Common Law Copyright in America and the Modern Interpretation of the Copyright Power, 53 J. COPYRIGHT SOC’Y U.S.A. 313, 320 (2006).

${ }^{83} \mathrm{Id}$. at 322.

${ }^{84} \mathrm{Id}$. at 323.

${ }^{85}$ Oren Bracha, The Commodification of Patents 1600-1836: How Patents Became Rights and Why We Should Care, 38 LOY. L.A. L. REV. 177, 214 (2004) (quoting The Body of Liberties of 1641; A Coppie of the Liberties of the
} 
the Statute of Monopolies, these acts have been described as "mainly declaratory" and the text of these provisions were much less comprehensive. ${ }^{87}$ The assembly was generally left to determine on a case by case basis whether to grant a patent and under what terms. ${ }^{88}$

It is essential to note that, if it were not for the Crown's ability to grant royal charters, the colonies themselves would not have existed. All of the original thirteen colonies were established through the grant of royal charters, by which the King established and empowered their respective governments. However, it is the language in the charters which would later be relied on by the colonists as their relationship with England deteriorated. For instance, Virginia's charter of 1611-12 established an assembly to meet four times per year to create laws "So always, as the same be not contrary to our Laws and Statutes of this our Realm of England . . . .89 Colonial charters were similarly written in the other North American colonies.

On this point, it is important to recognize the influence of Sir Edward Coke, who may be thought of as a hero for the colonies, especially the Puritans who settled in Massachusetts and Connecticut. Discussing the colonists' reliance on Coke for their understanding of the English common law, Theodore Plunckett wrote in a 1926 law review article that the common law was the "palladium of their civil liberties." 90 Coke proclaimed in Bonham's Case that the common law governed parliamentary acts, ${ }^{91}$ and the colonists repeatedly relied on Coke's declaration in Bonham's Case to argue that the common law could be used by the colonies to oppose British

\footnotetext{
Massachusets Colonie in New England, in THE COLONIAL LAWS OF MASSACHUSETTS, reprinted from the edition of 1660 with the supplement to 1672, at 33, 34-35, para. 9 (Boston 1890)).

${ }^{86}$ Id.

${ }^{87} I d$. at 215.

${ }^{88} I d$.

${ }^{89}$ Edward C. Walterscheid, Understanding the Copyright Act of 1790: The Issue of Common Law Copyright in America and the Modern Interpretation of the Copyright Power, 53 J. COPYRIGHT SoC’Y U.S.A. 313, 322 (1994).

90 Theodore F.T. Plunckett, Bonham's Case and Judicial Review, 40 HARV. L. REV. 30-70 (1926), reprinted in LAW, LiBERTY, AND PARLIAMENT: SELECTED ESSAYS ON THE WritingS OF SiR EDWARD COKE 179 (Allen D. Boyer, ed., Liberty Fund, 2004).

${ }^{91}$ Bernard H. Siegan, Protecting Economic Liberties, 6 CHAP. L. REV. 43, 50 (2003).
} 
regulations. $^{92}$ For example, the Massachusetts colony relied directly on Coke when King James II abrogated their original colonial charter in 1684 and attempted to consolidate all the New England colonies along with the colonies of New York and New Jersey in a so-called Dominion of New England. This event "provoked an outspoken claim [of] independence” and Bostonians were said to "hold forth a law book, \& quote the Authority of the Lord Cook to Justifie their setting up for themselves; pleading the possession of 60 years against the right of the Crown.”93 Sir Edward Coke's name and authority were also used by James Otis in Paxton's Case, challenging the writs of assistance which provided general search warrants often in customs cases. In fact, it is fair to say that Otis's entire argument in Paxton's Case relied upon Coke and Bonham's Case!

Another example of the hold that Sir Edward Coke had on the legal thinking of colonial Americans came with the controversy over the Stamp Act of 1765. This Act taxed the colonists without their consent, which elicited the complaint that the Act "violated 'Magna Carta and the natural rights of Englishmen, and therefore[,] according to Lord Coke[, was] null and void.’,94 Sam Adams expressed a similar view when he said that "whether Lord Coke has expressed it or not ... an act of parliament made against Magna Carta in violation of its essential parties, is

\footnotetext{
${ }^{92}$ See, e.g., Frederick Mark Gedicks, An Originalist Defense of Substantive Due Process: Magna Carta, Higher-Law Constitutionalism, and the Fifth Amendment, 58 EMORY L.J. 585, 668 (2009) (“Coke’s higher law constitutionalism was deployed by the American colonists in their revolutionary struggle against Britain and incorporated into their constitutional thinking, as evidenced by their revolutionary rhetoric, their conceptualization of their new state constitutions as primarily frames of government that recognized but did not create fundamental rights, and their conflict over the lack of a bill of rights in the federal Constitution”); Bernard H. Siegan, Protecting Economic Liberties, 6 CHAP. L. REV. 43, 50 (2003) ("The American colonists often cited Coke as proclaiming the supremacy of the common law, and many political leaders invoked Coke in opposition to regulation.”)

${ }^{93}$ Theodore F.T. Plunckett, Bonham's Case and Judicial Review, 40 HARV. L. REV. 30-70 (1926), reprinted in LAW, LiBERTY, AND PARLIAMENT: SELECTED ESSAYS ON THE WRITINGS OF SiR EDWARD COKE 179 (Allen D. Boyer, ed., Liberty Fund, 2004) (citing "An Account of the Colonys and Provinces of New England in general, More particularly of that of the Massachusetts").

${ }^{94}$ Bernard H. Siegan, Protecting Economic Liberties, 6 CHAP. L. REV. 43, 50 (2003) (quoting Robert E. Riggs, Substantive Due Process in 1791, 1990 WIS. L. REV. 941, 970).
} 
void." ${ }^{95}$ As the royal Governor of Massachusetts, Thomas Hutchinson, complained, the colonists took "advantage of a maxim they find in Lord Coke that an Act of Parliament against Magna Carta or the peculiar rights of Englishmen is ipso facto void." ${ }^{96}$ In addition to relying on Bonham's Case, when John Adams, writing under the pseudonym "Novanglus" in 1774 asserted that Parliament had no authority over the colonies and that each was a separate realm under the King with its own independent legislature, he started his analysis with an argument from Coke' s Institutes. ${ }^{97}$

Thus, the American colonists, relying in part on Coke, believed that all the constitutional protections of Englishmen applied to them-including the protections conferred by the Statute of Monopolies and by Darcy v. Allen. ${ }^{98}$ For example, William Penn, the founder of the Province of Pennsylvania and a proponent of the idea that the rights of Englishmen extended to those in the colonies, ${ }^{99}$ wrote about the evil of monopolies and the harm they caused. In a section of a 1687 pamphlet called The Excellent Priviledge of Liberty \& Property Being the Birth-Right of the Free-Born Subjects of England, William Penn summarized the Statute of Monopolies and Darcy v. Allen, writing that, "Generally all Monopolies are against the great charter because they are against the Liberty and Freedom of the Subject, and against the Law of the Land.”100 Thus, Thomas Barnes is quite right when he says, "Beg the question as to what extent Coke fell in

\footnotetext{
95 Thomas G. Barnes, Introduction to Coke on Littleton, reprinted in LAW, LIBERTY, AND PARLIAMENT: SELECTED ESSAYS ON THE WriTingS OF SIR EDWARD COKE 25 (Allen D. Boyer, ed., Liberty Fund, 2004) (quoting H.T. COLBOURN, THE LAMP OF EXPERIENCE 65 (1926)).

96 Theodore F.T. Plunckett, Bonham's Case and Judicial Review, 40 HARV. L. REV. 30-70 (1926), reprinted in LAW, LiBERTY, AND PARLIAMENT: SELECTED ESSAYS ON THE Writings OF SiR EdWARd CoKE 179 (Allen D. Boyer, ed., Liberty Fund, 2004).

${ }^{97}$ Thomas G. Barnes, Introduction to Coke on Littleton, reprinted in LAW, LIBERTY, AND PARLIAMENT: SELECTED ESSAYS ON THE Writings OF SIR EDWARD COKE 25 (Allen D. Boyer, ed., Liberty Fund, 2004)

${ }^{98}$ Michael Conant, Antimonopoly Tradition Under the Ninth and Fourteenth Amendments: Slaughter-House Cases Re-Examined, 31 EMORY L.J. 785, 799 (1982).

${ }^{99}$ Penn drafted the Frame of Government of Pennsylvania in 1682, which safeguarded the rights of Englishmen.

${ }^{100}$ Michael Conant, Antimonopoly Tradition Under the Ninth and Fourteenth Amendments: Slaughter-House Cases Re-Examined, 31 EMORY L.J. 785, 798 (1982) (quoting WILliAM PENN, ThE EXCELLENT PRIVILEGE OF LiBERTY \& PROPERTY BeING THE BIRTH-Right OF THE FREE-BORN SuBJECTS OF ENGLAND (1687), reprinted in A. HOWARD, The RoAd From RunNYMEdE: MAGNA CARTA AND CONSTITUTIONALISM IN AMERICA 621 (1968)).
} 
behind Citizen Sam—scores of others of our Founding Fathers had no doubt which side he was on and none questioned the magnitude of the aid he gave them." 101

England's continued practice of issuing monopolies helped directly in causing the American Revolution. England enacted an extensive set of laws which granted English merchants monopolies in colonial trade for a variety of markets-from manufactured goods to all kinds of raw materials. By the late eighteenth century, black markets arose in the colonies as a response to England's mercantilist trade policy. As a result, the English mercantile laws were enforced with great intrusiveness, which in turn had grave consequences for England's relationship with the American colonies. ${ }^{102}$ For instance, although the main point of protest in Boston over the Tea Act was taxation without representation, the Boston Tea Party was an act against the British government and the East India Company, which had a monopoly over tea importations to the colonies. The havoc wreaked by the English monopoly system on England's relationship with the American colonies cannot be overstated:

[T] he efforts of the English government, backed by English merchants and manufacturers, to deny to the Americans the right to compete in foreign markets and to secure the benefits of foreign competition was one of the most potent causes of the American Revolution. The spirit of monopoly which had permeated English business life for centuries and worked injury in so many ways now wrought irreparable harm to the British Empire by bringing about the loss of invaluable dominions and the irrevocable division of the English people. ${ }^{103}$

Thus, the English experience with monopolies influenced colonial America in two ways.

First, some colonies adopted their own versions of the Statute of Monopolies since the English

Statute of Monopolies and common law were generally thought not to extend to the colonies.

Second, England's monopolistic trade laws led to protest by the colonists and eventually the

${ }^{101}$ Thomas G. Barnes, Introduction to Coke on Littleton, reprinted in LAW, LIBERTY, AND PARLIAMENT: SELECTED EsSAYS ON THE WRITINGS OF SIR EDWARD CoKE 26 (Allen D. Boyer, ed., Liberty Fund, 2004) (quoting H.T. COLBOURN, THE LAMP OF EXPERIENCE 65 (1926)).

${ }^{102}$ Franklin D. Jones, Historical Development of the Law of Business Competition, 36 YALE L.J. 42, 49 (1926).

${ }^{103}$ Id. at 52. 
American Revolution, just as James I's monopolies had so outraged Englishmen in Parliament in the 1620's and led to the English Civil War in the 1640's. In both instances, complaints were made about taxation without representation and in both instances monopolies were in part to blame. King George III, like James I, imposed a double burden on his people by both taxing his people directly and by indirectly taxing them through the issuance of royal monopolies. The colonists were both taxed on imports, and they were made subject to British control over foreign trade without representation in Parliament.

\section{MONOPOLIES IN THE UNITED STATES}

\section{A. At the Founding}

The evils of the English monopolies and their impact on the American colonists guaranteed that that the right to be free from monopolies would draw attention in the drafting and ratifying of the federal constitution. Several of the Founders themselves, as well as the Antifederalists, and the state ratifying conventions took the position that the U.S. Constitution should have an anti-monopoly clause.

George Mason and Thomas Jefferson led the way in urging that the new U.S. Constitution contain an anti-monopoly clause. George Mason's concern about the evils of monopoly coupled with the grants of power to Congress in the Commerce Clause and the Necessary and Proper Clause led him, in part, to refuse to sign the proposed Constitution after the Philadelphia Convention. ${ }^{104}$ Mason was concerned that the Commerce Clause and the Necessary and Proper Clause might be used to regulate navigation in favor of the northern and eastern states by granting monopolies in trade:

\footnotetext{
104 Tyler T. Ochoa \& Mark Rose, The Antimonopoly Origins of the Patent And Copyright Clause, 84 J. PAT. \& TRADEMARK OFF. SOC'y, 909, 927 (2002) (citing 8 THE DOCUMENTARY HISTORY OF THE RATIFICATION OF THE CONSTITUTION 45 ((Merrill Jensen, ed. 1976)). Elbridge Gerry in Massachusetts refused to sign the proposed Constitution for similar reasons. Id. at 14.
} 
By requiring only a Majority to make all commercial and navigation Laws, the five Southern States (whose Produce and Circumstances are totally different from that of the eight Northern and Eastern States) will be ruined; [it] will enable the Merchants of the Northern and Eastern States not only to demand an exorbitant Freight, but to monopolize the Purchase of the Commodities at their own Price, for many years: to the . . . Impoverishment of the People: and the Danger is the greater, as the Gain on one Side will be in Proportion to the Loss on the other. . . . Under their own Construction of the general Clause . . . the Congress may grant Monopolies in Trade and Commerce. . . . ${ }^{105}$

George Mason’s concern was not exactly far-fetched given that the English colonial government had misused its powers over trade in precisely this way. Indeed, the English abuse of power is similar to the federal government's abuses of power in the nineteenth century; after 1861, the newly ascendant Northern Republican party protected Northern manufacturing interests to the disadvantage of the South with a policy of extremely high protectionist tariffs.

Thomas Jefferson also hated monopolies and thought that they should be constitutionally banned. In a letter to James Madison, complaining about the lack of a Bill of Rights in the proposed Constitution, Jefferson put the principle of freedom from government monopolies on a par with the protection of all of the other rights now enshrined in the Bill of Rights such as the freedom of speech and of religion:

I will now add what I do not like. First the omission of a bill of rights providing clearly and without the aid of sophisms for freedom of religion, freedom of the press, protection against standing armies, restriction against monopolies, the eternal and unremitting force of the habeas corpus laws, and trials by jury . . . Let me add that a bill of rights is what the people are entitled to against every government on earth, general or particular, and what no just government should refuse, or rest on inference. ${ }^{106}$

Specifically on the issue of monopolies, Jefferson also wrote:

[It] is better to . . . abolish . . . Monopolies, in all cases, than not to do it in any. . . . [S]aying there shall be no monopolies lessens the incitements to ingenuity . . . but the

105 Thomas B. Nachbar, Intellectual Property and Constitutional Norms, 104 CoLUM. L. REV. 272, 339 (2004) (quoting George Mason, Objections to the Constitution of Government Formed by the Convention (1787), reprinted in 2 The Complete ANTI-Federalist 11, 12-13 (Herbert J. Storing ed., 1981)).

${ }^{106}$ Id. at 799-800 (quoting Letter from Thomas Jefferson to James Madison (Dec. 20, 1787), reprinted in 12 THE PAPERS OF THOMAS JEFFERSON 438, 440 (J. Boyd ed. 1955) (emphasis added)). 
benefit even of limited monopolies is too doubtful to be opposed to that of their general suppression. ${ }^{107}$

In response, Madison argued that monopolies should be allowed in the limited circumstances where they were beneficial and that it was thus necessary not to have an outright prohibition against them:

With regard to Monopolies, they are justly classed among the greatest nuisances in Government. But it is clear that as encouragements to literary works and ingenious discoveries, they are not too valuable to be wholly renounced? Would it not suffice to reserve in all cases a right to the public to abolish the privilege at a price to be specified in the grant of it? ${ }^{108}$

In fact, Madison proposed during the Philadelphia convention to give the federal government the power to grant "charters of incorporation.”109 However, this proposal was voted down because, as Rufus King of Massachusetts argued, it might lead to “mercantile monopolies," as had happened in England before the American Revolution. ${ }^{110}$ George Mason also objected to giving Congress the power to grant charters of incorporation arguing that this power would lead to “monopolies of every sort.",111

Jefferson refused to give in, after reviewing a draft of the Bill of Rights, and he wrote to Madison again saying that he would have liked to have seen the following provision added to the Bill of Rights:

${ }^{107}$ Id. at 340 (quoting Letter from Thomas Jefferson to James Madison (July 31, 1788), in 13 THE PAPERS OF THOMAS JEFFERSON 442-43 (Julian P. Boyd ed., 1955)).

${ }^{108} 1$ BERNARD SCHWARTZ, THE BILL OF RighTS: A DOCUMENTARY HiSTORY 614-18 (1971) (quoting Letter from James Madison to Thomas Jefferson (Oct. 17, 1788)).

${ }^{109}$ Daniel A. Crane, Lochnerian Antitrust, 1 NYU J. L. LIBERTY 496, 506 (2005) (citing DANIEL A. FARBER \& SuZANNA SHERry, A History OF THE AMERICAN CONSTITUTION 141 (1990)).

${ }^{110}$ Id.; see also JAMEs MADisOn, NOTES OF THE DEBATES IN THE FEDERAL CONVENTION OF 1787638 (1985).

${ }^{111}$ Daniel A. Crane, Lochnerian Antitrust, 1 NYU J. L. LiBERTY 496, 506 (2005) (citing DANIEL A. FARBER \& SuZANNA SHERry, A History OF THE AMERICAN CONSTITUTION 141 (1990)); see also JAMEs MADISON, NOTES OF THE DEBATES IN THE FEDERAL CONVENTION OF 1787638 (1985). 
“Art. 9. Monopolies may be allowed to persons for their own productions in literature and their own inventions in the arts for a term not exceeding _ years but for no longer term and for no other purpose."112

Jefferson did not say what he meant by the word "monopoly," but the definition in Samuel Johnson’s dictionary at the time was: "the exclusive privilege of selling anything." 113

Interestingly, Jefferson also opposed the creation of the federal Post Office - perhaps the most venerable monopoly in American history. Jefferson wrote to James Madison that he thought the newly created Post Office was “a source of boundless patronage to the executive” and would:

job[] to members of Congress and their friends and a bottomless abyss of public money. You will begin by only appropriating the surplus of the post-office revenues; but other revenues will soon be called in to their aid and it will be a source of eternal scramble among the members, who can get the most money wasted in their states; and they will always get most who are meanest. ${ }^{114}$

As will be discussed in more depth below, Jefferson's opposition to the postal monopoly was shared by Lysander Spooner, the radical political reformer and abolitionist who was also an opponent of the postal monopoly and who challenged the federal postal monopoly in the midnineteenth century by creating a direct competitor, the American Letter Mail Company. ${ }^{115}$

Jefferson was not the only Framer to express concern about the Constitution and grants of monopoly privilege. The Antifederalists also spoke out about the evils and dangers of monopoly. ${ }^{116}$ The most outspoken of the Antifederalists on this topic was Agrippa. Looking to Europe's experience with monopolies in trade, Agrippa recognized that the main threat to

1121 BERNARD SCHWARTZ, THE BILL OF Rights: A DOCUMENTARY HistoRy 614-18 (1971) (quoting Letter from James Madison to Thomas Jefferson (Oct. 17, 1788)) (quoting Letter from Thomas Jefferson to James Madison (Aug. 28, 1789), in 15 THE PAPERS OF THOMAS JEFFERSON 367-68 (Julian P. Boyd ed., 1955)).

${ }^{113}$ SAMUEL JOHNSON, A DictionaRY OF THE ENGLiSh LANGUAGE (6th ed. 1785).

${ }^{114}$ Letter from Thomas Jefferson to James Madison (Mar. 6, 1796), available at http://presspubs.uchicago.edu/founders/documents/a1_8_7s4.html.

${ }^{115}$ See infra Part II.C.

${ }^{116} I d$. 
competition in most countries did not come from the market, but rather from the government itself:

In most countries of Europe, trade has been confined by exclusive charters. Exclusive companies are, in trade, pretty much like an aristocracy in government, and produce nearly as bad effects. ... . In the British islands all these circumstances together have not prevented them from being injured by the monopolies created there. Individuals have been enriched, but the country at large had been hurt . . . because they consequentially defeat the trade of the out-ports, and are also injurious to the general commerce, by enhancing prices and destroying that rivalship which is the great stimulus to industry. ${ }^{117}$

Other Antifederalists voiced the same concerns about monopolies. "A Son of Liberty" feared that " $[\mathrm{m}]$ onopolies in trade [will be] granted to the favorites of government, by which the spirit of adventure will be destroyed, and the citizens subjected to the extortion of those companies who will have an exclusive right to engross the different branches of commerce . . . ."118 The Federal Farmer wrote, “As monopolies in trade perhaps, can in no case be useful, it might not be amiss to provide expressly against them."119

Agrippa called for strong restraints on the ability of the federal government to grant monopolies in the new constitution, recognizing that the "unlimited power over trade, domestic as well as foreign, is another power that will more probably be applied to a bad than to a good purpose.” ${ }^{20}$ Echoing Adam Smith, whose book The Wealth of Nations was fittingly first published in 1776, Agrippa argued:

The freedom that every man, whether his capital is large or small, enjoys of entering into any branch that pleases him, rouses a spirit of industry and exertion, that is friendly to commerce. It prevents that stagnation of business which generally precedes public commotions. Nothing ought to be done to restrain this spirit. ${ }^{121}$

\footnotetext{
117 James P. Philbin, The Political Economy of the Antifederalists, 11 J. OF LIBERTARIAN STUDIES 79, 104 (1994) (citing Herbert J. STORING, 4 THE COMPLETE ANTI-FEDERALIST 104, 80, 81 (1981)).

${ }^{118} \mathrm{Id}$. at 105 (quoting Herbert J. Storing, 4 THE COMPLETE ANTI-FEDERALIST 492 (1981)).

${ }^{119}$ Id. (quoting LETTERS FROM THE FEDERAL FARMER TO THE REPUBLICAN 131 (Walter Hartwell Bennett, ed., 1978)).

${ }^{120}$ Id. (quoting Herbert J. StORING, 4 The COMPLETE ANTI-FEDERALIST 81 (1981)).

${ }^{121} \mathrm{Id}$.
} 
Six states wanted to include provisions banning monopolies and grants of special privilege in the federal constitution. Those states were New Hampshire, Massachusetts, New York, North Carolina, Virginia, and Rhode Island. ${ }^{122}$ Massachusetts’s proposal on February 6, 1788 was that the Constitution be amended to say "That Congress erect no company with exclusive advantages of commerce.”123 New Hampshire and North Carolina proposed similar amendments. ${ }^{124}$ New York recommended: “[t]hat the congress do not grant monopolies, or erect any company with exclusive advantages of commerce.”125 Rhode Island's belated ratification of the Constitution in 1790 recommended the same language as New York, although it was too late to have an influence. ${ }^{126}$ Virginia's proposal was "That no man or set of men are entitled to separate or exclusive public emoluments or privileges from the community, but in consideration of public services, which not being descendible, neither ought the offices of magistrate, legislator, or judge, or any other public office, to be hereditary.” ${ }^{27}$ All of these proposed antimonopoly amendments to the Constitution came from the state ratifying conventions, but since the task of writing the federal Bill of Rights in response to the requests for amendments from the states fell to newly elected Congressman James Madison, an anti-monopoly clause was omitted

\footnotetext{
122 Tyler T. Ochoa \& Mark Rose, The Antimonopoly Origins of the Patent And Copyright Clause, 84 J. PAT. \& TRADEMARK OFF. SOC'Y, 909, 927 (2002) (citing 2 THE DOCUMENTARY HISTORY OF THE CONSTITUTION OF THE United STATES OF AMERICA 1786-1870 95, 142, 198, 274 (State Dept. 1894)); Michael Conant, Antimonopoly Tradition Under the Ninth and Fourteenth Amendments: Slaughter-House Cases Re-Examined, 31 EMORY L.J. 785, 800 (1982); see also Donald S. Lutz, The States and the U.S. Bill of Rights, 16 S. ILL. U. L.J. 251, 256-60 (1992).

1232 ELLIOT'S DEBATES, Convention of Massachusetts, February 6, 1788, available at http://www.teachingamericanhistory.org/ratification/elliot/vol2/massachusetts0206.html\#amendments.

${ }^{124}$ Tyler T. Ochoa \& Mark Rose, The Antimonopoly Origins of the Patent And Copyright Clause, 84 J. PAT. \& TRADEMARK OFF. SOC’Y, 909, 927 (2002).

${ }^{125}$ Ratification of the Constitution by the State of New York, in DOCUMENTS ILLUSTRATIVE OF THE FORMATION OF THE UNION OF THE AMERICAN STATES (Selected, Arranged, and Indexed by Charles C. Tansill), available at http://www.teachingamericanhistory.org/ratification/tansill/ratification-newyork.html; see also Tyler T. Ochoa \& Mark Rose, The Antimonopoly Origins of the Patent And Copyright Clause, 84 J. PAT. \& TRADEMARK OFF. SOC'Y, 909, 927 (2002).

${ }^{126}$ Michael Conant, Antimonopoly Tradition Under the Ninth and Fourteenth Amendments: Slaughter-House Cases Re-Examined, 31 EMORY L.J. 785, 800 (1982).

127 The Debates in the Convention of the Commonwealth of Virginia on the Adoption of the Federal Constitution In Convention, Richmond, Friday, June 27, 1788, available at http://www.teachingamericanhistory.org/ratification/elliot/vol3/june27.html.
} 
from the federal Bill of Rights. Madison was stubborn, persistent, and successful in keeping an anti-monopoly clause out of the Founders Constitution!

This is remarkable since even Alexander Hamilton, a notorious proponent of a strong central government and of mercantilism, acknowledged the pressure from the states for an antimonopoly clause. As Hamilton said in regards to the constitutionality of a national bank:

It is remarkable that the State conventions, who had proposed amendments in relation to this point, have most, if not all of them, expressed themselves nearly thus: Congress shall not grant monopolies, nor erect any company with exclusive advantages of commerce! Thus, at the same time, expressing their sense, that the power to erect trading companies or corporations was inherent in Congress, and objecting to it no further than as to the grant of exclusive privileges. ${ }^{128}$

Interestingly, only one of the states that sought a federal anti-monopoly clause (North Carolina) actually banned monopolies itself in its own state constitution. ${ }^{129}$ This suggests that there was greater concern about monopoly abuses at the federal level than at the state level. This makes some sense when we remember that colonial America found itself confronted with English monopolies when it had previously had a powerful central government. It must also be noted that, in drafting their own state constitutions, the states focused more on the structures of state government than they did on producing state bills of rights. Only seven states had separate state bills of rights at the Founding while four others included some protection of rights within their constitutions. ${ }^{130}$

Of course, no ban on monopolies made its way into the federal constitution or Bill of Rights. This is probably in large part due to Madison's view that representational government at the federal level would prevent a repeat of the English experience with monopolies:

\footnotetext{
${ }^{128}$ Robert G. Natelson, The Founders' Hermeneutic: The Real Original Understanding of Original Intent, 68 Оніо Sт. L.J. 1239, n. 381 (quoting Opinion of Alexander Hamilton on the Constitutionality of a National Bank, 1791, available at The Avalon Project at Yale Law School, http:// www.yale.edu/lawweb/avalon/amerdoc/bankah.htm)).

${ }^{129}$ See infra Part III.

${ }^{130}$ Michael Conant, Antimonopoly Tradition Under the Ninth and Fourteenth Amendments: Slaughter-House Cases Re-Examined, 31 EMORY L.J. 785, 799 (1982).
} 
Is there not also infinity less danger in this abuse in our Governments than in most others? Monopolies are sacrifices of the many to the few. Where the power is in the few it is natural for them to sacrifice the many to their own partialities and corruptions. Where the power as with us is in the many not in the few the danger cannot be very great that the few will be thus favored. It is much more to be dreaded that the few will be unnecessarily sacrificed to the many. ${ }^{131}$

Madison made it clear elsewhere that the right to be free of monopolies was of vital importance.

Madison expressed his recognition of the importance of the right of individuals to earn a living in

their trade when he proclaimed:

That is not a just government, nor is property secure under it, where arbitrary restrictions, exemptions, and monopolies deny to part of its citizens that free use of their faculties, and free choice of their occupations, which not only constitute their property in the general sense of the word; but are the means of acquiring property strictly so called. ${ }^{132}$

\section{B. Monopolies and the Original Federal Constitution}

There are two provisions in the federal constitution which relate closely to the English history with monopolies. First, the Patent and Copyright Clause in Article 1, Section 8 provides that "Congress shall have the Power ... To promote the Progress of Science and useful Arts, by securing for limited Times to Authors and Inventors the exclusive Right to their respective Writings and Discoveries.”133 As discussed above, Thomas Jefferson reluctantly agreed to the inclusion of this clause in his correspondence with James Madison. Just as the Statute of Monopolies in 1624 explicitly left some monopolies in place, ${ }^{134}$ so too did the Framers of the U.S. Constitution allow for monopolies in the form of copyrights and patents for new writings and inventions so as to promote industry and creativity.

\footnotetext{
131 BERNARD SCHWARTZ, THE BILl OF RightS: A DOCUMENTARY HiSTORY 614-18 (1971) (quoting Letter from James Madison to Thomas Jefferson (Oct. 17, 1788)).

132 James W. Ely, To Pursue Any Lawful Trade or Avocation: The Evolution of Unenumerated Economic Rights in the Nineteenth Century, 8 U. PA. J. CONST. L. 917, 931 (2006) (quoting JAMES MADISON, PrOPERTY (Mar. 29, 1792), reprinted in 1 ThE FoundeR's Constitution: MAJOR TheMEs 598, 598 (Phillip B. Kurland \& Ralph Lerner eds., 1987)).

${ }^{133}$ U.S. CONST. Art I, § 8.

${ }^{134}$ An Act concerning Monopolies and Dispensations with Penal Laws, and the Forfeitures thereof (Statute of Monopolies), 21 Jam., c. 3 (1624) §§ 5-6.
} 
The other provision in the original Constitution which was relevant to the monopoly issue was the Privileges and Immunities Clause of Article IV, Section 2, which states "The Citizens of each State shall be entitled to all Privileges and Immunities of Citizens in the several States.”135 Similar privileges and immunities clauses had also been included in many of the colonial charters and in the Articles of Confederation, which was in some respects America's first constitution. $^{136}$ It is clear from an early draft of the Articles of Confederation that the “privileges” and “immunities” which the Articles of Confederation protected were the traditional rights that the American people had always had as Englishmen. The Articles thus provided that: “The Inhabitants of each Colony shall henceforth always have the same Rights, Liberties, Privileges, Immunities and Advantages in the other Colonies, which the said Inhabitants now

\footnotetext{
${ }^{135}$ U.S. CONST. Art IV, § 2. The Privileges and Immunities Clause of Article IV and the Privileges or Immunities Clause of the Fourteenth Amendment have been the subject of much recent scholarly attention. Modern scholarship on the original meaning of the Privileges or Immunities Clause began with John Harrison's article Reconstructing the Privileges or Immunities Clause, 101 Yale L. J. 1385 (1992), which argued that the Clause was on an antidiscrimination guarantee and not a font of substantive due process individual rights. Phillip Hamburger reaches the same conclusion in Privileges or Immunities, 105 Nw. U. L. Rev. 61 (2011). Akhil Reed Amar and Randy Barnett read the Clause as protecting both against discrimination and as conferring unenumerated individual rights. Akhil Reed Amar, America's Unwritten Constitution: The Precedents and Principles We Live By 157 (forthcoming 2012); Randy Barnett, Restoring the Lost Constitution: The Presumption of Liberty 62-65 (2004). Kurt Lash argues in a series of three law review articles which he is turning into a book that the Privileges or Immunities Clause protects both against discrimination and that it also protects enumerated but not unenumerated individual rights. Kurt Lash, The Constitutional Referendum of 1866: Andrew Johnson and the Original Meaning of the Privileges or Immunities Clause, forthcoming law review article on file with the authors (2012); Kurt Lash, The Origins of the Privileges or Immunities Clause, Part I: "Privileges and Immunities" as an Antebellum Term of Art, 98 Geo. L. J. 1241 (2010); Kurt Lash, The Origins of the Privileges or Immunities Clause, Part II: John Bingham and the Second Draft of the Fourteenth Amendment, 99 Geo. L. J. 329 (2011). Robert Natelson argues in The Original Meaning of the Privileges and Immunities Clause, 43 Georgia L. Rev. 1117 (2009) for the John Harrison and Phillip Hamburger interpretation of the Privileges and Immunities Clause of Article IV, Section 2. Our own view of the Privileges or Immunities Clause of the Fourteenth Amendment is that it protects: 1) against laws that discriminate on the basis of class or caste and that are not just laws enacted for the good of the whole people; and that 2) it protects both enumerated individual rights and unenumerated individual rights that are deeply rooted in history and tradition subject always to the caveat that the states can override such rights if they pass a just law that is enacted for the general good of the whole people. Our reading grows out of the foundational case of Corfield $v$. Coryell, 6 Fed. Cas. 546 no. 3230 C.C.E.D. Pa. (1823).
}

${ }^{136}$ The Articles of Confederation provided in Article VI: "The better to secure and perpetuate mutual friendship and intercourse among the people of the different States in this union, the free inhabitants of each of these States, paupers, vagabonds, and fugitives from justice excepted, shall be entitled to all privileges and immunities of free citizens in the several States.” 
have ...."137 Of course, those traditional rights of Englishmen included the right to be free from monopolies, so that right was conferred on Americans by the Articles of Confederation as well, and it informs the original meaning of the Privileges and Immunities Clause of Article IV.

This meaning of the Privileges and Immunities clause in Article IV as banning monopolies was recognized in the years following the adoption of the federal constitution. While riding circuit in 1823, Justice Washington explained the meaning of the Privileges and Immunities Clause of Article IV in Corfield v. Coryell. Corfield is a case that involved a challenge to a New Jersey law which forbade non-residents from gathering oysters and clams.

Although Justice Washington upheld the state law that was challenged, he explained that the Privileges and Immunities Clause protected a large number of fundamental rights:

We feel no hesitation in confining these expressions to those privileges and immunities which are, in their nature, fundamental; which belong, of right, to the citizens of all free governments; and which have, at all times, been enjoyed by the citizens of the several states which compose this Union, from the time of their becoming free, independent, and sovereign. What these fundamental principles are, it would perhaps be more tedious than difficult to enumerate. They may, however, be all comprehended under the following general heads: Protection by the government; the enjoyment of life and liberty, with the right to acquire and possess property of every kind, and to pursue and obtain happiness and safety; subject nevertheless to such restraints as the government may justly prescribe for the general good of the whole.

The right of a citizen of one state to pass through, or to reside in any other state, for purposes of trade, agriculture, professional pursuits, or otherwise; to claim the benefit of the writ of habeas corpus; to institute and maintain actions of any kind in the courts of the state; to take, hold and dispose of property, either real or personal; and an exemption from higher taxes or impositions than are paid by the other citizens of the state; may be mentioned as some of the particular privileges and immunities of citizens, which are clearly embraced by the general description of privileges deemed to be fundamental: to which may be added, the elective franchise, as regulated and established by the laws or constitution of the state in which it is to be exercised. These, and many others which might be mentioned, are, strictly speaking, privileges and immunities, and the enjoyment of them by

${ }^{137}$ Michael Conant, Antimonopoly Tradition Under the Ninth and Fourteenth Amendments: Slaughter-House Cases Re-Examined, 31 EMORY L.J. 785, 813 (1982) (quoting 5 JOURNALS OF THE CONTINENTAL CONGRESS 547 (1906)). 
the citizens of each state, in every other state, was manifestly calculated (to use the expressions of the preamble of the corresponding provision in the old articles of confederation) 'the better to secure and perpetuate mutual friendship and intercourse among the people of the different states of the Union. ${ }^{138}$

Justice Washington's dictum seems to recognize federal constitutional protection for broad economic rights including the right to choose a trade or profession. As we will discuss shortly, Justice Washington's definition of privileges and immunities was relied on heavily by the drafters of the Privileges or Immunities Clause of the Fourteenth Amendment, and later by the justices of the U.S. Supreme Court in their landmark decision in the Slaughter-House Cases which interpreted the Fourteenth Amendment’s Privileges or Immunities Clause.

The anti-monopoly principle was also evident early in our federal constitutional history in the Supreme Court's Contracts Clause caselaw. Nineteenth Century Contracts Clause cases like Dartmouth College v. Woodward in 1819, and Charles River Bridge v. Warren Bridge in 1837, both reflect concerns about monopoly. In Dartmouth College v. Woodward, decided in 1819, the Marshall Court held that Dartmouth College’s corporate charter, which was first granted by King George III in 1769, was a private contract between two parties which was protected by the Contracts Clause in Article I, Section 10. ${ }^{139}$ Thus, although the state argued that the charter was in fact a license to do business that the state could subsequently alter, the Supreme Court held that the New Hampshire legislature could not alter the corporation's charter by changing the identity of the corporation's trustees because doing so impaired a private contract among private individuals. The Dartmouth College case was thus crucial in the empowering of private corporations because once corporations were created, the state could not subsequently take away

\footnotetext{
${ }^{138} 6$ Fed. Cas. 546, no. 3230 (C.C.E.D.Pa. 1823).

13917 U.S. (4 Wheat.) 518 (1819).
} 
their corporate charter rights. ${ }^{140}$ The reasoning of the Court's opinion applied to for profit corporations, as well as to non-profit corporations like Dartmouth College, and made it clear that while the English government could revoke corporate "monopoly" powers, the State governments in the United States could not do so without running afoul of the Contracts Clause. This holding greatly empowered U.S. corporations and contributed substantially to U.S. economic growth in the Nineteenth Century. Once corporations were no longer considered to be always the monopoly recipients of special governmental grants of privilege, U.S. economic growth really took off.

In 1837 the Taney Court modified and limited the Dartmouth College decision in Charles River Bridge v. Warren Bridge. ${ }^{141}$ In this case, Massachusetts had contracted in 1785 with the Charles River Bridge Company to build and maintain a toll bridge across the Charles River and in 1792 the state legislature extended the charter grant to the Charles River Bridge Company from forty to seventy years. The population in Boston grew extremely rapidly, and so in 1828 the state legislature changed its mind about the seventy year charter, and it allowed another company to build a competing bridge nearby, the Warren Bridge, which would initially charge a fee but which would eventually become free for travelers to use. Once the Warren Bridge became free to use, the value of the Charles River Bridge was destroyed. The Charles River Bridge Company, relying on Dartmouth College, sued arguing that its corporate charter monopoly was protected by the Contracts Clause. The argument was that the state of Massachusetts could not breach its contract with the Charles River Bridge Company to have

\footnotetext{
140 JAMES WiLlARD HuRST, THE LEGITIMACY OF THE BuSINESS CORPORATION 1790-1970, at 16 ("What the corporate charter gave and what the Constitution protected was thus not only an official license but also a pattern for organizing certain human relations.”)

14136 U.S. 420 (1837).
} 
exclusive rights to operate a toll bridge over the Charles River by allowing another company to manage a competing free bridge.

Chief Justice Roger B. Taney, a Jacksonian, held that in cases where a corporation has an agreement with the government for exclusive monopoly-like privileges, the terms of the agreement should be construed as narrowly as possible because monopolies were disfavored both as matter of constitutional history and public policy. Chief Justice Taney held that the charter merely granted the Charles River Bridge Company the right to build a bridge, but not necessarily the exclusive privilege of maintaining the only bridge across the river. This would undoubtedly have surprised the original builders of the Charles River Bridge had they known as much back in 1785 when the bridge was built. A central concern for Chief Justice Taney was that upholding the charter as a grant of exclusive privilege would promote monopoly, which he viewed as contrary to English law and to American law by adoption:

Borrowing, as we have done, our system of jurisprudence from the English law; and having adopted, in every other case, civil and criminal, its rules for the construction of statutes; is there anything in our local situation, or in the nature of our political institutions, which should lead us to depart from the principle, where corporations are concerned? . . . We think not; and it would present a singular spectacle, if, while the courts in England are restraining, within the strictest limits, the spirit of monopoly, and exclusive privileges in nature of monopolies, and confining corporations to the privileges plainly given to them in their charter; the courts of this country should be found enlarging these privileges by implication; and construing a statute more unfavorably to the public, and to the rights of community, than would be done in a like case in an English court of justice. ${ }^{142}$

Chief Justice Taney explained that if the charter given to the Charles River Bridge company were construed broadly, as granting an exclusive privilege to operate a bridge for seventy years, it would become difficult for courts to draw a line as to how far that right should extend. For example, charters for turnpike roads were by 1837 facing competition from charters issued to newly created railroads. If turnpike charters were interpreted broadly by the courts, then the

\footnotetext{
${ }^{142} I d$. at $545-46$.
} 
holders of turnpike charters might use their old charters to prevent technological change by challenging the railroad charters that were allowing for competition. ${ }^{143}$ As Stanley Kutler explains in his book on the Charles River Bridge case, the Charles River Bridge Company's owners were attacked for being "interests [that were] entrenched and prospering through special privileges” obtained by legal means. ${ }^{144}$ Jacksonians, like Chief Justice Taney, were ardently opposed to government grants of monopoly and special privileges to the powerful and wealthya phenomenon that Americans today call "Crony Capitalism.",145

Justice Joseph Story, the closest ally of the by then deceased Chief Justice John Marshall, and who had concurred in the decision in the Dartmouth College case, wrote a scathing dissent, in Charles River Bridge. He argued that the Charles River Bridge's exclusive privilege should be protected by the Contracts Clause. Despite his association with the Democratic-Republican Party, Justice Story was greatly influenced by Alexander Hamilton and Chief Justice John Marshall, and he thus believed that private property rights should be strongly protected and that commerce should be promoted. He saw the Charles River Bridge case not as a defeat for Crony Capitalism but as a violation of private property rights. Justice Story was opposed to Jacksonian democracy because he feared that popular majorities would invade the private property rights of the wealthy and would hurt private businesses. The tension between Taney's and Story's views - the protection of corporate property rights granted by the state versus an aversion to special laws and monopoly privileges—helped to shape the debate over the Fourteenth Amendment in the three decades after the Charles River Bridge case was decided.

\footnotetext{
${ }^{143}$ Id. at 551-52; see also THOMAS MERRILL \& HENRY SMITH, OXFORD INTRODUCTIONS TO U.S. LAW: PROPERTY 225 (2010).

${ }^{144}$ Stanley I. Kutler, Privilege and Creative Destruction: The Charles River Bridge Case 157 (1978).

${ }^{145} \mathrm{Id}$.
} 
Importantly, the Charles River Bridge case had an "immediate and widespread impact at the state level." 146 As Stanley Kutler notes in his book about the case, it "opened the floodgates and courts now directly confronted and denied exaggerated implied claims of vested rights. The state court reports are replete with cases implementing the Charles River Bridge doctrine.»147 For example, in The Mohawk Bridge Co. v. Utica and Schenectady Railroad Co., a New York court applied Charles River Bridge's rule of strict construction to hold that a bridge proprietor's charter did not prohibit competition from a ferry. ${ }^{148}$ Similarly, in Tuckahoe Canal Co. v. Tuckahoe and James River Railroad Co., the Virginia Court of Appeals held that a canal company's charter did not give the canal company an exclusive right of way, and that a railroad company could construct bridges that would compete with the canal. ${ }^{149}$ Fearing the tendency of holders of special privileges to claim more rights than had originally been intended, the court said that "monopoly is very ingenious in extending its rights and enlarging its pretensions." 150

\section{The Fourteenth Amendment: A Ban on Class-Based Legislation}

Chief Justice Taney's concern with the creation of monopolies in the Charles River Bridge case was part of a movement beginning in the early nineteenth century to ban special or partial laws. During this period, many states amended their constitutions to prohibit the state from granting special privileges or monopolies. Prominent legal commentators, such as Chancellor Kent and later Thomas Cooley, argued that laws must be general and not class-based. There was widespread opposition to class legislation, the granting of exclusive privileges, and to government conferred monopolies. This Jacksonian concern, which was eventually adopted by

\footnotetext{
${ }^{146}$ Stanley Kutler, Privilege AND Creative Destruction 135 (1971)

${ }^{147} I d$. at 137.

${ }^{148} \mathrm{Id}$.

${ }^{149} \mathrm{Id}$.

${ }^{150} \mathrm{Id}$.
} 
Abolitionists and Republicans, helped to lead to the adoption of the second sentence of Section One of the Fourteenth Amendment in 1868, which provides:

No State shall make or enforce any law which shall abridge the privileges or immunities of citizens of the United States; nor shall any State deprive any person of life, liberty, or property, without due process of law; nor deny to any person within its jurisdiction the equal protection of the laws.

We think the Fourteenth Amendment has its roots in part in the Jacksonian fear of monopolies and grants of special privilege and that the Amendment bans not only systems of caste but also all special or partial laws that single out certain persons or classes for special benefits or burdens. ${ }^{151}$ This is essentially the view that was taken by the four dissenters in The SlaughterHouse Cases.

If there was one thing that all Jacksonians hated, it was government conferred monopolies or special privileges or class legislation. "Class" in this sense refers to "class legislation"-any legislation which singles out groups or individuals or classes of people and grants them special privileges or imposes on them special burdens and which privileges or burdens are not shared by the rest of society. ${ }^{152}$ The Jacksonian aversion to class legislation is broader than an aversion to "caste," a term which refers only to hereditary class traits which may be immutable (such as race, gender, or other physical features) or which are theoretically mutable like gender, although they are practically immutable because of social attitudes. A wellknown example of theoretically mutable but practically immutable characteristics is the traditional Hindu caste system of the Nineteenth Century wherein a hereditary social order was

\footnotetext{
${ }^{151}$ For an excellent explanation of why this is the case, see also Melissa L. Saunders, Equal Protection, Class Legislation, and Colorblindness, 96 MiCH. L. REV. 245 (2003).

${ }^{152}$ Melissa L. Saunders, Equal Protection, Class Legislation, and Colorblindness, 96 MiCH. L. REV. 245, 248 (2003).
} 
created that distinguished Brahmins from Untouchables with several other castes in between. ${ }^{153}$ Notably, a nineteenth century dictionary definition of caste described it as not only being based on physical or racial features but as also including a "tribe or class in the same profession" or people with "fixed occupations" or "with "the same rank, profession, or occupation." 154 The view that class or caste legislation was reprehensible came to be widely held in the 1860s by the Framers of the Fourteenth Amendment. ${ }^{155}$

Importantly, opposition to class legislation was not a new idea invented by the Jacksonians, but it was instead an idea that was deeply rooted in John Locke's belief that the role of government is to protect individuals’ natural rights. ${ }^{156}$ Locke believed that laws should have equal application to everyone in society and that the government should not use its power to create laws that favored or burdened particular groups. ${ }^{157}$ The opposition to special interest laws, however, was not due solely to Lockean philosophical ideas on the proper role of government. There were also important practical reasons to oppose class legislation because favoritism or discrimination undermines the democratic process and encourages corruption. ${ }^{158}$ The Framers of the original Constitution sometimes expressed this view, as James Madison did, when he said that the state should be "neutral between different parts of society," and that “equality ought to be the basis of every law.”159

153 See Steven G. Calabresi \& Julia T. Rickert, Originalism and Sex Discrimination, 90 TEX. L. REV. 1, 17 n. 72 (2011) (citing nineteenth century dictionaries); see also id. at 17 (quoting Senator Charles Sumner referencing the Indian Caste system and stating that a caste system is when one person "claim[s] hereditary rank and privilege" and another is “doomed to hereditary degradation and disability”).

${ }^{154}$ Steven G. Calabresi \& Abe Salander, supra Note _, at _ _ (citing ChAUNCEY A. GOODRICH, A PRONOUNCING AND Defining Dictionary Of THE English LANGUAGE 64, 75 (1856); Noah Webster, An American Dictionary of the English Language 152 (1857); JOSEPH E. WORCESTER, A UNIVERSAL AND CRITICAL DiCTIONARY OF THE ENGLISH LANGUAGE 107-08, 128 (1849)).

155 See infra Part II.B.

${ }^{156}$ Melissa L. Saunders, Equal Protection, Class Legislation, and Colorblindness, 96 MiCH. L. REV. 245, 24748 (2003).

${ }^{157}$ Id. at 253.

${ }^{158} \mathrm{Id}$. at 254-55.

${ }^{159} \mathrm{Id}$. at 256. 
There is ample support in the text of the original federal constitution for the idea that there should be generality in lawmaking and equality before the law. As Steven Calabresi and Abe Salander point out, there are many instances where the original constitution requires that the laws be general and not class-based. ${ }^{160}$ First, the preamble to the Constitution states that the purpose of the Constitution is to "provide for the common defence" and "promote the general Welfare.” ${ }^{161}$ Likewise, Article I, Section 8 empowers Congress “[t]o establish an uniform Rule of Naturalization, and uniform Laws on the subject of Bankruptcies throughout the United States.”162 The Full Faith and Credit Clause allows Congress to pass only "general laws."163 The Constitution's ban on bills of attainder, ex post facto laws, and titles of nobility may also be viewed as bans on various forms of class legislation.

President Andrew Jackson's famous hatred for the Bank of the United States stemmed in part from the fact that the Bank was a private institution which enjoyed special privileges above and beyond those enjoyed by ordinary banks. In his message to Congress in 1832 vetoing a statute that would have renewed the corporate charter of the Bank of the United States, a veto message which Roger B. Taney helped to draft, President Jackson repeatedly referred to the bank as a monopoly because it was the only bank allowed to operate under a charter from the federal government and because it had significant control over the foreign and domestic exchange. Pointing to the Patent and Copyrights Clause, which gives Congress the power to grant monopolies in the limited instances of patent and copyright, President Jackson wrote that any other grant of monopoly was the equivalent of a legislative amendment to the Constitution:

\footnotetext{
${ }^{160}$ Steven G. Calabresi \& Abe Salander,supra Note __ (on file with authors).

${ }^{161}$ U.S. CONST. Preamble (emphasis added).

${ }^{162}$ U.S. CONST. Art. I, § 8, cl. 4 (emphasis added).

${ }^{163}$ U.S. CONST. art. IV, § 1 ("Full Faith and Credit shall be given in each State to the public Acts, Records, and judicial Proceedings of every other State. And the Congress may by general Laws prescribe the Manner in which such Acts, Records and Proceedings shall be proved, and the Effect thereof.”)
} 
Every act of Congress, therefore, which attempts by grants of monopolies or sale of exclusive privileges for a limited time, or a time without limit, to restrict or extinguish its own discretion in the choice of means to execute its delegated powers is equivalent to a legislative amendment of the Constitution, and palpably unconstitutional. ${ }^{164}$

For Jackson, the Bank of the United States, as a monopoly, was contrary to the principle of the equal protection of the laws:

Many of our rich men have not been content with equal protection and equal benefits, but have besought us to make them richer by act of Congress. By attempting to gratify their desires we have in the results of our legislation arrayed ... interest against interest, and man against man, in a fearful commotion which threatens to shake the foundations of our Union. . . . If we can not at once, in justice to interests vested under improvident legislation, make our Government what it ought to be, we can at least take a stand against all new grants of monopolies and exclusive privileges, against any prostitution of our Government to the advancement of the few at the expense of the many .... ${ }^{165}$

Rather than accede to the rich men's request, the government should "confine itself to equal protection, and, as Heaven does its rains, shower its favors alike on the high and the low, the rich and the poor." 166 People should "take a stand against all new grants of monopolies and special privileges, against the prostitution of our Government to the advancement of the few at the expense of the many.”167 Jackson's hatred of banks was not unique to him, however. There were similar challenges brought to the special privileges granted to banks in some state courts during the nineteenth century as well. For example, in 1813, the special debt recovery rules for a state bank in North Carolina were challenged as a violation of North Carolina's constitution, which provided that "no man, or set of men, are entitled to any exclusive or separate emoluments or privileges from the community, but in consideration of public services." ${ }^{\text {"68 }}$ Similarly, in 1856

\footnotetext{
${ }^{164}$ President Jackson’s Veto Message Regarding the Bank of the United States (July 10, 1832), available at http://avalon.law.yale.edu/19th_century/ajveto01.asp.

${ }^{165} \mathrm{Id}$.

${ }^{166} \mathrm{Id}$

${ }^{167}$ Id.

${ }^{168}$ Bank of Newburn v. Taylor, 2 Mur. 266 (N.C. 1813) (the court found the bank’s debt recovery rules constitutional, since the bank was given this privilege because of "the consideration for it is the public good.”).
} 
a state bank charter in Indiana was challenged under that state's privileges or immunities clause because it was exempt from certain forms of taxation. ${ }^{169}$

The antimonopoly cause also influenced opposition to the federal government's postal monopoly. In 1844, Lysander Spooner, the famous political reformer and abolitionist, founded the American Letter Mail Company in order to challenge the constitutionality of the Post Office. Spooner opposed the federal postal monopoly. ${ }^{170}$ Spooner argued that the federal postal monopoly exceeded the grant of power given too Congress in Article I, Section 8, Clause 7 "To establish Post Offices and post Roads,” and Spooner alleged that the Post Office charged exorbitantly high postage rates due to its monopoly power. ${ }^{171}$ Spooner's constitutional argument, with which Justice Jospeh Story agreed, was that the "power to establish post offices and post roads" is narrower than the power given to Congress under the Articles of Confederation, which granted Congress the "sole and exclusive right [of] . . establishing and regulating post offices.”172 Like Sir Edward Coke, Spooner understood the creation of monopolies as a practice of arbitrary and despotic governments:

The idea, that the business of carrying letters is, in its nature, a unit, or monopoly, is derived from the practice of arbitrary governments, who have either made the business a monopoly in the hands of the government, or granted it as a monopoly to individuals. There is nothing in the nature of the business itself, any more than in the business of transporting passengers and merchandise, that should make it a monopoly, either in the hands of the government or of individuals. Probably one great, if not the principal motive of despotic governments, for maintaining this monopoly in their own hands, is, that in case of necessity, they may use it as an engine of police, and in times of civil commotion, it is used in this manner. The adoption of the same system in this country shows how blindly and thoughtlessly

\footnotetext{
${ }^{169}$ Wright v. Defrees, 8 Ind. 298 (1856).

${ }^{170}$ Kelly B. Olds, The Challenge to the U.S. Postal Monopoly, 15 CATO JouRnAL 1, 12 (1995), available at http://www.cato.org/pubs/journal/cj15n1/cj15n1-1.pdf.

${ }^{171}$ Lucille J. Goodyear, Spooner v. U.S. Postal System, AMERICAN LEGION MAG. (Jan. 1981), available at http://www.lysanderspooner.org/STAMP3.htm.

${ }^{172}$ Kelly B. Olds, The Challenge to the U.S. Postal Monopoly, 15 CATO JournaL 1, 12-13 (1995).
} 
we follow the precedents of other countries, without reference to the despotic purposes in which they had their origin. ${ }^{173}$

Spooner concluded that:

"the only absolute constitutional guaranty, that the people have against all these evils and dangers, is to be found in the principle, that they have the right, at pleasure, to establish mails of their own. And if the people should now surrender this principle, they would thereby prove that their minds are most happily adapted to the degradation of slavery. ${ }^{174}$

As discussed earlier, Thomas Jefferson-also opposed to monopolies-was wary of Congress's power to create postal roads and wrote to Madison that he thought this would "be a source of boundless patronage to the executive, jobbing to members of Congress and their friends, and a bottomless abyss of public money.”175 Jefferson's concerns, voiced nearly fifty years prior, thus resurfaced in Spooner's efforts to challenge the federal government's postal monopoly. However, due to a combination of fines, government seizure of the mail, and competition from other mail delivery provider’s Spooner's American Letter Mail Company was forced out of business. ${ }^{176}$ Nonetheless, Spooner is credited with significantly lowering the postage rates—his obituary describes him as the "father of cheap postage in America.”177

As Professor Melissa Saunders explains in an excellent law review article entitled "Equal Protection, Class Legislation, and Colorblindness,” at least two esteemed legal commentators and treatise writers prior to 1868, Chancellor Kent and Thomas Cooley, adopted and endorsed the Jacksonian idea that the laws must be general and that they may not be class- or caste-

\footnotetext{
${ }^{173}$ Lysander Spooner, The Unconstitutionality of the Laws of Congress, prohibiting Private Mails (1844), available at

http://oll.libertyfund.org/index.php?option=com_staticxt\&staticfile=show.php\%3Ftitle=2231\&layout=html.

${ }^{174} \mathrm{Id}$.

${ }^{175}$ Letter from Thomas Jefferson to James Madison (Mar. 6, 1796), available at http://presspubs.uchicago.edu/founders/documents/a1_8_7s4.html.

${ }^{176}$ Kelly B. Olds, The Challenge to the U.S. Postal Monopoly, 15 CATO Journal 1, 13 (1995).

${ }^{177}$ N.Y. TIMES, The Father of Cheap Postage, available at http://query.nytimes.com/mem/archivefree/pdf?res=F20716FC3C5413738DDDAC0994DD405B8784F0D3.
} 
based. ${ }^{178}$ For example, Chancellor Kent wrote in 1816 that "laws should 'have a general and equal application' and be 'impartial in the imposition which [they] create.”"179 Thomas Cooley similarly wrote about "unequal and partial legislation” that was invalidated in various state court cases. ${ }^{180}$ Cooley considered it axiomatic in state constitutional law that

[T]hose who make the laws are to govern by promulgated, established laws, not to be varied in particular cases, but to have one rule for rich and poor . . . [E]very one has a right to demand that he be governed by general rules, and a special statute which . . . singles his case out as one to be regulated by a different law from that which is applied in all similar cases, would not be legitimate legislation. ${ }^{181}$

Cooley also wrote that "Equality of rights, privileges, and capacities unquestionably should be the aim of the law" and that "Special privileges are always obnoxious, and discriminations against persons or classes are still more so.”182 This view found its way into several state constitutions, as will be discussed in more detail in the section below. A number of states had adopted constitutional provisions aimed at prohibiting special or partial laws prior to the ratification of the Fourteenth Amendment in 1868.

There was an important exception to the ban on class legislation, however. If the law could be shown to serve a "public purpose," it would be upheld. As Justice Field later explained in the 1885 case, Barbier v. Connolly, the Fourteenth Amendment prohibits “[c]lass legislation, discriminating against some and favoring others," but does not prohibit "legislation which, in carrying out a public purpose, is limited in its application” to certain individuals or groups. ${ }^{183}$

\footnotetext{
${ }_{178}$ Melissa L. Saunders, Equal Protection, Class Legislation, and Colorblindness, 96 MiCH. L. REV. 245 (2003).

${ }^{179} \mathrm{Id}$. at 259 (quoting WILLIAM KENT, MEMOIRS AND LETTERS OF JAMES KENT, LL.D 163 (1898) (quoting from an opinion that Kent authored in 1816 when he was a member of the Governor's Council of Revision)).

${ }^{180}$ Id. (quoting ThOMAS M. COOLEY, TREATISE ON THE CONSTITUTIONAL LIMITATIONS WHICH REST UPON THE LEGISLATIVE POWER OF THE STATES IN THE AMERICAN UNION 389-97 (3d ed. 1874)).

${ }^{181} \mathrm{Id}$. at 259-60 (quoting ThOMAS M. COOLEy, TREATISE ON THE CONSTITUTIONAL LiMITATIONS WHICH REST UPON THE LEGISLATIVE POWER OF THE STATES IN THE AMERICAN UNION 392 (3d ed. 1874).

${ }^{182}$ Id. at 260 (quoting THOMAS M. COOLEY, TREATISE ON THE CONSTITUTIONAL LiMITATIONS WHICH REST Upon the Legislative POWER Of THE STATES IN THE AMERICAN UniON 393 (3d ed. 1874).

183 Barbier v. Connolly, 113 U.S. 27, 32 (1885).
} 
Importantly, the purpose of the law cannot be to grant a special benefit to a particular individual or group-the purpose must be to promote an important public purpose. The Fourteenth Amendment thus only allows laws that discriminate if the laws "are designed, not to impose unequal or unnecessary restrictions upon any one, but to promote, with as little individual inconvenience as possible, the general good." ${ }^{184}$ This idea was expressed as well in Corfield $v$. Coryell where Justice Washington indicated that fundamental rights could always be trumped by just laws enacted for the good of the whole people. ${ }^{185}$

Opposition to class legislation and the need for generality in lawmaking were expressed in state court decisions throughout the country in the 1820 s to the 1860 s. In 1824 , the Maine Supreme Court stated, "it can never be within the bounds of legitimate legislation to enact a special law ... granting a privilege and indulgence to one man" that is not granted to "all other persons." ${ }^{186}$ Rather, laws should be "prescribed for the benefit and regulation of the whole community" because all individuals have "an equal right" to their "protection.", Similarly, in 1881 the Pennsylvania Supreme Court reasoned that "general laws are enacted, which bear . . . on the whole community, if they are unjust and against the spirit of the constitution, the whole community will be interested to procure their repeal." ${ }^{188}$

In an 1831 decision, the Tennessee Supreme Court of Errors struck down a law which prohibited suits from being brought by an Indian reservee if the suit was prosecuted for the benefit of another party. ${ }^{189}$ The state law applied only to a small amount of land that was established under treaties between the Cherokees and the U.S. government. Because the treaties

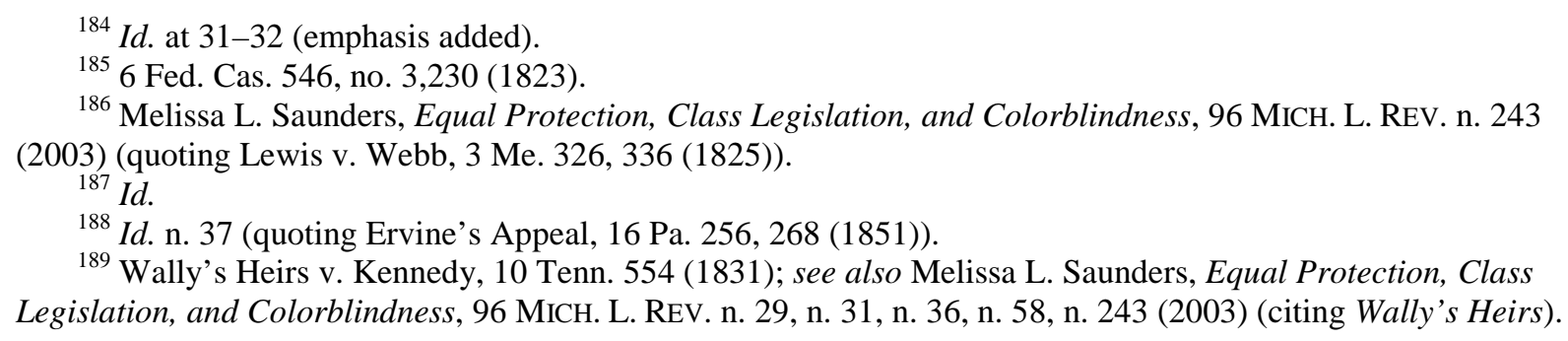


were secured to the reservees for the right of citizenship, they were entitled to the same constitutional protections as the citizens of the state. ${ }^{190}$ The court explained that "no free man shall be disseized of his freehold, or deprived of his property, but by the judgment of his peers or the law of the land." ${ }^{, 191}$ Further, "Every partial or private law which directly proposes to destroy or affect individual rights, or does the same thing by affording remedies leading to similar consequences, is unconstitutional and void." ${ }^{192}$ Since the law applied only to a small amount of land granted to reservees under the treaty, the court ruled that the law was unconstitutional and void as a partial law. ${ }^{193}$

In another Tennessee case in 1844, the state Supreme Court ruled that a law which allowed trustees of a particular trust to receive a donation made to an unincorporated association was void under the constitutional requirement that legislators may not suspend a general law for the benefit of particular individuals. ${ }^{194}$ The constitution said that "the legislature shall have no power to pass any law, for the benefit of individuals, inconsistent with the general laws of the land, nor to pass any law granting to any individuals rights, privileges, immunities, or exemptions other than such as may be by the same law extended to any member of the community who may be able to bring himself within the provisions of this law.”195

A similar view was presented in 1859 in Wisconsin; the state supreme court explained the need for generality in lawmaking in the course of striking down a law that taxed some property at a lesser rate than other property within a city. ${ }^{196}$ The court said:

The theory of our government is, that socially and politically, all are equal, and that special or exclusive, social or political privileges or immunities cannot be

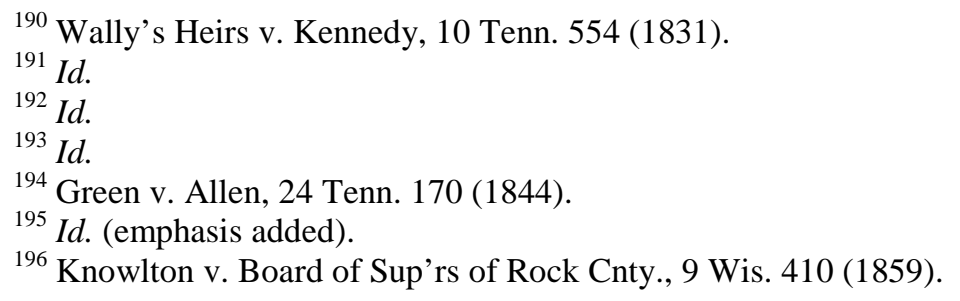


granted, and ought not to be enjoyed; and, therefore, the burdens of supporting the government should be borne equally by all the individuals composing it, in proportion to the benefits conferred. To give permanency and force, and secure its rigid observance, limitations or restrictions were introduced into the constitution of this state. ${ }^{197}$

Likewise, in an 1859 Ohio Supreme Court case, the dissent argued against a law which established separate schools for blacks and whites. ${ }^{198}$ On caste-based legislation, he argued that it is:

the inveterate vice of absolute governments, is inconsistent with the theory and spirit of a free and popular government like ours; asserting in its bill of rights the equality of all men. A free government like ours must be presumed, so far as practicable, to avoid class legislation; and rather to trust and favor the natural liberty and right of individuals to form and regulate their own social circles and classification according to their respective predilections and prejudices. ${ }^{199}$

Recognizing a change in the law over the past decade, the judge concluded that "it seems to me alike unwise and wholly out of character with the progress, the general intelligence, and liberality of the age at this time-more than ten years after the repeal of the 'black laws,' . . to give an extent and effect to those disabling statutes."200

In a habeas corpus proceeding in the Supreme Court of Georgia in 1859, the court ruled that a law requiring a license to sell goods in the market—which the court described as class legislation—did not prohibit a man from selling goods outside the market. ${ }^{201}$ The judge remarked that "Excessive legislation—-the vice of all free governments—is, perhaps, the fault of the State. Through haste, inadvertence, and other causes . . . class legislation is to be found frequently upon our statute book[s]. Something should be done to arrest this evil. The dearest

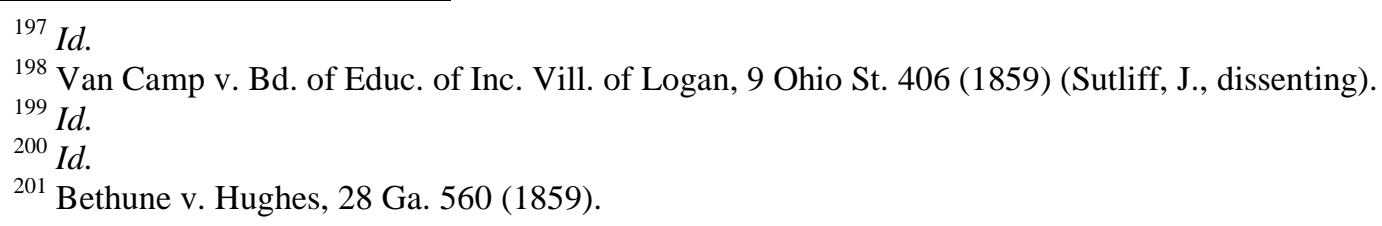


rights of the people are jeopardized." ${ }^{202}$ Further, "A peaceable citizen, who discharges punctually all his public duties, and respects scrupulously the rights of others, should be left free and untrammeled as the air he breathes, in the pursuit of his business and happiness" and that "best sympathies of [his] heart are, and always will be, interested for one who is, or may be, incarcerated, because, in the proud consciousness of a freeman, he claims the right to offer for sale ... any commodity he may possess, the traffic in which is not forbidden by the laws of the land." 203

By the 1840's and 1850's, opposition to special and partial laws was so widespread among Jacksonian Democrats that even their Abolitionist opponents began to borrow the Jacksonian idea. Abolitionists argued — quite rightly—-that the Slave Power in the South had seized the government and was using it to create an oligarchy that oppressed African Americans. The famous abolitionist Lysander Spooner is an example of someone who understood this connection. Spooner was both an early opponent of monopolies - as evidenced in his opposition to the federal postal monopoly in the $1840{ }^{2}{ }^{204}$ —and one of the most outspoken abolitionists during this time period. Spooner wrote in The Unconstitutionality of Slavery, in 1860, that the institution of slavery is contrary to the Constitution. Further, the Constitution should be read to be consistent throughout and that "the right to send and receive letters by post [which he believed to be the case], is a right inconsistent with the idea of a man's being a slave.”205

The Abolitionists' Slave Power argument was attractive to many erstwhile Jacksonian Democrats and a number of Jacksonian Democrats eventually joined the antislavery cause. For

\footnotetext{
${ }^{202} I d$.

${ }^{203} \mathrm{Id}$.

${ }^{204}$ See pages ___ infra.

${ }^{205}$ Lysander Spooner, The Unconstitutionality of Slavery (1860), available at http://oll.libertyfund.org/index.php?option=com_staticxt\&staticfile=show.php\%3Ftitle=2206\&layout=html.
} 
example, Representative Norton Townshend, a Democrat from Ohio, spoke out against slavery in the following terms on the House floor:

I protest against all these interpolations into the Democratic creed, and against any such interpretation of Democracy as makes it the ally of slavery and oppression. Democracy and slavery are directly antagonistic. Democracy is opposed to caste, slavery creates it; Democracy is opposed to special privileges; slavery is but the privilege specially enjoyed by one class-to use another as brute beasts and take their labor without wages; Democracy is for elevating the laboring masses to the dignity of perfect manhood; slavery grinds the laborer into the very dust ... slavery is but the extreme of class legislation .... slavery is nothing more than the privilege some have of living out of others ... ${ }^{206}$

Another representative, associated at times with the Democratic Party but who allied himself with the Radical Republicans, John F. Farnsworth said, "As a moral being, as a man, I hate slavery in the States of this Union as I hate serfdom in Russia - which, by the way, is about to be abolished in that Empire, while we are quarrelling over the extension of slavery in this—just as I hate caste in India—just as I hate oppression everywhere.”207 Indeed, as Saunders explains, by the mid-1850s "thousands of these heirs of the Jacksonian political tradition left the Democratic Party for the Republican Party, driven by the belief that the former was 'no longer the champion of popular rights that it had been in Jackson's day' but had become 'the tool of a slave holding oligarchy.'”208 The radical Republican, Senator Sumner, explained the connection between slavery and monopoly as follows:

The Rebellion began in two assumptions. . . . first, the sovereignty of the States, with the pretended right of secession; and, secondly, the superiority of the white race, with the pretended right of Caste, Oligarchy, and Monopoly, on account of color. ... The second showed itself at the beginning, when South Carolina alone among the thirteen States allowed her Constitution to be degraded by an exclusion on account of color .... 209

${ }^{206}$ 32nd Congress 1st Session Appendix Cong. Globe 713 (1852) (statement of Norton S. Townshend).

207 36th Congress Special Session Cong. Globe 120 (1861) (Statement of Representative John F. Farnsworth).

${ }^{208}$ Melissa L. Saunders, Equal Protection, Class Legislation, and Colorblindness, 96 MICH. L. REV. 245, 266 (2003)

${ }^{209}$ Cong. Globe, 39th Cong., 1st Sess., 686 (1866) (Statement of Senator Charles Sumner). 
In fact, for Sumner, slavery was a system of caste:

A Caste cannot exist except in defiance of the first principles of Christianity and the first principles of a Republic. It is heathenism in religion and tyranny in government. The Brahmins and the Sudras in India, from generation to generation, have been separated, as the two races are now separated in these States. If a Sudra presumed to sit on a Brahmin's carpet, he was punished with banishment. But our recent rebels undertake to play the part of the Bramhins, and exclude citizens, with better title than themselves, from essential rights, simply on the ground of Caste, which, according to its Portuguese origin, casta, is only another term for race. ${ }^{210}$

Sumner went as far as to propose legislation banning all systems of caste, class, and monopoly in the Senate in 1866 . The language he used for the proposed statute was extremely broad:

There shall be no Oligarchy, Aristocracy, Caste, or Monopoly invested with peculiar privileges and powers, and there shall be no denial of rights, civil or political, on account of color or race anywhere within the limits of the United States or the jurisdiction thereof; but all persons therein shall be equal before the law. ${ }^{211}$

The connections between the Abolitionist movement, disenfranchisement of blacks, and opposition to class-based laws generally was drawn in a series of 1857 Maine Supreme Court decisions that were reached on the same day. These cases rejected the Supreme Court's decision in Dred Scott and held that free black men have the right to vote as citizens of the state of Maine. The decisions in Maine were in response to an interrogatory from the Maine State Senate that asked whether "freed colored persons, of African descent, having a residence established in some town in this state ... are men, women, children, paupers, persons under guardianship, or unnaturalized foreigners" and, thus, whether they have the right to vote. ${ }^{212}$

In an opinion from Judge Appleton, the court makes clear its views on Dred Scott and its reading of the Privileges and Immunities clause in Article IV. ${ }^{213}$ Judge Appleton began by

\footnotetext{
${ }^{210}$ Id. at $683-84$.

${ }^{211}$ Id. at $115 ; 1287$.

${ }^{212}$ Opinion of the Supreme Judicial Court, 44 Me. 507 (1857).

213 Opinion of Judge Appleton, 44 Me. 521 (1857).
} 
proclaiming that "The constitution of Maine recognizes as its fundamental idea, the great principle upon which all popular governments rest-the equality of all before the law. It confers citizenship and entire equality of civil and political rights upon all its native born population.”214 The court relied on historical evidence: original state constitutions, the Declaration of Independence, and state court decisions recognizing the freedom of inhabitants without regard to ancestry or color. ${ }^{215}$ It concluded that "colored freemen were regarded as citizens, and entitled to the right of suffrage, in most of the states, during the whole period of the revolution." ${ }^{216}$ It said as well that Dred Scott was not "obligatory" on the state courts. ${ }^{217}$ Since the federal constitution does not impose restrictions as to who might become citizens of a state, and because the people of Maine did not make distinctions on the basis of status or class, but instead "formed a constitution upon principles of the purest democracy, making no distinctions and giving no preferences, but resting upon the great idea of equality before the law," black men must and do have the right to vote. ${ }^{218}$ As Judge Davis also explained in a third decision, if the federal government were really able to define certain classes as being either citizens or as being noncitizens under the guise of construing Article IV's Privileges and Immunities Clause, then the federal government would effectively be "establishing privileged classes" which is "in violation of [the Constitution's] letter and spirit."219

Immediately after the end of the Civil War in 1865 and 1866, many Southern States adopted a set of racially discriminatory laws that came to be known as the Black Codes. These

\footnotetext{
${ }^{214} \mathrm{Id}$.

${ }^{215} \mathrm{Id}$.

${ }^{216} \mathrm{Id}$.

${ }^{217} \mathrm{Id}$.

${ }^{218} \mathrm{Id}$.

${ }^{219}$ Opinion of Judge Davis, 44 Me. 576 (1857).
} 
laws limited the rights to contract, own property, travel, and testify in court of all the former slaves. The Black Codes:

perpetuated or created many distinctions in the criminal law by applying unequal penalties to Negroes for recognized offenses and by specifying offences for Negroes only. Laws which prohibited Negroes from keeping weapons or from selling liquor were typical of the latter. Examples of discriminatory penalties were the laws which made it a capital offence for a Negro to rape a white woman or to assault a white woman with intent to rape .... In addition to the discrimination of the criminal laws, post-war black codes hedged in the Negroes with a series of restraints on their business dealings of even the simplest form. Though in many states the Negro could acquire property, Mississippi put sharp limitations on that right. But most restrictive were the provisions concerning contracts for personal service. Many statutes called for specific enforcement of labor contracts against freedmen, with provisions to facilitate capture should a freedman try to escape. Vagrancy laws made it a misdemeanor for a Negro to be without a longterm contract of employment; conviction was followed by a fine, payable by a white man who could then set the criminal to work for him until the benefactor had been completely reimbursed for his generosity. ${ }^{220}$

The Black Codes were widely criticized as being a forbidden form of class legislation which sought a monopoly over black labor. For example, in an editorial in the Chicago Tribune in 1866, the author warned that "if the several States can practi[c]e class legislation, as between whites and blacks ... they can also create class distinctions in the future between rich and poor, or between any other divisions of society.,"221

The 39th Congress's response to the Black Codes was the Civil Rights Act of 1866. The Civil Rights Act required that "there shall be no discrimination in civil rights or immunities among the inhabitants of any State or Territory of the United States on account of race, color, or previous condition of slavery.” Despite the broad language, it was explained by the bill's drafters that the Act only applied to "civil" rights enumerated in the Bill of Rights (and not "political" rights, such as the right to vote). This included the right to make and enforce

\footnotetext{
${ }^{220}$ John Frank \& Robert Munro, The Original Understanding of the Equal Protection of the Laws, 1972 WASH. U. L. Q. 421, 445-46.

${ }^{221}$ Editorial, Class Legislation, Chi. Trib., Jan. 12, 1866, at 2.
} 
contracts, sue, be parties, to own land and personal property, and be subject to the same criminal punishments.

After the Civil Rights Act of 1866 was passed, however, there was still fear among supporters of Reconstruction that the Civil Rights Act would be struck down as an unconstitutional exercise of congressional power to enforce the Thirteenth Amendment. As a solution, Congress began working on the Fourteenth Amendment to write the Civil Rights Act into the Constitution. This would protect it from challenge in the courts or from a later Congress changing the law. However, the purpose of the Fourteenth Amendment also went beyond the protections under the Civil Rights Act. As Melissa Saunders explains in her aforementioned article, the support for legislation to guarantee the civil rights for blacks among the Republicans and Jacksonian Democrats was primarily on opposition to class legislation and the spirit of monopoly more generally. ${ }^{222}$ As James Wilson, Chair of the House Judiciary Committee, said, there is no room for class legislation in a democratic government-laws aimed "against [one class] for the purpose of advantaging the interests of [another]” were prohibited. ${ }^{223}$ The Black Codes themselves were objectionable because they violated Blackstone's maxim that "the restraints introduced by the law should be equal to all” ${ }^{224}$ as Senator Lyman Trumbull, cosponsor of the Civil Rights Act, explained. Thus, the purpose went beyond discrimination against blacks and included all class-based legislation.

Popular accounts of the Amendment also understood it to be far reaching. For example, the San Francisco Daily Evening Bulletin said it was an "opportunity . . . for the masses to break

${ }^{222}$ Melissa L. Saunders, Equal Protection, Class Legislation, and Colorblindness, 96 MiCH. L. REV. 245, 26970 (2003).

${ }^{223}$ Cong. Globe, 39th Cong., 1st Se. 2766 (1866).

${ }^{224}$ Id. at 474. 
down the domination of caste and aristocracy” ${ }^{225}$ and the Boston Daily Advertiser described its purpose as "compel[ling] the States to . . . throw the same shield over the black man as over the white, over the humble as over the powerful." ${ }^{226}$ Similarly, the Cincinnati Commercial said the Amendment constitutionalized "the great Democratic principle of equality before the law" and invalidated all "legislation hostile to any class." ${ }^{227}$ As Steven Calabresi and Julia Rickert argue:

By connecting the old-world problems of aristocracy and feudalism with race discrimination and caste in America, these commentators provide more evidence that the American public conceived of the word caste at a higher level of generality than the word race. The Framers and ratifiers of the Fourteenth Amendment would have understood it to ban European feudalism or the Indian caste system, as well as the special-interest monopolies that so outraged Jacksonian Americans. ${ }^{228}$

The meaning of the Privileges or Immunities clause itself grew out of the Privileges and Immunities clause of Article IV. Article IV was well-understood at the time the Fourteenth Amendment was adopted to be a ban on discrimination against nonresidents of a state, as the Supreme Court laid out in the Corfield case discussed above. Similarly, then, the Fourteenth Amendment's Privileges or Immunities clause was a ban on discrimination, but in this case it was a ban on class or caste discrimination. As Steven Calabresi has explained elsewhere, ${ }^{229}$ the text of the amendment's references to "privileges or immunities" together with the verb "abridge" is a legal term of art. The Fourteenth Amendment's use of the word "abridge" makes this point clearer. Abridge means to shorten or abbreviate. It is widely accepted that the Fourteenth Amendment banned the Black Codes, which lessened or abridged the civil rights of African Americans compared to whites. The Black Codes would fall because they were an

\footnotetext{
225 Southern Experiment, S.F. DAILY EvENING BuLl., Nov. 9, 1866, at 1.

${ }^{226}$ Editorial, Reconstruction, Bos. DAILY ADVERTISER, May 24, 1866, at 1.

${ }^{227}$ The Constitutional Amendment, CinCinNATi CoM., June 21, 1866, at 4.

${ }^{228}$ Steven G. Calabresi \& Julia T. Rickert, Originalism and Sex Discrimination, 90 TEX. L. REV. 1, 36 (2011).

${ }^{229}$ Steven G. Calabresi \& Julia T. Rickert, Sex Equality and Original Meaning: A Response to Jack Balkin, Dec. 15, 2011, http://balkin.blogspot.com/2011/12/sex-equality-and-original-meaning.html.
} 
example of the Slave Power trying to perpetuate itself by giving its supporters monopoly power over the lives of the freed African-Americans. In fact, President Andrew Johnson stated that the Black Codes were objectionable because “'there is no room for favored classes or monopolies,' for 'the principle of our Government is that of equal laws,' which 'accord equal justice to all men, special privileges to none.” 230 This is the same as his view regarding slavery, which he said was “a monopoly of labor.",231 Thus, "abridge” is meant to be synonymous with discrimination, similar to its use in the Fifteenth Amendment, which says that "The right of citizens of the United States to vote shall not be denied or abridged by the United States or by any State on account of race, color, or previous condition of servitude.”232

The intellectual, legislative, and judicial history leading up to the adoption of the Fourteenth Amendment thus confirms what the text of Section One of that amendment implies. The Fourteenth Amendment is a ban not only of racially discriminatory laws but also of all classbased legislation and certainly of any legislation that set up a system of caste or monopoly. This included the right to be free from unreasonable government interference into one's trade. Representative John Bingham, the primary author of the privileges or immunities clause, understood the clause to protect "the liberty ... to work in an honest calling and contribute by

${ }^{230}$ Melissa L. Saunders, Equal Protection, Class Legislation, and Colorblindness, 96 Mich. L. ReV. 245, 272 (2003) (quoting 2 A COMPILATION OF THE MESSAGES AND PAPERS OF THE PRESIDENTS: 1789-1897, at 361-62 (James D. Richardson ed., 1896) (emphasis added)).

${ }^{231}$ As President Johnson explained in full in 1866:

Slavery was essentially a monopoly of labor, and as such locked the States where it prevailed against the incoming of free industry. Where labor was the property of the capitalist, the white man was excluded from employment, or had but the second best chance of finding it; and the foreign emigrant turned away from the region where his condition would be so precarious. With the destruction of the monopoly, free labor will hasten from all parts of the civilized world to assist in development various and immeasurable resources which have hitherto lain dormant ... . The removal of the monopoly of slave labor is a pledge that those regions will be peopled by a numerous and enterprising population, which will vie with any in the Union.

Cong. Globe, 39th Cong., 1st Sess., 3 (1866) (Message of President Andrew Johnson).

${ }^{232}$ U.S. CONST. amend. XV. 
your toil in some sort to the support of yourself, to the support of your fellowmen, and to be secure in the enjoyment of the fruits of your toil." ${ }^{\text {233 }}$ Similarly, another representative questioned during the amendment’s drafting: "Has not every person a right, to carry on his own occupation, to secure the fruits of his own industry, and appropriate them as best suits himself . . . ?’234 Thus, grants of monopoly would certainly be prohibited under Section One unless they were somehow just laws enacted for the general good of the whole people. The original public meaning of the words of Section One of the Fourteenth Amendment in 1868 would have been understood to be a ban on caste, monopoly, and on systems of class legislation. The Amendment required some degree of generality in law-making.

\section{Economic Liberty Cases: Slaughter-House, Lochner, \& the New Deal Cases}

The meaning of the Fourteenth Amendment immediately became the subject of controversy in 1873 in the Slaughter-House Cases. In that case, a group of Louisiana butchers challenged the constitutionality of a state statute that incorporated and granted a twenty-five year slaughterhouse monopoly to the Crescent City Live-Stock Landing \& Slaughter-house Company. The butchers challenged the statute as violating the U.S. Constitution and in particular the Thirteenth and Fourteenth amendments. ${ }^{235}$ Importantly, the butchers also argued at length that the Louisiana slaughtering monopoly violated the common law rule of Darcy and the Statute of Monopolies. In fact, counsel for the butchers read Sir Edward Coke's report of Darcy to the Court, and cited it in full in the brief. ${ }^{236}$ Emphasizing that the English creation of monopolies had helped to give rise to the American Revolution, the butcher's counsel then pointed out:

It was from a country which had been thus oppressed by monopolies that our ancestors came. And a profound conviction of the truth of the sentiment ... that

\footnotetext{
${ }^{233}$ TIMOTHY SANDEFUR, THE RIGHT TO EARN A LiVING 41 (2010).

${ }^{234} \mathrm{Id}$.

${ }^{235}$ Slaughter-House Cases, 83 U.S. (16 Wall.) 36, 48-49 (1872) (argument of Campbell and Fellows).

${ }^{236} I d$. at 48 .
} 
every man has a right to his own faculties, physical and intellectual, and that this is a right, one of which no one can complain, and no one deprive him-was at the bottom of the settlement of the country by them. Accordingly, free competition in business, free enterprise, the absence of all exactions by petty tyranny, of all spoliation of private right by public authority-the suppression of sinecures, monopolies, titles of nobility, and exemption from legal duties-were exactly what the colonists sought for and obtained by their settlement here, their long contest with physical evils that attended the colonial condition, their struggle for independence, and their efforts, exertions, and sacrifices since. ${ }^{237}$

Counsel for the butchers explained that this common law right was recognized by state courts in several states before the adoption of the Fourteenth Amendment in 1868. For example, in 1856, Connecticut's Supreme Court of Errors relied on Darcy v. Allen and the Statute of Monopolies to strike down a law which granted a franchise to a corporation giving it an exclusive privilege to use streets to lay gas pipe. ${ }^{238}$ In another case in 1837, the New York Chancery Court refused to enforce a city ordinance which would have prohibited a manufacturer of pressed hay from erecting a wooden frame building while allowing another manufacturer to do so. ${ }^{239}$ And in a case with facts remarkably similar to those in Slaughter-House, the Supreme Court of Illinois struck down a Chicago ordinance which limited the ability to slaughter animals to only one firm. ${ }^{240}$ In reference to the city's municipal laws, the court said that such a law "impairs the rights of all other persons, and cuts them off from a share in not only a legal, but a necessary business.”241 Additionally, such laws “must be reasonable, and such as are vexatious, unequal or oppressive, or are manifestly injurious to the interest, of the corporation, are void. And of the same character are all by-laws in restraint of trade, or which necessarily tend to

\footnotetext{
${ }^{237} \mathrm{Id}$.

${ }^{238}$ The Norwich Gaslight Company v. The Norwich City Gas Company, 25 Conn. 19 (1856) (cited by the butchers' counsel at Slaughter-House Cases, 83 U.S. at 48).

${ }^{239}$ The Mayor of the City of Hudson v. Thorne, 7 Paige Ch. 261 (N.Y. Ch. 1838) ("the common council cannot make a by-law which shall permit one person to carry on the dangerous business, and prohibit another, who has an equal right, from pursuing the same business") (cited by the butchers' counsel at Slaughter-House Cases, 83 U.S. at 48).

${ }^{240}$ City of Chicago v. Rumpff, 45 Ill. 90 (1867) (cited by the butchers' counsel at Slaughter-House Cases, 83 U.S. at 48).

${ }^{241} I d$.
} 
create a monopoly." 242 As Justice Field acknowledged in his dissenting opinion, "In all these cases there is a recognition of the equality of right among citizens in the pursuit of the ordinary avocations of life, and a declaration that all grants of exclusive privileges, in contravention of this equality, are against common right, and void."243 Significantly, while none of the abovementioned states had provisions in their constitutions prohibiting monopolies, the local ordinances were still struck down.

The butchers' counsel also argued that the privileges or immunities clause of the Fourteenth Amendment embodied an unenumerated right to be free from monopolies which went beyond Darcy v. Allen and the Statute of Monopolies. As the butchers' counsel explained, the rights protected under the privileges or immunities clause "are undoubtedly the personal and civil rights which usage, tradition, the habits of society, written law, and the common sentiments of people have recognized as forming the basis of the institutions of the country."244

Justice Field, in his dissenting opinion for four members of the Court, agreed with the butchers. Citing Corfield v. Coryell, discussed in Part I.B.2 above, Justice Field recognized Justice Washington's definition of the term "privileges and immunities" as encompassing a number of unenumerated rights that he deemed fundamental. Thus, since Article IV's privileges and immunities clause prohibited discriminatory legislation against non-residents, the Fourteenth Amendment likewise functioned to prohibit such discriminatory class legislation by residents of one state against other residents of the same state:

What the clause in question did for the protection of the citizens of one State against hostile and discriminating legislation of other States, the fourteenth amendment does for the protection of every citizen of the United States against hostile and discriminating legislation against him in favor of others, whether they reside in the same or in different States. If, under the fourth article of the

\footnotetext{
${ }^{242}$ Id. (emphasis added).

243 Slaughter-House Cases, 83 U.S. at 109 (Field, J., dissenting).

${ }^{244}$ Id. at 55 (argument of the butcher's counsel).
} 
Constitution, equality of privileges and immunities is secured between citizens of different States, under the fourteenth amendment, the same equality is secured between citizens of the United States. ${ }^{245}$

Justice Field argued that Justice Washington's definition of privileges and immunities in Corfield v. Coryell should be taken as definitively informing the meaning of the Privileges or Immunities Clause of the Fourteenth Amendment. Justice Field then explained why he thought that the right to be free from partial laws was a fundamental right of United States citizens:

This equality of right, with exemption from all disparaging and partial enactments, in the lawful pursuits of life throughout the whole country, is the distinguishing privilege of citizens of the United States. To them, everywhere, all pursuits, all professions, all avocations are open without other restrictions than such as are imposed equally upon all others of the same age, sex, and condition .... This is the fundamental idea upon which our institutions rest, and unless adhered to in the legislation of the country our government will be a republic only in name. The fourteenth amendment, in my judgment, makes it essential to the validity of the legislation of every State that this equality of right should be respected. ${ }^{246}$

Justice Field also quotes Adam Smith's The Wealth of Nations at length (as did the butchers in their briefs). He emphasized the idea that a person's labor is his property and is the foundation

for all other property:

"The property which every man has in his own labor," says Adam Smith, "as it is the original foundation of all other property, so it is the most sacred and inviolable. The patrimony of the poor man lies in the strength and dexterity of his own hands; and to hinder him from employing this strength and dexterity in what manner he thinks proper, without injury to his neighbor, is a plain violation of this most sacred property. It is a manifest encroachment upon the just liberty both of the workman and of those who might be disposed to employ him. As it hinders the one from working at what he thinks proper, so it hinders the others from employing whom they think proper." 247

${ }^{245} I d$. at $100-01$ (Field, J., dissenting).

${ }^{246} I d$. at 109-10 (Field, J., dissenting).

${ }^{247}$ Id. at 111 (quoting ADAM SMITH, AN INQUIRY INTO THE NATURE AND CAUSES OF THE WEALTH OF NATIONS, b. 1, ch. 10, part 2 (1776)); see also Supplemental Brief and Points of Plaintiffs in Error, Slaughter-House Cases, 83 U.S. 36, 1871 WL 14607, at *5-*6 (1871) (quoting the same passage from Wealth of Nations). 
Thus, in a sense Justice Field's dissenting opinion merged the previously opposing views in the Charles River Bridge case, discussed in Part I.B.2 above. For Chief Justice Taney, what was offensive in Charles River Bridge was the state's grant of a monopoly to the bridge company. However, for Justice Story, it was paramount to protect the bridge company's property right in what he saw as its contract with the state. Justice Field folded both of these views into his dissenting opinion in The Slaughter-House Cases, recognizing both the right to be free from monopolies and the right to one's property in his or her labor.

Nevertheless, a majority of the Supreme Court in The Slaughter-House Cases rejected the butchers' arguments, holding that the state granted monopoly was constitutional and nearly writing the Privileges or Immunities Clause out of the Fourteenth Amendment. ${ }^{248}$ In his opinion for the Court, Justice Miller limited the Privileges or Immunities Clause to apply only to those rights which "own their existence to the Federal government, its National character, its Constitution, or its laws.” This included things like the ability to assert claims against one's government, free access to seaports, protection while on the high seas and when within the jurisdiction of a foreign government. ${ }^{249}$

Interestingly, Louisiana later amended its constitution to ban monopolies like the Slaughter-House monopoly. The monopolist butchers, who had won in federal court, challenged the amendment to the state constitution under the Contracts Clause- -just as the Charles River Bridge Company had done thirty-five years earlier in Charles River Bridge v. Warren Bridge. Once again the U.S. Supreme Court held that a state could abolish a monopoly without violating the Contracts Clause, so it upheld in 1884 Louisiana's constitutional amendment, eliminating the

\footnotetext{
${ }^{248}$ See, e.g., Steven G. Calabresi, Lawrence, the Fourteenth Amendment, and the Supreme Court's Reliance on Foreign Constitutional Law: An Originalist Reappraisal, 65 OHIO ST. L.J. 1097, 1108 (2004) (stating that, "The Privileges or Immunities Clause was gutted by the Supreme Court in 1873 in the Slaughterhouse Cases, but for a good originalist like me that does not matter.”).

${ }^{249}$ Slaughter-House Cases, 83 U.S. at 80.
} 
butchers' slaughtering monopoly. ${ }^{250}$ The Slaughter-House dissenters returned to their arguments in Slaughter-House, again arguing that the grant of monopoly violated the Fourteenth Amendment and Darcy in the first place. However, the majority ruled on a narrower ground that Louisiana did not have the power to make the state-granted monopoly irrevocable. ${ }^{251}$

While the Slaughter-House Cases closed a door on reading the Privileges or Immunities Clause to strike down grants of economic privilege and of monopoly, and other cases, such as Munn v. Illinois in 1877 and Barbier v. Connolly in 1895, further weakened the protection of economic liberty and constrains on the state police power under the Fourteenth Amendment ${ }^{252}$ later Court decisions reached different conclusions. The idea that the Fourteenth Amendment bans class legislation and embodies the protection of economic rights was revived at the turn of the twentieth century with the 1897 case, Allgeyer v. Louisiana, ${ }^{253}$ and in 1905 in Lochner $v$. New York. ${ }^{254}$ Justice Field's Slaughter-House dissent clearly inspired the Supreme Court majority in both Allgeyer and Lochner. As one legal scholar wrote, "In 1873, a bare majority resisted the dissenters' appeal to social compact and natural law and vested rights ideology; but a generation later, a new majority embraced substantive due process.”255 In Lochner, Justice Rufus Peckham held that a law which limited bakers' hours to ten-hour days and sixty-hour

\footnotetext{
${ }^{250}$ Butchers' Union Slaughter-House \& Live-Stock Landing Co. v. Crescent City Live-Stock Landing \& Slaughter-House Co., 111 U.S. 746 (1884).

${ }^{251}$ Id. at 752-54; id. at 761-64 (Bradley, J., concurring); id. at 755-56 (Field, J., concurring); see also Richard A. Epstein, Of Citizens and Persons: Reconstructing the Privileges or Immunities Clause of the Fourteenth Amendment, 1 N.Y.U. J. L. \& LIBERTY 334, 338-39 (2005).

${ }^{252}$ Barbier v. Connolly, 113 U.S. 27 (1895) (holding that the Fourteenth Amendment did not constrain the state's police power); Munn v. Illinois, 94 U.S. 113 (1877) (holding that the Fourteenth Amendment did not prohibit the state from regulating businesses involved in serving the public interest).

253165 U.S. 578 (1897) (“The 'liberty' mentioned in [the Fourteenth] amendment means not only the right of the citizen to be free from the mere physical restraint of his person, as by incarceration, but the term is deemed to embrace the right of the citizen to be free in the enjoyment of all his faculties, to be free to use them in all lawful ways, to live and work where he will, to earn his livelihood by any lawful calling, to pursue any livelihood or avocation, and for that purpose to enter into all contracts which may be proper, necessary, and essential to his carrying out to a successful conclusion the purposes above mentioned.”)

${ }_{254} 198$ U.S. 45 (1905).

${ }^{255}$ Frank R. Strong, Unraveling the Threads of Substantive Due Process, in POWER AND POLICY IN QUEST OF LAW (1985) (quoting GERALD GUNTHER, CASES AND MATERIALS ON CONSTITUTIONAL LAW 507 (10th ed. 1980)).
} 
weeks violated liberty of contract, which he said was protected by the Due Process Clause of the Fourteenth Amendment. Justice Peckham's view was that the purpose of the regulation was to equalize bargaining power between employers and employees, and that it was not a just law enacted for the good of the whole people and to promote health and safety concerns as was claimed by the state. Lochner rendered at least some forms of redistribution of wealth constitutionally suspect, ${ }^{256}$ and the opinion seemed to imply that the sixty-hour work week for bakers was motivated by a desire to protect big bakeries from competition from smaller, harderworking immigrant competitors. ${ }^{257}$ There was thus an element of state enforced special privilege or monopoly to the case. As a result of the Lochner opinion, a wave of "liberty of contract" cases were decided in federal and state courts. Ultimately, the whole period of time between 1905 and 1937 became known as the Lochner era.

Justice Peckham's opinion in Lochner, like the Slaughter-House dissent, became famous for its robust conception of constitutionally protected economic liberties. One scholar has argued that many of the laws struck down during the Lochner era were in fact the result of rent-seeking behavior. ${ }^{258}$ Both the Lochner decision and Slaughter-House dissent show an interest in one's right to freely work. But, the decision in Lochner can also be distinguished from the decision in the Slaughter-House Cases. Whereas Lochner announced a right to liberty of contract in all contexts, the Slaughter-House Cases dealt with a different and arguably distinct issue-the Fourteenth Amendment's prohibition on grants of monopoly or special privilege. And while some laws aimed at restricting economic liberty may be discriminatory class-based legislation,

\footnotetext{
${ }^{256}$ Michael Kent Curtis, Resurrecting the Privileges or Immunities Clause and Revising the Slaughter-House Cases without Exhuming Lochner: Individual Rights and the Fourteenth Amendment, 38 B.C. L. REV. 1, 92 (1996).

${ }^{257}$ For a good history of the case, see DAVID E. BERNSTEIN, REHABILITATING LOCHNER: DEFENDING INDIVIDUAL RIGHTS AGAINST PROGRESSIVE REFORM (2011).

${ }^{258}$ Douglas W. Kmiec, Property and Economic Liberty as Civil Rights: The Magisterial History of James W. Ely, Jr., 52 VAND. L. REV. 737, 740 (1999).
} 
such as exemptions for one industry and not another, it is not always the case that laws that restrict economic liberty are class based.

In the wake of the Great Depression and of President Franklin D. Roosevelt's New Deal, the Supreme Court eventually retreated from the holding and opinion in Lochner, and it rejected the idea that the Constitution protected a broad liberty of contract. First, Lochner was significantly weakened in 1934 when the Supreme Court relaxed the level of scrutiny it would apply in cases of economic regulation in Nebbia v. New York. ${ }^{259}$ Although the Supreme Court did not explicitly repudiate Lochner in Nebbia, it did hold that a price control setting the minimum price for milk was constitutional so long as it was nondiscriminatory and so long as it bore a reasonable relationship to a legitimate governmental purpose. ${ }^{260}$ In 1937, however, the Supreme Court radically repudiated Lochner in West Coast Hotel v. Parrish. In that case, the Supreme Court overturned a prior decision in Adkins v. Children's Hospital, and it upheld a state minimum wage law for women. ${ }^{261}$ The overturning of the Adkins decision was understood at the time and it in fact turned out to be a decisive repudiation of the whole Lochner line of cases.

Lochner had argued that an individual's liberty of contract could only be overcome by a reasonable exercise of the police power, and the Lochner Court evaluated reasonableness employing what readers today might call middle level scrutiny. ${ }^{262}$ The New Deal Supreme Court never abolished liberty of contract, but it dropped the level of scrutiny for state regulations of the police power from middle level scrutiny to a very deferential form of rational basis review. In its 1938 landmark holding in United States v. Carolene Products Co., the Supreme Court said that economic regulations would be presumed to be constitutional and would be upheld unless

\footnotetext{
259291 U.S. 502 (1934).

${ }^{260} \mathrm{Id}$.

261300 U.S. 379 (1937). This decision overturned Adkins v. Children's Hosp., 261 U.S. 525 (1923).

${ }^{262}$ A classic case employing middle level scrutiny is Craig v. Boren, 429 U.S. 190 (1978) (using middle level scrutiny for gender classifications).
} 
they were irrational even if the legislators' actual intent could not be proven. ${ }^{263}$ The Court dropped any interest whatsoever in determining whether a law created exclusive privileges or whether it reflected monopolistic class legislation. To the Carolene Products Court, all economic and social legislation was constitutional unless it discriminated against a discrete and insular minority, or closed off the channels of political change, or violated one of the first eight amendments in the Bill of Rights. Lochner was officially dead.

The new highly deferential rational basis review did not, however, immediately take hold in all the cases decided by the New Deal Supreme Court after 1937. As Professor Victoria Nourse explains in her book, In Reckless Hands: Skinner v. Oklahoma and the Near Triumph of Eugenics, the New Deal Supreme Court decided at least one important case using the old nineteenth century idea that the Fourteenth Amendment banned forms of arbitrary class legislation. ${ }^{264}$ In Reckless Hands recounts the use of eugenics in the 1920s and 1930s in asylums and prisons across in the United States, and the challenge to one eugenics law in a 1942 New Deal era case, Skinner v. Oklahoma. In Skinner, an Oklahoma law was challenged by a man who was sentenced to sterilization for being a repeat offender-he had stolen chickens and had also been convicted of armed robbery. The goal behind the Oklahoma statute, like other eugenics laws, was to "weed out” criminals from society by sterilizing repeat offenders who violated many criminal statutes. However, the Oklahoma statute provided exceptions for repeat violations of “prohibitory laws, revenue acts, embezzlement, or political offenses.”265

Clarence Darrow, the famous lawyer in the Scopes Monkey Trial, challenged Oklahoma's imposition of sterilization for robbers but not embezzlers saying it was not only

\footnotetext{
263304 U.S. 144 (1938).

${ }^{264}$ ViCTORIA F. NOURSE, In RECKLESS HANDS: SKINNER V. OKLAHOMA AND THE NEAR TRIUMPH OF EUGENICS 148-49 (2008); see also id. at 67-68; 126.

${ }^{265} \mathrm{Id}$.
} 
“"senseless and impudent,"” but also that it “impos[ed] a 'caste system.”,266 And, as another lawyer on the case argued, ${ }^{267}$

"I have wondered upon what rational basis the Legislature could have arrived at the conclusion that all those committing minor offenses would transmit to their progeny only vices; while the dishonest financier who appropriates trusting depositor' monies in the banks, or trustees who convert funds of confiding clients, and the saboteur, and the inciter of reason could spew from his loins only progeny blessed with virtues. The terms of the Act exclude from its penalties the Capones, the Ponzis, and the Benedict Arnolds.”268

The Supreme Court struck the law down in an opinion by Justice Douglas who reasoned-relying on the traditional pre-1937 understanding of the equal protection clauselaws which drew arbitrary lines were unconstitutional as a form of class legislation or a grant of an exclusive privilege. ${ }^{269}$ Nourse points out that arbitrariness was the "basic test for equal protection claims," even into the $1930 \mathrm{~s}^{270}$ and that laws which provided arbitrary exemptions for certain classes of people showed unconstitutional legislative favoritism. ${ }^{271}$

Class legislation, under the traditional understanding, is, as Nourse describes it, a "theory of failed governance.”272 In so arguing, Nourse draws correctly on the work of John Hart Ely in Democracy and Distrust. ${ }^{273}$ When a legislature draws a line between classes and provides exemptions, it favors the exempted group and discriminates against a class. In Skinner, the legislature protected those convicted of "high class” crimes, such as political or financial crimes, and burdened those guilty of "low class" crimes, such as chicken thieves, who were subject to sterilization if they were repeat offenders. ${ }^{274}$ Such laws create an ““aristocracy of crime,”, as one

\footnotetext{
${ }^{266}$ Id. at 56 (quoting Clarence Darrow, The Eugenics Cult, 8 AMER. MERCURY 130, 137 (1926)).

${ }^{267}$ Id. at $140-41$.

${ }^{268} \mathrm{Id}$.

${ }^{269}$ Id. at 148 (citing Skinner v. Oklahoma, 316 U.S. 535, 537-39 (1942)).

${ }^{270} \mathrm{Id}$. at 149 .

${ }^{271} \mathrm{Id}$.

${ }^{272} I d$.

273 JOHN HART ELY, DEMOCRACY AND DISTRUST: A THEORY OF JUDICIAL REVIEW (1980).

${ }^{274}$ Id.
} 
of Skinner's lawyers described it, by violating the "rule of generality" that was promoted by Thomas Cooley, who in turn had borrowed the same ideas from John Locke. As Cooley stated, there ought to be “'one law for rich and poor, for the favorite at court and the countryman at plough.’,275 As Nourse concludes in In Reckless Hands:

Contrary to conventional wisdom, Skinner fits standard legal models that put the prohibition of 'caste' legislation at the core of constitutional equality protections. The problem in Skinner was not with the distinction between chicken thieves and embezzlers simpliciter. The problem was with a criminal law as a rule of genetics, as a rule of blood — this was class made permanent ... Oklahoma's law created a line between privileged and unprivileged blood the sign of caste and aristocracy. ${ }^{276}$

Nourse recognizes that from 1868 until 1937, equal protection cases were usually about "property, taxes, and the right to work" rather than being about race or sex as they commonly are today. ${ }^{277}$ The traditional concern with class legislation, exclusive privileges, and monopoly "focused on exemptions in statutes as a proxy for political favoritism, on the theory that the law should be general, not partial." Such principles "reach[] as far back as the founding generation," and it is "clear" that the founders "aimed to prevent aristocracy, [and] rule by blood ... The theory of ‘class legislation' has always been about the fight against aristocracy.”278

Skinner v. Oklahoma in 1942 proved to be a temporary backward glance by the justices of the Supreme Court to the Nineteenth Century era when the Fourteenth Amendment was understood to ban class legislation and associated monopolies. The 1937 decision in West Coast Hotel and the 1938 decision in United States v. Carolene Products foretold the future of the Fourteenth Amendment which was to be about strict scrutiny of racial classifications and rational basis scrutiny for almost everything else. While not mentioning Lochner by name, the Court

\footnotetext{
${ }^{275}$ Id. (quoting Thomas M. CoOley, A TREATISE ON THE CONSTitutional Limitations 483 (1890)).

${ }^{276}$ Id. at $166-67$.

${ }^{277} \mathrm{Id}$. at 167.

${ }^{278} \mathrm{Id}$. at 167-68.
} 
made it clear that Lochner-style review for economic regulations was no longer available in its 1949 decision in Railway Express Agency v. New York. The Court said there that:

We do not sit to weigh evidence ... in order to determine whether the regulation is sound or appropriate; nor is it our function to pass judgment on its wisdom. We would be trespassing on one of the most intensely local and specialized of all municipal problems if we held that this regulation had no relation to the traffic problem. $^{279}$

The new standard of rational basis review of economic and social legislation, in fact "looked more like judicial abdication than judicial review."280

Williamson v. Lee Optical showed, in 1955, just how pathetic and meaningless the new rational basis review standard really was. The case held that if there was any hypothetical rationale that the justices could think up for a law, even if it was not the rationale used by the legislature, the law would be upheld. ${ }^{281}$ The facts in Williamson v. Lee Optical are troubling to say the least. An Oklahoma law prohibited anyone who was not a licensed optometrist or ophthalmologist from dispensing lenses or fitting lenses into frames except where there was a prescription from a licensed optometrist or ophthalmologist. The law also prohibited solicitation for sale of eyeglass frames by those did not have the required license.

The law was clearly an example of special interest legislation enacted to financially benefit optometrists and ophthalmologists by forcing patients to get an unwanted and unneeded eye exam every time they wanted to buy a new pair of glasses. Justice Douglas was at something of a loss for a rationale to support this law, but he finally hypothesized that maybe the law would encourage people to get needed eye exams. The law in Williamson v. Lee Optical Co.

279336 U.S. 106, 109 (1949).

${ }^{280}$ Paul E. McGreal, Alaska Equal Protection: Constitutional Law or Common Law?, 15 ALASKA L. REv. 209, 241 (1998); see also Hettinga v. United States, No. 11-5065 (D.C. Cir. 2011) (J. Brown, concurring), available at http://www.cadc.uscourts.gov/internet/opinions.nsf/70A27D44D7C03503852579DF004EF65F/\$file/11-50651368692.pdf (the court "abdicated its constitutional duty to protect economic rights completely" with the adoption of rational basis review.)

${ }^{281} 348$ U.S. 483 (1955). 
was an obvious example of special-interest legislation, and the fact the Supreme Court upheld it sent a signal that anything goes in the area of economic and social legislation. The Fourteenth Amendment may have been meant to bar caste, class based legislation, exclusive privileges, and monopolies, but after Williamson v. Lee Optical Co. that was all moot.

In 1963, in Ferguson v. Skrupa, the Court finally explicitly overruled Lochner, holding that "[t]he doctrine that prevailed in Lochner, Coppage, Adkins, Burns, and like cases—-that due process authorizes courts to hold laws unconstitutional when they believe the legislature has acted unwisely—has long since been discarded.” ${ }^{282}$ Ironically, just two years later, the Supreme Court reinvented substantive due process as to certain social matters, but not as to economic regulation, in Griswold v. Connecticut. ${ }^{283}$ This doctrine led ultimately to the Court's invalidation of abortion laws in Roe $v$. Wade ${ }^{284}$ and to its invalidation of sodomy laws in Lawrence $v$. Texas. ${ }^{285}$ The modern Supreme Court has shied away from economic substantive due process, but it has enforced the Takings Clause with a pre-1937 vigor in such cases as Dolan v. City of Tigard ${ }^{286}$ Lucas v. South Carolina Coastal Commission, ${ }^{287}$ and Nollan v. California Coastal Commission. ${ }^{288}$ The Supreme Court has also abandoned the New Deal Court's use of the rational basis test for sex discrimination cases in Goesaert v. Cleary ${ }^{289}$ for skeptical scrutiny in United States $v$. Virginia, ${ }^{290}$ and it has struck down a law targeted at gay people using the rational basis test in Romer v. Evans. ${ }^{291}$ It also struck down an ordinance that burdened the

\footnotetext{
282372 U.S. 726, 730 (1963).

283381 U.S. 479 (1965).

284410 U.S. 113 (1973).

285539 U.S. 558 (2003).

286512 U.S. 374 (1994).

287505 U.S. 1003 (1992).

288483 U.S. 825 (1987).

289335 U.S. 464 (1948).

290518 U.S. 515 (1996).

291517 U.S. 620 (1996).
} 
mentally retarded using the rational basis test in City of Cleburne v. Cleburne Living Center, Inc. ${ }^{292}$ The Court has also held that alienage and illegitimacy are suspect classes. ${ }^{293}$

In short, the Supreme Court's current caselaw interpreting the Fourteenth Amendment is a mess. The Court has made exceptions to New Deal rational basis scrutiny in discrimination cases involving sex, sexual orientation, mental retardation, alienage, and illegitimacy while it has also abandoned the rational basis test with respect to abortion laws, laws governing contraception, laws banning sodomy, and the incorporated federal Bill of Rights. Recent Takings cases reviewing zoning regulations seem clearly contrary to the post-1937 New Deal understanding. The Supreme Court needs to abandon the tiers of scrutiny and get back to the original meaning of the Fourteenth Amendment. The Court needs to realize that the Fourteenth Amendment bans class legislation, the granting of exclusive privileges, and grants of government monopoly power.

In a recent concurring opinion, Judge Janice Rogers Brown of the United States Court of Appeals for the D.C. Circuit described current protections economic liberty since the New Deal in frank terms:

America's cowboy capitalism was long ago disarmed by a democratic process increasingly dominated by powerful groups with economic interests antithetical to competitors and consumers. And the courts, from which the victims of burdensome regulation sought protection, have been negotiating the terms of surrender since the 1930 s. $^{294}$

Judicial abdication over the last half century is troubling in light of the overwhelming evidence summarized in this paper-from English and colonial history, from the debates on the federal

\footnotetext{
292473 U.S. 432 (1985).

${ }^{293}$ Plyler v. Doe, 457 U.S. 202 (1982) (alienage); Weber v. Aetna Casualty \& Surety Co., 406 U.S. 164 (1972) (illegitimacy); Gomez v. Perez, 409 U.S. 535 (1973)_(illegitimacy); Trimble v. Gordon, 430 U.S. 762 (1977) (illegitimacy).

${ }^{294}$ Hettinga v. United States, No. 11-6065 (D.C. Cir. 2012), available at http://www.cadc.uscourts.gov/internet/opinions.nsf/70A27D44D7C03503852579DF004EF65F/\$file/11-50651368692.pdf.
} 
constitution and its ratification, and from the legislative history on the Fourteenth Amendmentthat people have a right to be free from monopolies and grants of special privilege.

The Court's approach to economic liberty cases is at war with the original meaning of the Constitution and the Fourteenth Amendment. The Framers of the Constitution understood the shortcomings of the democratic process, and they foresaw the development of factions (special interest groups) which would game the legislative process to get monopoly or oligopoly rents. ${ }^{295}$ The Constitution was written to allow the courts to protect the Republic from the worst excesses of factions. In other words, the Constitution was designed to, as Judge Brown says,

Thwart threats to the Republic: the political temptation to exploit the public appetite for other people's money — either by buying consent with broad-based entitlements or selling subsidies, licensing restrictions, tariffs, or price fixing regimes to benefit narrow special interests. ${ }^{296}$

The Founders envisioned a government that was capable of preventing grants of special privileges, and, in extreme cases, preventing the conferral of outright monopolies, just as Sir Edward Coke argued almost four centuries ago. The responsibility for striking down infringements on economic liberty falls on the courts. ${ }^{297}$ Over the last half-century, the courts have failed to meet this responsibility.

\section{E. "Private” Monopolies \& Federal Antitrust Law}

One final wrinkle remains concerning the federal government and the problem of monopolies and that is to address how it is that the monopoly problem came to be seen after 1890 as a problem that stemmed mostly from private concentrations of economic power and not from corrupt government grants of power and licenses. The answer is that there was a growing

\footnotetext{
${ }^{295}$ The Federalist No. 10, at 78, 81 (James Madison) (Clinton Rossiter, ed. 1961).

${ }^{296}$ Hettinga v. United States, No. 11-6065 (D.C. Cir. 2012), available at http://www.cadc.uscourts.gov/internet/opinions.nsf/70A27D44D7C03503852579DF004EF65F/\$file/11-50651368692.pdf.

${ }^{297}$ See Federalist No. 78 (Alexander Hamilton).
} 
concern with private monopolies — those that developed without special grants from the state—in the late nineteenth century in part because of what we would today call a problem of Crony Capitalism. With the establishment of general incorporation laws in many states, parties became able for the first time to establish separate corporate entities that were protected by limited corporate liability and which benefited from perpetual life and legal personhood. Prior to the adoption of general incorporation laws, corporations were created by an act of the legislature one corporation at a time, or in England by a charter from the King. This system of private incorporation leant itself to corruption and abuse and to the granting of special privileges or monopolies. As a result, it was replaced in the United States by general laws beginning in the early nineteenth century that allowed incorporation whenever certain pre-existing conditions were met. ${ }^{298}$

General incorporation laws, however, led to some abuses. In some cases, these laws enabled the consolidation of capital into the hands of a few players. ${ }^{299}$ As Thomas Cooley warned in 1874:

[T] he most enormous and threatening powers in our country have been created; some of the great and wealthy corporations actually [have] greater influence in the country at large and upon the legislation of the country than the States to which they owe their corporate existence. ${ }^{300}$

As a result, there was a growing fear among members of the general public after the Civil War that corporate monopolists would work to ensure that the state served their private economic interests rather than serving the general interests of the public at large. ${ }^{301}$ For example, as early as 1880, the Greenback and Anti-Monopoly parties began speaking out against the "land,

\footnotetext{
${ }^{298}$ See infra Part III.A.

${ }^{299}$ Daniel A. Crane, Antitrust Antifederalism, 96 CAL. L. REV. 1, 13 (2008).

${ }^{300} \mathrm{Id}$.

${ }^{301}$ IRVING J. SLOAN, 3 AMERICAN LANDMARK LEGISLATION 5 (1976).
} 
railroad, money, and other gigantic monopolies.”302 Even the patent system was called into question for conferring private monopolies that undermined the public well being. General Ben Butler, the presidential candidate for the Greenback and Anti-Monopoly parties criticized the sewing machine monopoly, for example, which benefited from the protection of a patent. ${ }^{303}$ The Union Labor Party (which was a coalition of the Greenback Party, the Knights of Labor, and the farmer movement) declared in 1888 that "The paramount issues to be solved in the interests of humanity are the abolition of usury, monopoly, and trusts, and we denounce the Democratic and Republican parties for creating and perpetuating these monstrous evils.”304

The railroads were one of the most despised industries. In fact, as early as the Civil War, the railroad monopoly was recognized as a problem. Thanks to land grants from the federal government to build railways in the West, the industry was a hotbed of Crony Capitalism. Even during the Civil War, the federal government had to seize some railroads for the war effort. But in addition, in 1864, the House of Representatives found it necessary to pass a bill to authorize every railroad company in the country to carry government supplies, freight, mails, troops, and passengers notwithstanding any contrary monopoly. ${ }^{305}$ The bill's not-so-hidden goal was to abolish one railroad monopoly granted by the State of New Jersey in particular. A monopoly was held by the Camden and Amboy Railroad of New Jersey, which had an exclusive right of transit through New Jersey (including transportation outside the state to New York City and Philadelphia). The State granted the monopoly charter in exchange for stock in the railroad. ${ }^{306}$ Senators who were in favor of the bill to abolish the New Jersey state monopoly included none

\footnotetext{
${ }^{302}$ Id. at 8.

${ }^{303}$ William L. Letwin, Congress and the Sherman Antitrust Act, 23 U. CHI. L. REV. 234 (1956) (citing Butler, Speech of Aug. 30, 1884, appended to his pamphlet, Address to His Constituents, Aug. 12, 1884)).

${ }^{304}$ Id.

305 Great Debates in American History: ECONOMIC \& SoCiAl Questions 202 (Marion Mills Miller, ed.). ${ }^{306}$ Id.
} 
other than Charles Sumner, the radical Republican who decried monopolies and grants of special privilege in his support the Civil Rights Act of 1866 and the Fourteenth Amendment. ${ }^{307}$

In the 1865 Senate debates on the bill, Senator Sumner discusses the English history and the historic ban on monopolies while explaining his support of the federal override of the New Jersey state monopoly. ${ }^{308}$ Senator Sumner also quotes approvingly Daniel Webster's argument against the monopoly granted by the State of New York in Gibbons v. Ogden as support for the constitutionality of Congress using the Commerce Clause to override a state granted monopoly. He said: “"Now I think it very reasonable to say that the Constitution never intended to leave with the States the power of granting monopolies either of trade or of navigation; and therefore, that as to this, the commercial power is exclusively with Congress." and later "I insist that the nature of the case and of the power did imperatively require that such important authority as that of granting monopolies of trade and navigation should not be considered as still retained by the states." ${ }^{309}$ Sumner even likened the New Jersey monopoly to Apollyon in Pilgrim's Progress, ${ }^{310}$ with New Jersey as the Valley of Humiliation "through which all travelers north and south must pass, and the monopoly, like Apollyon, claims them all as 'subjects,' saying 'for all that country is mine, and I am the principle and god of it.,”311

Sumner describes the monopoly not only as hostile "to the Union," but, importantly, "as hostile to the spirit of the age, which is everywhere overturning the barriers of commerce.»312 He feared, using graphic terms, that if New Jersey was not checked in its grant of monopoly, other states would soon follow:

${ }^{307} I d$.

${ }^{308}$ Cong. Globe, 38th Cong., 2st Sess., 792 (1865) (Statement of Senator Charles Sumner).

${ }^{309}$ Id. (quoting Gibbons v. Ogden, 22 U.S. 1, 10, 14 (1824)).

${ }^{310}$ Pilgrim's Progress is a 1678 Christian allegory by John Bunyan. Apollyon is a demon that attacks Christian, the protagonist, as Christian attempts to cross the Valley of Humiliation. After a vicious half-day battle, Christian wounds Apollyon and Apollyon finally flies away.

${ }^{311}$ Id. at 792-93.

${ }^{312} I d$. at 793. 
The taste of revenue is to a Government like the taste of blood to a wild beast, quickening and maddening the energies, so that it becomes too deaf to all suggestions of injustice; and the difficulties must increase where this taxation is enforced by a far-reaching monopoly. The State, once tasting this blood, sees only an easy way of obtaining the means it desires; and other States will yield to the same temptation. ... . A profitable Usurpation, like that of New Jersey, would be a tempting example to other states ... Let this Usurpation be sanctioned by Congress, and you hand over the domestic commerce of the Union to a succession of local impost taxes ... Each State will play the part of Don Quixote, and the Union will be Sancho Panza, compelled to receive on his bare back the laches which were the penance of his master. ${ }^{313}$

Senator Sumner continued by further tying his opposition to the railroad monopoly to his hatred of the institution of slavery — which, as discussed previously in this article, he also argued was a government granted monopoly over the labor of African Americans:

The present pretension of New Jersey belongs to the same school with that abhorred and blood-bespattered pretension of South Carolina .... The monopoly which was founded on the hideous pretension of property in man obtained a responsive sympathy in that other monopoly which was founded on the greed of unjust taxation, and both were naturally upheld in the name of State rights. Both must be overthrown in the name of the Union. South Carolina must cease to be a slave State, and so must New Jersey. All hail to the genius of universal emancipation! All hail to the Union, triumphant over the rebellion, triumphant also over a usurpation which menaces the unity of the Republic! ${ }^{314}$

Despite Sumner's colorful arguments, and despite other efforts by advocates of the bill, the

measure was not brought to a vote in the Senate because of a lack of the votes to pass it. ${ }^{315}$ Opposition to railroad monopolies did not end with the federal opposition to the New Jersey railroad monopoly. As it turned out, this debate in 1864 foreshadowed public hostility toward the railroads in the coming years.

By the 1870s, the Grange Movement was formed as a group of farmers, who made opposition to monopolies their central issue to rally against and whose motto was in part the

\footnotetext{
${ }^{313}$ Id. at 793 .

${ }^{314} \mathrm{Id}$.

${ }^{315}$ Great Debates in American History: Economic \& Social Questions 226 (Marion Mills Miller, ed.)
} 
phrase "Down with Monopolies." ${ }^{316}$ The Grangers, as they were called, were mostly opposed to the railroad industry, which had driven up the price of transportation for grain. While the railroad companies were private companies and had not necessarily received exclusive privileges to operated railways, they did receive substantial benefits from the government which helped them establish monopoly economic power. Indeed, railroad companies received "tremendous" government subsidies, including both state and federal land grants, vast eminent domain powers, special tax treatment, and government bonds. ${ }^{317}$ These special benefits or privileges were well known both by Congress and by some members of the general public in the late nineteenth century. Railroads may well be natural monopolies, but the railroads in the United States had also had a lot of government help in securing the very land on which to lay their tracks. There was undoubtedly an element of Crony Capitalism at work in the building of the American railroads.

In the early debates regarding regulation of the railroad industry, several newspaper articles were recited to the House Committee on Commerce regarding the railroad industry:

Sooner or later the people will understand their rights and will maintain them, if this is their government and not one of the railroad fools and rings. - New York Journal of Commerce

... [The railroad companies] have been hedged in and protected on every side by statutes in their interests, while the people, who have nourished them until they have grown to the state of giants, and in many cases the insolence and despotism of tyrants, are left almost wholly at their mercy. It is surely time that the people began to look after their own interests. - Rochester Morning Gerald, December 21, 1881

\footnotetext{
${ }^{316}$ William L. Letwin, Congress and the Sherman Antitrust Act, 23 U. CHI. L. REV. 232-33 (1956).

${ }^{317}$ Danaya C. Wright, Pipes, Wires, And Bicycles: Rails-To-Trails, Utility Licenses, And The Shifting Scope Of Railroad Easements From The Nineteenth To The Twenty-First Centuries, 27 ECOLOGY L.Q. 351, 265 (2000)
} 
. . . No people in the world have welcomed the railroad era so joyfully as Americans; no other people have done so much, by land-grants and corporate aid, to build railroads. ... - Buffalo Express. ${ }^{318}$

Special treatment for railroads was justified on the grounds that railroads provided a public benefit by enabling people and goods to be transported across the country. This was surely true. As for the railroad companies' eminent domain powers, the takings of land on which to lay tracks were consistently upheld during the antebellum era because the land would be used for the public purpose of providing transportation, despite the fact that the direct benefits went to the private railroad companies. ${ }^{319}$ Although the railroads' vast economic power can be credited in part to special benefits given to the companies by governments, the solution for the Grange Movement was regulation and more government power and not the free market. ${ }^{320}$ The public came to think that the railroad industry in Europe was highly regulated from the early stages of its development and that it did not suffer from the same rate-abuse problems as did the railroad system in the United States. As a result, the Interstate Commerce Act was passed in 1887, primarily in order to regulate railroad rates.

However, the Grangers, along with many others during this period in American history, did not only oppose the railroads. They also opposed the big trusts, such as the Standard Oil and U.S. Steel trusts. There was a fear that these trusts threatened liberty because they would corrupt politicians by seeking special benefits and government monopoly privileges much as Andrew Jackson had feared with the Bank of the United States. The trusts did indeed benefit enormously from the very high protective tariffs which late nineteenth century politicians enacted into law

\footnotetext{
${ }^{318}$ Arguments and statements before the Comm. on Commerce in relation to certain bills referred to that committee proposing congressional regulation of interstate commerce, 47 H.R.1655, page 32 (1882) (statement of Francis B. Thurber, National Board of Trade).

${ }^{319}$ James W. Ely, Jr., Can The "Despotic Power" Be Tamed?: Reconsidering the Public Use Limitation on Eminent Domain, PROB. \& PRop. 31 (Nov./Dec. 2003).

${ }^{320}$ William L. Letwin, Congress and the Sherman Antitrust Act, 23 U. CHI. L. REV. 233 (1956).
} 
and which protected the trusts' industries from foreign competition. ${ }^{321}$ One of the things the trusts sought and got from politicians during this era was a very high tariff which directly benfitted American manufacturers at the expense of consumers. The trusts were also accused of both driving out competitors and driving up prices-thus hurting other businesses and consumers. The Sherman Antitrust Act, passed in 1890, was largely aimed at prohibiting these kinds of privately-established restraints on trade, as well as regulating the various railroad cartels.

According to Judge Robert H. Bork in his landmark book critiquing the state of federal antitrust law in the 1970s, The Antitrust Paradox, the 1890 Sherman Act's primary aim was the promotion of consumer welfare. ${ }^{322}$ Similarly, the original 1914 Clayton Antitrust Act and the 1914 Federal Trade Commission Act were both passed, according to Judge Bork, to reinforce the consumer welfare protections of the Sherman Act. ${ }^{323}$ The concern in the Progressive Era with protecting consumer welfare called for prohibitions on predatory business tactics and on horizontal mergers aimed at creating monopolies and cartels. Wide discretion was left to the courts to develop specific rules. ${ }^{324}$ Another stated purpose of the 1890 bill's sponsor, Senator John Sherman, was to codify at the federal level the common law rule, which existed in many states, outlawing private contracts that operated as restraints on trade. ${ }^{325}$ However, as Judge Bork points out, the common law doctrine on restraints of trade and monopolies had been quite “diverse” and “contradictory” and did not consistently promote competition. ${ }^{326}$ For example, Senator Sherman relied on cases that suggested that the common law prohibited Standard Oil's

\footnotetext{
321 IRVING J. SLOAN, 3 AMERICAN LANDMARK LEGISLATION 7 (1976).

${ }^{322}$ Robert H. Bork, The ANTITRUSt PARAdOX: A POLICY AT WAR WITH ITSElF 61 (1993); see also Robert H. Bork, Legislative Intent and the Policy of the Sherman Act, 9 J. LAW \& ECON. 7, 7 (1966).

${ }^{323}$ RoBert H. BORK, The ANTITRUST PARAdOX: A POLICY AT WAR WiTH ITSELF 63 (1993)

${ }^{324}$ Id. at 20.

${ }^{325}$ IRVING J. SLOAN, 3 AMERICAN LANDMARK LEGISLATION 12 (1976).

${ }^{326}$ RoBert H. Bork, The ANTITRUST PARAdOX: A POLICY AT WAR WITH ITSELF 20 (1993)
} 
railroad rebates, cartel agreements, and horizontal mergers aimed at creation of monopoly while he ignored other cases that might have suggested a contrary conclusion. ${ }^{327}$ That said, Senator Sherman and other supporters of the Sherman Antitrust Act of 1890 were quite clear about their version of the common law. Judge Bork describes that version as an "an artificial construct, made up for the occasion out of a careful selection of a few recent decisions from different jurisdictions, plus a liberal admixture of the senators’ own policy prescriptions.”328

The Sherman Antitrust Act of 1890 was inspired, at least in small part, by the Statute of Monopolies. For example, both the Statute of Monopolies and the Sherman Act gave common law courts the power to hear cases regarding alleged monopolies and provided for the same remedies: treble damages and costs to the aggrieved parties. ${ }^{329}$ In addition, while arguing for passage of the law, Senator Sherman said that the trusts "smacked of tyranny 'of a kingly prerogative,' and that a nation that 'would not submit to an emperor ... should not submit to an autocrat of trade.”,330 Recognizing, at least in part, that the government itself might have had something to do with the trusts' monopoly power, Sherman said that 'if the combination is aided by our tariff laws they should be promptly chained, and, if necessary, equal competition with all the world should be invited in the monopolized article.”331 It is doubtful that Senator Sherman was sincere regarding tariff policy, however. Shortly after the Sherman Act was passed, he supported the highly protectionist McKinley Tariff in 1890, which raised the average duty on imports to nearly fifty percent!

\footnotetext{
${ }^{327} \mathrm{Id}$

${ }^{328} I d$.

${ }^{329}$ Jay Dratler, Does Lord Darcy Yet Live? The Case Against Software and Business-Method Patents, 43 SANTA Clara L. ReV. 823, 825 (2003).

${ }^{330}$ IRVING J. SLOAN, 3 AMERICAN LANDMARK LEgISLATION 12 (1976) (citing 21 CoNG. REC. 2,457 (1890)) (emphasis added).

33121 CONG. REC. 2,457 (1890).
} 
The Sherman Antitrust Act did break with the traditional English and American concern about monopolies in one critical regard. By the Sherman Act's plain language, it applies to all monopolies, regardless of their source: "[E]very contract, combination in the form of trust or otherwise, or conspiracy, in restraint of trade or commerce among the several States, or with foreign nations, is declared to be illegal.”332 Nonetheless, notwithstanding a few rare cases involving governments outside the United States, ${ }^{333}$ antitrust policy in the United States has been primarily aimed at prohibiting only private monopolies, which is ironic to say the least since the most effective monopolies are undoubtedly those that are backed up with government power. In addition, today under the Parker doctrine, state-sanctioned monopolies are immune from scrutiny under the Sherman Antitrust Act in recognition of state sovereignty and the importance of federalism. ${ }^{334}$ The Parker doctrine has been rightly critiqued as a "complete inversion of the proper approach." 335 As Richard Epstein argues, "State-sponsored cartels in the aftermath of the New Deal legitimation are more permanent and more dangerous than privately operated ones, but they are given complete immunity from the antitrust act. This is not the way we want the system to operate." ${ }^{336}$

Also, whereas the common law historically disfavored contracts that were restraints on trade, such contracts were unconnected to the central concern regarding government-created monopolies. For example, in Rogers v. Parrey, which was decided in 1613, a carpenter sued another carpenter for violation of an agreement to cease to practice carpentry for a period of

\footnotetext{
332 Sherman Antitrust Act, § 2 (1890).

333 See, e.g., Continental Ore Co. v. Union Carbide \& Carbon Corp., 370 U.S. 690 (1962); United States v. Sisal Sales Corp., 274 U.S. 268 (1927).

${ }^{334}$ Parker v. Brown, 317 U.S. 341 (1943).

${ }^{335}$ Richard Epstein, Symposium, The Proper Goals of Antitrust: When Public and Private Interests Collide, 9 LOY. CONSUMER L. REV. 112, 125 (1997).

${ }^{336}$ Id.; see also MiCHAEL S. GREVE, THE UPSIDE-DOwn CONSTITUTION (2012) (showing how New Deal constitutionalism led to government support for cartels at both the federal and state level).
} 
twenty-one years in exchange for payment. ${ }^{337}$ Sir Edward Coke held that although absolute restraints on trade were invalid under the common law, since this was a restraint for a certain time and place for valuable consideration, it was a valid agreement. ${ }^{338}$ Nowhere in the case does Coke mention Darcy v. Allen, which was decided just ten years prior in 1603 . Further, as discussed previously, prohibiting the abuse of royal monopolies was a priority for Coke at the time since King James I was a great abuser of the royal prerogative in this area. The fact that Coke was willing to weaken the common law rule as it relates to consensual agreements among private parties that restrained trade while seeking to strengthen the rule prohibiting royal monopolies also suggests thqt the danger posed by monopolies in Coke's view was primarily with government grants of monopoly power. Thus, besides the fact that the common law prohibitions on voluntary restraints on trade and monopolies both reflect the common law interest in efficiency, the two rules otherwise do not appear to be linked.

Corporations are, however, unlike wholly private actors in one crucial way: corporations derive their very existence from the state. Further, although there are general corporate laws in place today (such that anyone may establish a corporation), corporations benefit from legal rights that individuals do not, including limited liability and perpetual life. This fact has not gone unnoticed for supporters of antitrust policy in the United States. As one leftist economist, Henry Carter Adams, argued in 1894:

At the bottom of every monopoly may be traced the insidious influence of the peculiar privileges which the law grants to corporations.... [C]orporations assert for themselves rights conferred on individuals by the law of private property, and apply to themselves a social philosophy true only of a society composed of individuals. ${ }^{339}$

${ }^{337}$ Rogers v. Parrey, 80 E.R. 1012 (1613).

${ }^{338}$ Id. at 1013.

${ }^{339}$ Daniel A. Crane, Lochnerian Antitrust, 1 J. L. \& LiBERTY 506, 511 (2005).(quoting Henry Carter Adams, Publicity and Corporate Abuses, in 1 Publications of THE Mich. Pol. SCi. Ass'N 109, 116 (1894)). 
In attempting to reconcile the Supreme Court's upholding of the constitutionality of the Sherman Antitrust Act in 1904 in Northern Securities ${ }^{340}$ with its decision in Lochner in 1905, Daniel Crane writes that the "conception of liberty as freedom from government coercion is hard to reconcile with the antitrust project until one sees that the evil that antitrust addresses is caused by a governmental dislocation of the market." ${ }^{341}$

But the argument that private monopolies were possible due to the development of general corporate laws is not persuasive. General incorporation law, enabling virtually all people to form corporations, was an option available to all and thus was not a special privilege given only to a few monopolists. Moreover, the general incorporation laws can be defended on the ground that such laws merely lower the transaction costs of forming what were previously complex partnerships by substituting partnership agreements with a standard corporate form. It is doubtful that merely lowering the transaction costs for the creation of certain types of business associations, which largely could still exist absent general incorporation laws, led to the development of trusts.

While the Privileges or Immunities clause is a near dead letter in the U.S. Constitution, ${ }^{342}$ and the Lochner era ended with the New Deal, the states are still free to protect liberty in their own respective state constitutions to a greater degree than the federal government does. Indeed, Louisiana amended its constitution after the Slaughter-House Cases to prohibit monopolies, and Louisiana did not act alone since other states have adopted anti-monopoly provisions as well. ${ }^{343}$ Part III will explore the several state constitutional provisions that prohibit monopolies and the

\footnotetext{
${ }^{340}$ N. Sec. Co. v. United States, 193 U.S. 197 (1904).

${ }^{341}$ Daniel A. Crane, Lochnerian Antitrust, 1 J. L. \& LIBERTY 506, 512 (2005).

${ }^{342}$ But see McDonald v. Chicago, 130 S. Ct. 3020 (2010) (Thomas, J., concurring) (discussing the history and purpose of the Privileges or Immunities Clause and arguing that the Second Amendment should be incorporated through the Privileges or Immunities Clause, not the Due Process Clause).

${ }^{343}$ See, e.g., MD. CONST. OF 1867, Declaration of Rights, art. 41.
} 
early state cases interpreting and applying these provisions. Part III will also review the applications and limitations of these provisions in modern state constitutional law and will discuss why many states have not adopted such provisions in their constitutions.

\section{Monopolies AND State Constitutional LAW}

While the federal Constitution does not have an explicit antimonopoly provision, such provisions are included in nineteen state constitutions today. ${ }^{344}$ Only two states had antimonopoly provisions at the Founding. ${ }^{345}$ By 1868, four states included antimonopoly provisions and several others included prohibitions on the granting of exclusive privileges or immunities. $^{346}$ Provisions were also added in state constitutions after 1868 including in the Progressive Era. ${ }^{347}$ Some of the more recently added provisions appear to be primarily or even exclusively concerned with prohibiting private monopolies, ${ }^{348}$ but many states use similar language as was used in the provisions from the time of the Founding and of 1868 when a ban on monopoly meant only a ban on a government grant of privilege. ${ }^{349}$

\footnotetext{
${ }^{344}$ See Ala. ConsT. art. IV, § 103; ARK. Const. art. 2, § 19; GA. CONST. art. 3, § 6, ๆ V; MD. ConsT., Declaration of Rights, art. 41; MinN. Const. art. 13, § 6; N.J. Const. art. 4, § 7, ๆ 9, N.M. Const. art. 4, § 38; N.C. Const. art. I, § 34; OKLA. CONST. art. 5, § 44; S.D. ConsT. art. 17, § 20; TENN. CONST. art. 1, § 22; TEX. ConsT. art. 1, § 26; UTAH CONST. art. 12, § 20; WASH. ConST. art. 12, § 22; Wyo. CONST. art. 1, § 30; ConN. Const. OF 1818, art. I, § 1; MASS. CONST. Of 1780, DeCL. OF RIGHTS, art. VI; ARIZ. CONST. OF 1910, art. XIV, § 15; KY CONST. OF 1891, § 198; N.H. CONST., art. 83.

${ }^{345}$ See infra Part III.B.1.

${ }^{346}$ Steven G. Calabresi \& Sarah E. Agudo, Individual Rights Under State Constitutions when the Fourteenth Amendment Was Ratified in 1868: What Rights Are Deeply Rooted in American History \& Tradition?, 87 TEX. L. REV. 7, 73, tbl. 76 (2008) (citing MD. CoNST. OF 1867, Declaration of Rights, art. 41; TN. CoNST. OF 1834, art. 1, § 22; NC CONST. Of 1868, art. 1, § 31; NJ Const. OF 1844, art. 4, § 7.11; TX. Const. OF 1868, art. 1, § 18). See also infra Part III.B.2.

${ }^{347}$ See infra Part III.B.3.

${ }^{348}$ See, e.g., WASH. CONST., art 12, § 22 ("Monopolies and trusts shall never be allowed in this state, and no incorporated company, copartnership, or association of persons in this state shall directly or indirectly combine or make any contract with any other incorporated company, foreign or domestic, through their stockholders, or the trustees or assignees of such stockholders, or with any copartnership or association of persons, or in any manner whatever for the purpose of fixing the price or limiting the production or regulating the transportation of any product or commodity. The legislature shall pass laws for the enforcement of this section by adequate penalties, and in case of incorporated companies, if necessary for that purpose, may declare a forfeiture of their franchises.”)

${ }^{349}$ WYO. CONST., art. 1, § 30 (adopted in 1889 and providing that "Perpetuities and monopolies are contrary to the genius of a free state, and shall not be allowed. Corporations being creatures of the state, endowed for the public good with a portion of its sovereign powers, must be subject to its control.”).
} 
Some of the state constitutional provisions banning monopoly were broadly worded to prohibit any unequal grant of privileges or immunities to certain citizens or classes of citizens. ${ }^{350}$ Others, however, are more narrowly worded and prohibit only the grant of monopolies or of exclusive privileges. We will focus here on the narrower State provisions which expressly banned monopolies and exclusive privileges.

This section discusses the roots of the state constitutional tradition on bans of monopolies, which is based in part on the Jacksonian aversion to monopolies and grants of special privilege discussed above. We will then discuss the adoption of state constitutional provisions in three distinct periods: 1) at the Founding, 2) during the nineteenth century, and 3) during the progressive era. Third, we will discuss the application of these state constitutional provisions in state courts during the twentieth century and the influence of federal constitutional law and treatment of economic liberty cases on state court decisions. Finally, this section concludes by discussing potential reasons as to why not all states have included provisions prohibiting monopolies and grants of special privilege today.

\section{A. A Tradition Rooted in Jacksonian Democracy \& Changes in Corporate Law}

State constitutional prohibitions on monopolies and the granting of exclusive privileges are closely tied to the states' traditional prohibition of partial and special laws which developed during the antebellum era, as discussed previously in Part I.B.3 above. ${ }^{351}$ During this period, state courts routinely struck down laws that granted special benefits or imposed special burdens on persons or classes of people. ${ }^{352}$ Prohibitions on partial or special laws in some form were

\footnotetext{
${ }^{350}$ Melissa L. Saunders, Equal Protection, Class Legislation, and Colorblindness, 96 MiCH. L. REV. 245, 258 (2003).

${ }^{351}$ Melissa L. Saunders, Equal Protection, Class Legislation, and Colorblindness, 96 Mich. L. Rev. 245, 25152 (2003).

${ }^{352}$ Id. at 252.
} 
included in nearly every state constitution during the first half of the nineteenth century. This state constitutional tradition was closely tied to the Jacksonian conception of democracy.

A central tenet of Jacksonian democracy was that the state should not establish monopolies or grant special privileges to particular individuals or classes of people. ${ }^{353}$ For this reason, President Jackson opposed the second Bank of the United States in part because it had monopoly powers. Jackson argued that "the 'great evils to our country and institutions might flow from such a concentration of power in the hands of a few men irresponsible to the people.”,354 One of Jackson’s journalists wrote that “All Bank charters, all laws conferring special privileges, with all acts of incorporations [sic], for purposes of private gain, are monopolies, inasmuch as they are calculated to enhance the power of wealth, produce inequalities among the people, and subvert liberty." 355 Another wrote that: "to have the land scattered over with incorporated companies, is to have a class of privileged, if not titled, nobility."356

However, President Jackson's opposition to corporations in the 1820s and 1830s should not be viewed by modern readers as an opposition to corporations as they exist today. As a matter of corporate law history, it is important to note that it was not until the late nineteenth century that most states passed general incorporation laws. Before that time, people had to obtain a special grant from the legislature, or in England from the King, in order to establish a

\footnotetext{
${ }^{353}$ Id. at 256-57 (citing HowARD GILLMAN, THE CONSTITUTION BESIEGED: THE RISE AND DEMISE OF LOCHNER ERA Police POWERS JURISPRUDENCE 33-45(1993); WILliAM LEGGETT, DEMOCRATICK EDITORIALS: ESSAYS IN JACKSONIAN POLITICAL ECONOMY 19-20 (Lawrence H. White ed., 1984); MARVIN MEYERS, THE JACKSONIAN Persuasion: Politics AND Belief 185-233 (1960); Robert Remini, The Age OF JACKSON at xvi-xix (1972); ROBERT REMINI, ANDREW JACKSON AND THE COURSE OF AMERICAN FREEDOM: 1822-1832, at 34 (1981); ARTHUR M. SCHLESINGER, JR., THE AGE OF JACKSON 306-21 (1945); GLYNDON G. VAN DEUSEN, THE JACKSONIAN ERA 95, 103 (1959); SOCIAL THEORIES OF JACKSONIAN DEMOCRACY: REPRESENTATIVE WRITINGS OF THE PERIOD 18251850, at 75-76 (Joseph L. Blau ed., 1954); Michael Les Benedict, Laissez-Faire and Liberty: A Re-Evaluation of the Meaning and Origins of Laissez-Faire Constitutionalism, 3 LAW \& HIST. REv. 293, 318-21 (1985)).

${ }^{354}$ IRVING J. SLOAN, 3 AMERICAN LANDMARK LEGISLATION 2 (1976).

${ }^{355} \mathrm{Id}$. at 4.

${ }^{356} \mathrm{Id}$.
} 
corporation. ${ }^{357}$ The thirteen colonial charters from which the thirteen original States grew were all in essence just special licenses from various English Kings.

Special grants of corporate status from a legislature were referred to as statutory charters and were not merely limited to being licenses for a corporation to exist. Rather, statutory corporate charters were more like constitutions that established a corporation's internal structure. $^{358}$ These grants by definition gave special privileges to the incorporators since not everyone was able to obtain a charter from the legislature. Common benefits of corporate status included limited liability from claims against the corporation, immunity from debts, and the ability to sue and be sued. ${ }^{359}$ Early on, corporate charters were primarily issued to what may today be considered public utilities, including businesses involved in transportation, water supply, insurance, and banks. ${ }^{360}$ As one New England politician and lawyer, Theodore Sedgwick, pointed out in 1835, “corporations can only obtain existence . . by a special grant from the legislature. Charters of corporations are therefore grants of privilege, to be exclusively enjoyed by the corporators .... Every grant of exclusive privilege, strictly speaking, creates a monopoly.”361

James Willard Hurst points out in his book on the history of corporations in the United States that the Jacksonian attack on corporations was much less an attack on the corporate status of such entities than it was a complaint about the special privileges or immunities some businesses enjoyed that were denied to other similar businesses and individuals. ${ }^{362}$ Special privileges or immunities were commonplace for legislatively chartered corporations in the early

\footnotetext{
${ }^{357}$ IRVING J. SLOAN, 3 AMERICAN LANDMARK LEGISLATION 3 (1976).

358 JAMES WILLARD HURST, THE LEGITIMACY OF THE BUSINESS CORPORATION IN THE LAW OF THE UNITED STATES 1780-1970, at 16.

${ }^{359} \mathrm{Id}$. at 19.

${ }^{360} \mathrm{Id}$. at 17.

${ }^{361}$ IRVING J. SLOAN, 3 AMERICAN LANDMARK LEGISLATION 13 (1976).

362 JAMES WiLLARD HURST, THE LEGITIMACY OF THE BUSINESS CORPORATION IN THE LAW OF THE UNITED STATES 1780-1970, at 33 (1970).
} 
nineteenth century. These privileges or immunities included the ability to issue bank notes (which was generally limited to incorporated banks) and to exercise the power of eminent domain-a power which was given to some railroads. ${ }^{363}$ It may help to consider a specific example: the Society for Establishing Useful Manufactures, which was a New Jersey corporation that was exempt from having to pay taxes on much of its property, which was given authority to conduct lotteries, which could exercise power of eminent domain, and which enjoyed a subsidy that exempted its workmen from all taxes and military service. ${ }^{364}$

It was not until the development of general incorporation laws, beginning in the midnineteenth century, that corporate law in the United States ceased to be a field of special grants of privilege to a few individuals. In fact, the development of general incorporation laws was itself closely tied with the Jacksonian abhorrence for monopolies and for what we would today call “Crony Capitalism”. ${ }^{365}$ General incorporation acts within the states were developed to correspond to the various state constitutional bans on special privileges, including antimonopoly provisions and bans on exclusive privileges. In fact, in his book on the American business corporation, Ronald Seavoy describes general incorporation statutes for business as a “major aspect of the social and political forces that democratized American society” during what Seavoy calls the “Age of Jackson, 1825-1855.”366 For example, when the 1846 New York Constitution was adopted, it provided that corporations were to be formed under general laws of incorporation

\footnotetext{
${ }^{363}$ Id. at 20.

364 IRVING J. SLOAN, 3 AMERICAN LANDMARK LEGISLATION 3 (1976).

${ }^{365}$ HERBERT HOVENKAMP, ENTERPRISE AND AMERICAN LAW, 1836-1937, at 2 (1991) (“[Jackson’s] regime . . . stood for growth, unobstructed by “artificial” constraints . . . . The modern business corporation had its origin in the general corporation acts, one of the most important legal accomplishments of a regime bent on democratizing and deregulating American business.”).

${ }^{366}$ RonAlD SEAVOY, THE ORIGINS OF THE AMERICAN BuSINESS CORPORATION, 1784-1855, at 182 (1982).
} 
and that special charters were banned except in certain limited instances. ${ }^{367}$

As historian

Gordon Wood describes these laws, they

“Opened up the legal privileges to all who desired them” ... [and] "Within a few years most of them became very different from their monarchical predecessors: they were no longer exclusive monopolies and they were no longer public. They became private property and what Samuel Blodget in 1806 called 'rivals for the common weal.,",368

General incorporation laws were critical to preventing the states from granting special economic advantages to one group over another, and they democratized all the benefits of having corporations by allowing anyone to set up a corporation if they followed the right procedures for doing so. Limited liability for corporations might also be considered part of the democratization of corporate law as well, because it lessened the risks associated with investment, thus making investments a possibility for people with fewer assets. General incorporation laws thus were answers to the "Jacksonian outcry against corporations . . . [that] all should have reasonably equal access to the benefits of incorporation.”369 As Ronald Seavoy explains in The Origins of the American Business Corporation, general incorporation laws were at the core of laissez-faire and of Jacksonian thought. The goal was to remove the government from involvement with the formation of corporations by making the benefits of forming a corporation available to all. ${ }^{370}$

As constitutional lawyer Timothy Sandefur describes this change in incorporation law during the nineteenth century, "the corporation was shorn of its special monopolistic status and became instead what contemporaries called 'self-created societies' whose existence was merely

${ }^{367}$ Id. at 120 . The New York Constitution provided that "Corporations may be formed under general laws; but shall not be created by special act, except for municipal purposes, and in cases where, in the judgment of the legislature, the objects of the corporation cannot be attained under general laws. All general laws and special acts passed pursuant to this section may be altered from time to time, or repealed.” N.Y. CONST. OF 1846, art. VIII, sec. 1.

368 Timothy SANDEfur, The Right to EARN A LiVING 27-28 (2010) (quoting Gordon S. WoOd, THE RADICALISM OF THE AMERICAN REVOLUTION 321 (1992)).

${ }^{369}$ Id.; see also RONALD SEAVOY, THE ORIGINS OF THE AMERICAN BUSINESS CORPORATION, 1784-1855, at 181 (1982)

${ }^{370}$ RonAlD SEAVOy, THE ORIGINS OF THE AMERICAN BuSINESS CORPORATION, 1784-1855, at 181 (1982). 
certified or recognized by the state’s ministerial act.”371 The privatization, so to speak, of corporations meant that the new corporations were not defined by government decree, but rather by the contractual obligations and rights that were established by investors or by the directors of the corporation. ${ }^{372}$ Indeed, today it is incorrect to refer to corporations as "creatures of the state" because general incorporation statutes typically provide that corporations exist automatically once the necessary filings have been made. The government need not grant any special permission for a corporation to be formed. ${ }^{373}$

\section{B. The Adoption of Antimonopoly Provisions}

\section{Provisions Adopted at the Founding}

The first two states to ban monopolies in their state constitutions were Maryland and North Carolina. Both state constitutions included essentially the same language. Maryland's Bill of Rights provided (and, in fact, still does to this day), “That monopolies are odious, contrary to the spirit of a free government, and the principles of commerce; and ought not to be suffered.”374 Similarly, North Carolina’s Constitution read “That perpetuities and monopolies are contrary to the genius of a free State, and ought not to be allowed.”375 Like Maryland, North Carolina’s constitution also contains essentially the same language today. ${ }^{376}$

While there are not many early cases interpreting these provisions, the North Carolina Supreme Court did interpret and apply its antimonopoly provision in 1855 . The case involved whether a railroad could build a bridge over a stream although another company had an

\footnotetext{
371 TIMOTHY SANDEFUR, THE RIGHT TO EARN A LIVING 28 (2010).

${ }^{372} \mathrm{Id}$.

${ }^{373} \mathrm{Id}$.

${ }^{374}$ MD. CONST. OF 1776, art. XXXIX, reprinted in 1 THE FEDERAL AND STATE CONSTITUTIONS, COLONIAL Charters, And Other Organic Laws of the United States 817, 820 (Ben Perley Poore ed., 2d ed. Washington Gov't Printing Office 1878) [hereinafter FEDERAL AND STATE CONSTITUTIONS].

${ }^{375}$ N.C. CONST. OF 1776, art. XXIII, reprinted in 2 FEDERAL AND STATE CONSTITUTIONS, id., at 1410. CONST. OF 1868, art $1, \S 31$.

${ }^{376}$ N.C. CONST. art. $1, \S 34$ ("Perpetuities and monopolies are contrary to the genius of a free state and shall not be allowed.”).
} 
exclusive right from the state to operate a toll bridge across the same stream. ${ }^{377}$ The court ruled that the railroad could build the bridge because the state could not grant perpetuities or monopolies to private parties. In applying the North Carolina Constitution, which prohibited both exclusive privileges and monopolies, the court noted that:

"[T]he people" who were then exercising the highest act of sovereignty-that of making a government for themselves, forbade the creation of monopolies and put an end to all such as then existed.

The meaning and purpose was to forbid and abolish all hereditary and perpetual monopolies as "contrary to the genius of a free State," and to put in motion the "new State" they were then organising, as a free representative republican government, relieved from all fetters and trammels previously existing by which its action might be cramped or circumscribed, and fully authorised to do every thing necessary and proper to accomplish its mission, i.e. promote the general welfare. $^{378}$

As this passage illustrates, the provisions in both constitutions firmly reflect the traditional concerns about state-created monopolies.

In addition, eight states at the time of the Founding had Privileges and Immunities Clauses. Those states included: Connecticut, Massachusetts, North Carolina, New Hampshire, New Jersey, New York, Rhode Island, and Virginia. ${ }^{379}$ For example, Massachusetts's constitution of 1780 provided that "no subject shall be . . . deprived of his property, immunities, or privileges . . . but by the judgment of his peers, or the law of the land." 380 and "No man, nor corporation, or association of men, have any other title to obtain advantages, or particular and exclusive privileges, distinct from those of the community, than what arises from the

${ }^{377}$ McRee v. Wilmington \& R.R. Co., 47 N.C. 186, 1855 WL 1421 (1855).

${ }^{378}$ Id. at *4 (citing N.C. ConsT. OF 1776 art. 1, §§ 22, 23 \& DECLARATION OF RighTS, $\S 3$ (§ 22 stated "That no hereditary emoluments, privileges, or honors, ought to be granted or conferred in this State.” and the Declaration of Rights, § 3 provided “That no man, or set of men, are entitled to exclusive or separate emoluments or privileges from the community, but in consideration of public services.”)).

${ }^{379}$ See Steven G. Calabresi, Sarah Agudo, \& Kathryn Dore, State Bills of Rights in 1787 and 1791: What Individual Rights Are Really Deeply Rooted in American History and Tradition? (draft as of January 20, 2012, on file with authors).

${ }^{380}$ MASS. CONST. OF 1780, Pt. 1, Art. 12. 
consideration of services rendered to the public.”381 North Carolina’s constitution if 1776, which also banned monopolies, said that "No man or set of men are entitled to exclusive or separate emoluments or privileges from the community but in consideration of public services.”382 Virginia’s Constitution of 1776 stated “That no man, or set of men, are entitled to exclusive or separate emoluments or privileges from the community, but in consideration of public services; which not being descendible, neither ought the offices of magistrate, legislator or judge, to be hereditary.” ${ }^{383}$ These Clauses all would seem to ban monopolies under any plausible reading of their language.

\section{The Middle to Late Nineteenth Century}

By 1868, four states had explicit antimonopoly provisions in their constitutions. ${ }^{384}$ The new states to include antimonopoly provisions by the time of the adoption of the Fourteenth Amendment were Tennessee and Texas. ${ }^{385}$ Two states would follow shortly thereafter: Arkansas and Georgia. Several other states had prohibitions on exclusive privileges. At least four states also had prohibitions on exclusive privileges by 1868 (Connecticut, Massachusetts, Missouri, and New Jersey). Several more, including South Dakota, Colorado, and Louisiana, would follow shortly thereafter. ${ }^{386}$

\footnotetext{
${ }^{381}$ MASS. CONST. OF 1780, DECL. OF RightS, art. VI.

${ }^{382}$ NC CONST. OF 1776.

383 VA CONST. OF 1776.

${ }^{384}$ Steven G. Calabresi \& Sarah E. Agudo, Individual Rights Under State Constitutions when the Fourteenth Amendment Was Ratified in 1868: What Rights Are Deeply Rooted in American History \& Tradition?, 87 TEX. L.

${ }^{385}$ Id. at tbl. 76.

${ }^{386}$ CONN. CONST. OF 1818, art. I, § 1; MASs. CONST. OF 1780, DECL. OF RIGHTS, art. VI; Steven G. Calabresi \& Sarah E. Agudo, Individual Rights Under State Constitutions when the Fourteenth Amendment Was Ratified in 1868: What Rights Are Deeply Rooted in American History \& Tradition?, 87 TEX. L. REV. 7, 73 (2008). Note also that Mississippi's constitution included a prohibition on exclusive privileges until Mississippi adopted a new constitution in 1868. See Miss. CONST. Of 1832, art. I, § 1 ("[N]o man, or set of men, are entitled to exclusive, separate public emoluments or privileges from the community, but in consideration of public services.”)
} REV. 7, 73 (2008). 
Tennessee's Constitution provided in 1834 "That perpetuities and monopolies are contrary to the genius of free State, and shall not be allowed."387 Texas adopted an antimonopoly provision in 1868, which similarly read, "Perpetuities and monopolies are contrary to the genius of a free government, and shall never be allowed, nor shall the law of primogeniture or entailments ever be in force in this State.”388 In an early Texas case, which struck down a law granting a businessman the exclusive right to sell meat and fish within the city limits in exchange for building a town hall facility, the court determined the purpose of the antimonopoly provision to be as follows:

To place the people of the city, with respect to fresh meats and fish, at the mercy of [the businessman], or any other person, would be to allow a most dangerous monopoly, notwithstanding the prohibition in the bill of rights, which was intended to protect the people against just such monopolies, and to give them the right to have fair competition in the markets to which they must resort to purchase the necessaries of life. And this is one of the most important bulwarks thrown around the liberties of the people. Whatever tends to evade or destroy the effect of it should be denounced as void by the courts of the country. ${ }^{389}$

In the years shortly following the adoption of the Fourteenth Amendment, two more states, Arkansas and Georgia, amended their Constitutions to ban monopolies. Arkansas's Constitution of 1874, which mirrored its earlier constitutions (except the constitution of 1868), ${ }^{390}$ banned monopolies by providing, "Perpetuities and monopolies are contrary to the genius of a republic, and shall not be allowed ....”391 Relatedly, the Arkansas Constitution also provided that "The General Assembly shall not grant to any citizen nor class of citizens, privileges or immunities which, upon the same terms, shall not equally belong to all citizens.”392 In 1877, Georgia’s constitution provided that “The General Assembly of this State shall have no power to

\footnotetext{
387 TENN. CONST. OF 1834, art. 1, § 22.

388 TEX. CONST. OF 1868, art. 1, § 18.

${ }^{389}$ City of Brenham v. Becker, 1 White \& W. 714, 716 (Tex. Comm’n App. 1881).

${ }^{390}$ See N. Little Rock Transp. Co. v. City of North Little Rock, 184 S.W.2d 52, 54 (Ark. 1944) (discussing the history of the clause in the Arkansas Constitutions).

${ }^{391}$ ARK. CONST. OF 1874, art. 2, § 19.

${ }^{392}$ Id. $\S 18$.
} 
. . . make any contract, or agreement whatever, with any such corporation, which may have the effect, or be intended to have the effect, to defeat or lessen competition in their respective businesses, or to encourage monopoly; and all such contracts and agreements shall be illegal and void.”393 Both states’ constitutions contain antimonopoly provisions today. However, Georgia changed the wording of its provision, and it seems to have weakened, its language. The Georgia constitution now reads that monopolies are unlawful and void, but statutes which lessen competition may be permissible in several circumstances. ${ }^{394}$

While some states passed antimonopoly clauses, others included prohibitions on granting exclusive privileges, which arguably provides even broader protection against government favoritism than is provided by a monopoly ban. New Jersey adopted a clause prohibiting the granting of exclusive privileges in 1844. It provided that "The legislature shall not pass ... laws in any of the following enumerated cases; . . . Granting to any corporation, association or individual any exclusive privilege, immunity, or franchise whatever . . ..”395 Connecticut's Exclusive Privileges Clause provided in 1818 that "no man or set of men are entitled to exclusive public emoluments or privileges from the community.”396 Other states to have privileges or immunities provisions by 1868 included Arkansas (in 1868), ${ }^{397}$ Georgia (in 1868), ${ }^{398}$ Indiana (in 1851), ${ }^{399}$ Iowa (in 1857), ${ }^{400}$ Oregon (in 1857), ${ }^{401}$ South Carolina (in 1868), ${ }^{402}$ Tennessee (in

${ }^{393}$ GA. CONST. OF 1877 , art. 4 , § 2.

${ }^{394}$ GA. CONST., art. 3, § 6, ๆ V(c)(2) (providing exceptions for laws concerning “(A) Employers and employees; (B) Distributors and manufacturers; (C) Lessors and lessees; (D) Partnerships and partners; (E) Franchisors and franchisees; (F) Sellers and purchasers of a business or commercial enterprise; or (G) Two or more employers”).

395 N.J. CONST. OF 1844, art. 4, § 7.11.

${ }^{396}$ CONN. CONST. OF 1818, art. I, § 1.

397 “The General Assembly shall not grant to any citizen or class of citizens, privileges or immunities which, upon the same terms, shall not equally belong to all citizens.” ARK. CONST. OF 1868, Art. 1, § 18.

398 "All persons born or naturalized un the United States, and resident in this State, and no laws shall be made or enforced which shall abridge the privileges or immunities of citizens of the United States, or of this state.” GA. CONST. OF 1868, Art. 1, § 2.

399 “The General Assembly shall not grant to any citizen, or class of citizens, privileges or immunities which, upon the same terms, shall not equally belong to all citizens.” IND. ConST. OF 1851, Art. 1, § 23. 
1834), ${ }^{403}$ and Texas (in 1845). ${ }^{404}$ South Dakota (1885), ${ }^{405}$ Colorado (1876), ${ }^{406}$ and

Louisiana’s ${ }^{407}$ provisions, which were added after 1868, are similarly worded.

The text of these state privileges and immunities clauses varied greatly. For example, Georgia’s simply stated "The social status of the citizen shall never be the subject of legislation.” Arkansas’s more typical language was that: “The General Assembly shall not grant to any citizen or class of citizens, privileges or immunities which, upon the same terms, shall not equally belong to all citizens.” Likewise, Iowa’s clause provided that: “All laws of a general nature shall have a uniform operation; the General Assembly shall not grant to any citizen or class of citizens, privileges or immunities, which upon the same terms shall not equally belong to all citizens.” South Carolina's Reconstruction era constitution explicitly referred to race, saying "Distinction, on account of race or color, in any case whatever, shall be prohibited, and all classes of citizens shall enjoy, equally, all common public, legal, and political privileges.” Reference to a social contract theory of government is found in both Texas and Kentucky's privileges and immunities clauses. Kentucky’s Constitution of 1850 stated “That all freemen,

\footnotetext{
400 "All laws of a general nature shall have a uniform operation; the General Assembly shall not grant to any citizen or class of citizens, privileges or immunities, which upon the same terms shall not equally belong to all citizens.” IOWA CONST. OF 1857, Art. 1, § 6.

401 "No law shall be passed granting to any citizen orclass of citizens privileges or immunities which, upon the same terms, shall not equally belong to all citizens.” OREGON CONST. OF 1857, Art. 1, § 21.

402 "Representation shall be apportioned according to population, and no person in this State shall be disfranchised, or deprived of any of the rights or privileges now enjoyed, except by the law of the land or the judgment of his peers.” S.C. CONST. OF 1868, Art. 1, § 34.

403 "The legislature shall have no power to suspend any general law for the benefit of any particular individual, nor to pass any law for the benefit of individuals inconsistent with the general laws of the land; nor to pass any law granting to any individual or individuals rights, privileges, immunities, or exemptions other than such as may be by the same law extended to any member of the community who may be able to bring himself within the provisions of such law.” TenN. CONST. OF 1834, Art. 11, § 7.

404 "All freemen, when they form a social compact, have equal rights; and no man or set of men is entitled to exclusive separate public emoluments or privileges.” TEX. CONST. OF 1845, Art. 1, § 2.

405 "Equal privileges or immunities. No law shall be passed granting to any citizen, class of citizens or corporation, privileges or immunities which upon the same terms shall not equally belong to all citizens or corporations.” S.D. CONST. OF 1885, Art. VI, § 18.

406 "That no . . law . . . making any irrevocable grant of special privileges, franchises or immunities, shall be based by the General Assembly.” Colo. Const. OF 1876, Art. 2, § 11.

407 "The General Assembly shall not pass any local or special law ... Granting to any corporation, association, or individual any special or exclusive right, privilege, or immunity.” LA. CONST. OF 1879, art 46.
} 
when they form a social compact, are equal, and that no man or set of men are entitled to exclusive, separate public emoluments or privileges from the community, but in consideration of public services" and Texas's constitution of 1845 said that: "All freeman, when they form a social compact, have equal rights; and no man or set of men is entitled to exclusive separate public emoluments or privileges.” All these clauses were supplemented as well by bans in some form on titles of nobility and on feudalism in both the federal and in many state constitutions.

A review of the case law suggests that prohibitions on the granting by state governments of exclusive privileges functioned in much the same way as did the antimonopoly provisions. As the Supreme Court of Connecticut held in 1856 when striking down a law which granted the exclusive right use city streets to lay gas pipes to provide gas to the city:

[A]lthough we have no direct constitutional provision against a monopoly, yet the whole theory of a free government is opposed to such grants, and it does not require even the aid which may be derived from the Bill of rights, the first section of which declares "that no man or set of men, are entitled to exclusive public emoluments, or privileges from the community,” to render them void. ${ }^{408}$

Thus, for the court, the right to be free from monopolies was central to the existence of a free government, much as the North Carolina case had argued which we mentioned above. ${ }^{409}$ Even without the prohibition on exclusive privileges, any law granting a monopoly must be void. However, for the Connecticut court, the prohibition on exclusive privileges was also sufficient to render the law void as well. However, the Supreme Court of Massachusetts's 1814 explanation of the provision suggests that the prohibition on exclusive privileges is broader than a ban on monopolies:

[I]t is manifestly contrary to the first principles of civil liberty and natural justice . .. that any one citizen should enjoy privileges and advantages which are denied to all others under like circumstances; or that anyone should be subjected to losses,

\footnotetext{
${ }^{408}$ The Norwich Gaslight Co. v. The Norwich City Gas Co., 25 Conn. 19 (1856) (note that this case was cited by the butchers' counsel in the Slaughter-House Cases, 83 U.S. at 48).

${ }^{409}$ See supra Part III.B.1.
} 
damages, suits or actions, from which all others under like circumstances are exempted. ${ }^{410}$

Privileges and immunities clauses in the states have also been useful for striking down state grants of monopoly. For example, the Washington Supreme Court struck down a Seattle ordinance taxing vending machines but not in-person sales because "[t]he tendency of this kind of an income is to foster monopolies, for a monopoly exists when the manufacture and sale of any commodity is restrained to one or a certain number ... If this ordinance can be sustained, ... the constitutional guaranty [of the privileges and immunities provision] becomes a dead letter." ${ }^{411}$ Similarly, the Oregon Supreme Court held in 1904 that the State’s refusal to grant a license to operate a sailors boarding house for the purpose of maintaining only one boarding house "upon the theory that the issuance of only one license at the port of Portland would advance the shipping interests, improve the condition of seamen, and promote the welfare of the public" violated the Oregon Constitution's privileges and immunities clause. ${ }^{412}$ Importantly, the court noted that although Justice Miller ruled in the Slaughter-House Cases that states have the ability to grant exclusive rights to carry on certain businesses under the Fourteenth Amendment, this was not the case under the privileges and immunities clause of the Oregon Constitution. Despite the Slaughter-House ruling, the court decided that "under a Constitution like ours, we feel satisfied that [granting exclusive rights] cannot be done." ${ }^{413}$

Still, some states struck down similar laws during this period without reference to the protection of any economic rights, but rather because the exercise of that power was not within a city's charter. This was the case in the 1856 case, cited in Slaughter-House and discussed above, in Connecticut. Connecticut's Supreme Court of Errors court relied on Darcy v. Allen and the

\footnotetext{
${ }^{410}$ Holden v. James, 11 Mass. 396, 404 (1814).

${ }^{411}$ City of Seattle v. Dencker, 108 P. 1086 (Wash. 1910).

${ }^{412}$ White v. Holman, 74 P. 933 (Or. 1904).

${ }^{413}$ Id. at 186.
} 
Statute of Monopolies to strike down a law which granted a franchise to a corporation giving it an exclusive privilege to use streets to lay gas pipe. ${ }^{414}$ Similarly, in an 1837 New York case, the chancery court refused to enforce a city ordinance which would have prohibited a manufacturer of pressed hay from erecting a wooden frame building while allowing another manufacturer to do so. ${ }^{415}$ In a third case, in 1867 the Supreme Court of Illinois struck down a Chicago ordinance which limited the ability to slaughter animals to only one firm. ${ }^{416}$ In reference to the city’s municipal laws, the court said that such a law "impairs the rights of all other persons, and cuts them off from a share in not only a legal, but a necessary business." ${ }^{417}$ The court warned that a city’s by-laws “must be reasonable, and such as are vexatious, unequal or oppressive, or are manifestly injurious to the interest, of the corporation, are void. And of the same character are all by-laws in restraint of trade, or which necessarily tend to create a monopoly." 418

\section{The Progressive Era}

The popular fear of the so-called "Robber Barons” of the Industrial Era made people concerned with the consequences of privately created monopolies. ${ }^{419}$ As discussed in greater detail in Part I.B.2. above, with the adoption of the Sherman Antitrust Act in $1890,{ }^{420}$ and the Clayton Antitrust Act in $1914,{ }^{421}$ the Progressive-era provisions in state constitutions similarly reflect a shift away from concerns with directly state-granted monopolies to a fear of private

\footnotetext{
414 The Norwich Gaslight Co. v. The Norwich City Gas Co., 25 Conn. 19 (1856) (cited by the butchers’ counsel at Slaughter-House Cases, 83 U.S. at 48).

${ }^{415}$ The Mayor of the City of Hudson v. Thorne, 7 Paige Ch. 261 (N.Y. Ch. 1838) ("the common council cannot make a by-law which shall permit one person to carry on the dangerous business, and prohibit another, who has an equal right, from pursuing the same business”) (cited by the butchers' counsel at Slaughter-House Cases, 83 U.S. at 48).

${ }^{416}$ City of Chicago v. Rumpff, 45 Ill. 90 (1867) (cited by the butchers' counsel at Slaughter-House Cases, 83 U.S. at 48).

${ }^{417} \mathrm{Id}$.

${ }^{418} I d$. (emphasis added).

${ }^{419}$ Cf. Matthew Josephson, The Robber Barons: The Great AMERiCAn Capitalists 1861-1901 (2010); but $c f$. Burton W. Folsom, THE MYTH OF THE RobBER BARONS: A NEW LOOK AT THE Rise OF Big BUSINESS IN AMERICA (1991).

${ }^{420} 26$ Stat. 209, 15 U.S.C. $\S \S 1-7$.

42138 Stat. 73015 U.S.C. §§ 12-27, 29 U.S.C. §§ 52-53.
} 
monopolies, perhaps facilitated by Crony Capitalism. For example, the Alabama Constitution

provided in 1901 that:

The legislature shall provide by law for the regulation, prohibition, or reasonable restraint of common carriers, partnerships, associations, trusts, monopolies, and combinations of capital, so as to prevent them or any of them from making scarce articles of necessity, trade, or commerce, or from increasing unreasonably the cost thereof to the consumer, or preventing reasonable competition in any calling, trade, or business. ${ }^{422}$

Similarly, the Minnesota Constitution stated in 1888 that:

Any combination of persons, either as individuals or members or officers of any corporation to monopolize the markets for food products in this state, or to interfere with, or to restrict the freedom of such markets, is hereby declared to be a criminal conspiracy and shall be punished in such manner as the Legislature shall provide. ${ }^{423}$

In 1911, the New Mexico Constitution stated that "The legislature shall enact laws to prevent trusts, monopolies and combinations in restraint of trade." ${ }^{424}$ Other states to include these types of provisions are Washington in $1889,{ }^{425}$ Kentucky in $1891,{ }^{426}$ Utah in $1895,{ }^{427}$ South Dakota in 1896, ${ }^{428}$ New Hampshire in $1903,{ }^{429}$ and Arizona in $1910 .{ }^{430}$

\footnotetext{
${ }^{422}$ ALA. CONST., art. IV, § 103.

${ }^{423}$ MinN. CONST. OF 1888, 4, § 35.

${ }^{424}$ N.M. CONST., art. 4 , § 38.

${ }^{425}$ WASH. CONST. OF 1889, art. 12, § 22:
}

Monopolies and trusts shall never be allowed in this state, and no incorporated company, copartnership, or association of persons in this state shall directly or indirectly combine or make any contract ... for the purpose of fixing the price or limiting the production or regulating the transportation of any product or commodity. The legislature shall pass laws for the enforcement of this section by adequate penalties, and in case of incorporated companies, if necessary for that purpose, may declare a forfeiture of their franchises.

${ }^{426}$ KY CONST. OF 1891, § 198.

${ }^{427}$ UTAH CONST. OF 1895, art. 12, § 20 :

Any combination by individuals, corporations, or associations, having for its object or effect the controlling of the price of any products of the soil, or of any article of manufacture or commerce, or the cost of exchange or transportation, is prohibited, and hereby declared unlawful, and against public policy. The Legislature shall pass laws for the enforcement of this section by adequate penalties, and in case of incorporated companies, if necessary for that purpose, it may declare a forfeiture of their franchise.

${ }^{428}$ S.D. CONST. OF 1896, art. 17, § 20 (note that South Dakota also prohibited exclusive privileges granted by the state as well): 
The Oklahoma Constitution of 1907 said that the state legislature "shall define what is an unlawful combination, monopoly, trust, act, or agreement, in restraint of trade” ${ }^{431}$ and "enact laws to punish persons engaged in any unlawful combination, monopoly, trust, act, or agreement, in restraint of trade, or composing any such monopoly, trust, or combination." ${ }^{432}$ Perhaps more so than all other state provisions during this period, Oklahoma's constitution reflects the shift from concern over government abuse of power in granting monopolies to a fear of the power of private companies.

It is important to note that not all changes to state constitutions regarding monopolies during this period were concerned with private monopolies. For example, when Wyoming's Constitution was adopted in 1889, it provided that "Perpetuities and monopolies are contrary to the genius of a free state, and shall not be allowed. ..."433 Thus, Wyoming included language

Monopolies and trusts shall never be allowed in this state and no incorporated company, copartnership or association of persons in this state shall directly or indirectly combine or make any contract ... to fix the prices, limit the production or regulate the transportation of any product or commodity so as to prevent competition in such prices, production or transportation or to establish excessive prices therefor. ... The Legislature shall pass laws for the enforcement of this section by adequate penalties and in the case of incorporated companies, if necessary for that purpose may, as a penalty, declare a forfeiture of their franchises.

${ }^{429}$ N.H. CONST., art. 83:

Free and fair competition in the trades and industries is an inherent and essential right of the people and should be protected against all monopolies and conspiracies which tend to hinder or destroy it. The size and functions of all corporations should be so limited and regulated as to prohibit fictitious capitalization and provision should be made for the supervision and government thereof. Therefore, all just power possessed by the state is hereby granted to the general court to enact laws to prevent the operations within the state of all persons and associations, and all trusts and corporations, foreign or domestic, and the officers thereof, who endeavor to raise the price of any article of commerce or to destroy free and fair competition in the trades and industries through combination, conspiracy, monopoly, or any other unfair means; to control and regulate the acts of all such persons, associations, corporations, trusts, and officials doing business within the state; to prevent fictitious capitalization; and to authorize civil and criminal proceedings in respect to all the wrongs herein declared against.

${ }^{430}$ ARIZ. CONST. OF 1910, art. XIV, § 15.

${ }^{431}$ OKLA. CONST., art. 5, § 44 (emphasis added).

${ }^{432} I d$.

${ }^{433}$ WYO. CONST., art. 1, § 30. 
that was nearly identical to the older provisions prohibiting state-granted monopolies during a period when most state constitutional amendments were including provisions to prohibit private, not state-granted, monopolies.

\section{The Application of Those Provisions}

A survey of all of the case law regarding antimonopoly provisions in state constitutions provides, not surprisingly, that states whose amendments were adopted at the Founding until the 1870s provide the strongest protections against state-granted monopolies. However, there were two instances found where courts in states with Progressive-era provisions aimed at so-called private monopolies indicated that these provisions might also be used to protect against state granted monopolies. ${ }^{434}$ Regardless, these provisions have proven to be an important method for the protection of economic rights. State courts have recognized the English roots from which the concern about monopolies arose. For example, as the Arkansas Supreme Court pointed out:

The monopolies which in England became so odious as to excite general opposition, and infuse a detestation which has been transmitted to the free States of America, were in the nature of exclusive privileges of trade, granted to favorites or purchasers from the crown, for the enrichment of individuals, at the cost of the public. They were supported by no considerations of public good. They enabled a few to oppress the community by undue charges for goods or services. The memory, and historical traditions, of abuses resulting from this practice, has left the impression that they are dangerous to Liberty, and it is this kind of monopoly, against which the constitutional provision is directed. ${ }^{435}$

This Section discusses four principle areas where statutes have been struck down under antimonopoly provisions in state constitutions: (A) industry licensing requirements; (B) taxes designed to benefit preferred industries; (C) monopolies to do business with the government

\footnotetext{
${ }^{434}$ See Arnold v. Bd. of Barbers, 109 P.2d 779 (N.M. 1957) (A New Mexico case upholding a statute which required minimum price levels for barbers but acknowledging that the antimonopoly provisions required the state legislature to avoid monopolies); Schmidt v. Nord, 27 N.W.2d 910 (S.D. 1947) (A South Dakota case upholding a tax on butter substitutes but stating that if the tax was used to subsidize the butter industry, it would be unconstitutional).

${ }^{435}$ N. Little Rock Transp. Co. v. City of North Little Rock, 184 S.W.2d 52 (Ark. 1944) (quoting Ex parte Levy, 51 Am. Rep. 550 (Ark. 1884)).
} 
itself; and (D) price controls designed to benefit insiders. These twentieth century cases suggest that antimonopoly provisions-along with other economic liberty enhancing provisions such as Lockean provisos, equal protection, due process, and privileges and immunities clauses—may be useful for challenging preferential economic regulations today. Despite their usefulness, Subsection E explores potential reasons why most states have not adopted antimonopoly provisions, since only eight states prohibit the grant of monopolies by the state in their states' constitutions today and most modern antimonopoly provisions prohibit only so-called private monopolies.

\section{Challenging Licensing Requirements}

The first, and most promising, area for antimonopoly provisions to be used concerns the prohibition of licensing requirements to work in a specific trade. A survey of the case law found that antimonopoly provisions have been used to strike down licensing requirements in: building hospitals, ${ }^{436}$ providing ambulance services, ${ }^{437}$ tile placing, ${ }^{438}$ car dealerships, ${ }^{439}$ photography, ${ }^{440}$ dry cleaning, ${ }^{441}$ gas stations (which was a victory for Standard Oil, no less), ${ }^{442}$ and taxi cabs. ${ }^{443}$

Important to the occupational licensing decisions is the level of skill that is required. If a trade is a relatively easy trade to learn, the court is more likely to strike down an occupational licensing law since this would be an impermissible extension of the state's police power. For example, in Roller v. Allen, where the Supreme Court of North Carolina struck down a licensing regulation for those in the tile placing industry, the court emphasized that the trade is "simple,

\footnotetext{
${ }^{436}$ In re Certificate of Need for Aston Park Hosp., 193 S.E.2d 729 (N.C. 1973).

${ }^{437}$ Whaley v. Lenoir Cnty., 168 S.E.2d 411 (N.C. 1969).

${ }^{438}$ Roller v. Allen, 96 S.E.2d 851 (N.C. 1957).

${ }^{439}$ Georgia Franchise Practices Comm’n v. Massey-Ferguson, Inc., 262 S.E.2d 106 (Ga. 1979).

${ }^{440}$ State v. Ballance, 51 S.E.2d 731 (N.C. 1949) (the court also struck this statute down for violating its "Lockean Proviso" in Art. 1, Section 1 and due process under Art. 1, Section 17).

${ }^{441}$ State v. Harris, 6 S.E.2d 854 (N.C. 1940).

${ }^{442}$ Town of Clinton v. Standard Oil, 137 S.E. 183 (N.C. 1927).

${ }^{443}$ Checker Cab Co. v. City of Johnson City, 216 S.W.2d 335 (Tenn. 1948); N. Little Rock Transp. v. City of N. Little Rock, 184 S.W.2d 52 (Ark. 1944).
} 
easy to learn, and requires no special skill” and thus there was an absence of a public interest in regulating the trade. ${ }^{444}$

Because professions such as law and medicine tend to require much more specialized skill and training than other occupations (like placing tile, photography, and dry cleaning), the imposition of licensing requirements in these industries can be justified as valid exercises of the state's police power. The primary problem with licensing requirements which have been struck down under state anti-monopoly clauses is that there was little to no concern in those cases about public health and safety considerations that might justify occupational licensing. Rather, the impetus for imposing occupational licensing requirements in those cases was entirely to promote special interests - an interest of photographers and dry cleaners already working in the industry to limit the entry of others in order to stifle competition to maximize their rents.

By contrast, in areas such as law and medicine, generally considerable skill and training are required in order to practice in the industry. If someone is holding themselves out to be a doctor, but does not actually have the qualifications normally expected of a doctor, the consequences could very well be tragic. However, there is little harm that can be done to another's health if a photographer is not specially trained under the requirements set up to obtain a license to be a photographer. It is undoubtedly true that lawyers and doctors do encourage limitations on the granting of licenses in order to limit the number of entrants into their respective industries. However, the primary social motivation for licensing requirements in highly skilled industries is not to cap the number of people in the industry, but rather to protect the public from the potential negative consequences of receiving services which require unusual expertise from an unlicensed_-and thus likely untrained—medical or legal professional.

\footnotetext{
${ }^{444}$ Roller v. Allen, 96 S.E.2d 851, 854 (N.C. 1957).
} 
This is not to say that licensing requirements for more highly trained professions, such as engineering, medicine, and law, are absolutely necessary. Given the self-regulation of many industries, including the aforementioned industries themselves, there is good reason to believe that self-regulation (and even self-imposed licensing requirements) would guard against many of the health and safety concerns that give rise to legally mandated licensing requirements by the state. However, since the primary justification for licensing requirements in more highly skilled professions is health and safety concerns-not the protection of special interests-occupational licensure is more easily justifiable in those professions.

An important consideration for courts is who controls the distribution of licenses. If a state licensing board is controlled by those who already work in the industry, the statute requiring occupational licensing is unlikely to be upheld. This is obviously because the board is more likely to promote a monopoly when the distribution of licenses is controlled by people who are already working in the industry. This rational is the same as the rational used in $D r$. Bonham's Case, the seventeenth century English case famous for Sir Edward Coke’s holding that the common law controlled acts of Parliament. In Dr. Bonham's Case, the court struck down a patent granted by King Henry VIII, later confirmed by statute, which gave the Royal College of Physicians the power to impose fines on physicians who had not been licensed by the College to practice medicine there. ${ }^{445}$ The fact that Royal College of Physicians received half of all fines meant that the doctors were "not only judges but also actual parties to any cause of action before them,” and this was a key part of the reason Sir Edward Coke gave for striking down the law. ${ }^{446}$ For example, in Roller, the aforementioned North Carolina case, all the

\footnotetext{
44577 Eng. Rep. 646 (1610); George P. Smith, Dr. Bonham's Case and the Modern Significance of Lord Coke's Influence, 41 WASH. L. REV. 297, 302 (1966).

${ }^{446}$ George P. Smith, Dr. Bonham's Case and the Modern Significance of Lord Coke's Influence, 41 WASH. L. REV. 297, 304 (1966).
} 
members of the occupational licensing board came from the tile placing industry itself. ${ }^{447}$ This was also an important consideration in State v. Harris, in which the Supreme Court of North Carolina struck down a law creating a "State Cleaners Commission." 448 Noting that such boards are the equivalent of private trade guilds, the court suggested that the boards were even more damaging to the public once sanctioned by the state since they had the force of the criminal courts behind them. ${ }^{449}$

Historically, North Carolina has had the most successful challenges in the licensing area. Perhaps not surprisingly, North Carolina was one of the two states which had an antimonopoly provision in its state constitution since the founding. ${ }^{450}$ However, recent case law in North Carolina suggests that its antimonopoly provision may not provide as strong protection today as was formerly the case. In American Motors Sales v. Peters in 1984, North Carolina's Supreme Court held that a statute which made it unlawful for a car manufacturer to grant a franchise in what the state determined to be a trade area that was already sufficiently served by a dealer or dealers did not violate the state's antimonopoly clause even though there was only one dealer in the area. ${ }^{451}$ The court distinguished the case from an almost identical law that was struck down in Georgia on the grounds that Georgia's constitution (at the time) also prohibited laws that lessen competition, while the North Carolina constitution only prohibits monopolies. ${ }^{452}$ However, this recent holding is difficult to reconcile with other cases in North Carolina, since the laws in the other cases (Roller v. Allen and State v. Harris) also tended to lessen competition but did not create outright monopolies.

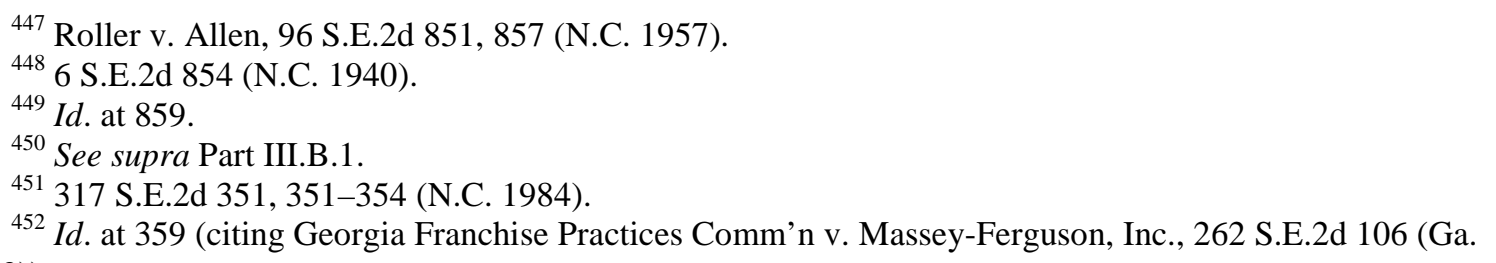
1979)). 
Another consideration calling into question the effectiveness of antimonopoly provisions today is that many of these cases were brought forty or more years ago, and thus it is unclear how courts would treat challenges under these clauses today. Challenges are still being brought under state antimonopoly provisions to strike down occupational licensing laws today. For example, there were two recent cases challenging licensing requirements under antimonopoly provisions, among other claims, in Maryland in 2009 and in Texas in 2010. However, both regulations were struck down on other grounds. In Texas, the trial court struck down a law which prohibited non-dentists from "floating" (grinding down) horses' teeth. ${ }^{453}$ The court ultimately found that it violated Texas administrative law rulemaking procedures. ${ }^{454}$ In Maryland, the trial court granted summary judgment to an owner of a horse massage business (who worked in the industry for more than thirty years) when the Board of Chiropractic Examiners sought to ban her from the trade. ${ }^{455}$ The court held that Maryland's Board of Chiropractic Examiners had no authority to regulate the horse massage industry. ${ }^{456}$

\section{Striking Down Taxes that Benefit Preferred Industries}

Another area in which state constitutional antimonopoly clauses have been used is in challenging the validity of laws that impose taxes on some parties in order to benefit others. For example, in Appeal of Arcadia Dairy Farms, the Court of Appeals of North Carolina struck down a statute which provided tax and equalization payments to North Carolina milk producers

${ }^{453}$ See Texas Equine Dentistry, InST. FOR JusTICE, http://www.ij.org/economicliberty/650 (last visited Mar. 16, 2011); see also Challenging Texas’ Elitist Veterinary Cartel, INST. FOR JUSTICE, http://www.ij.org/index.php?option=com_content\&task=view\&id=651\&Itemid=165 (last visited Mar. 14, 2011).

${ }^{454}$ Email correspondence with Clark Neily at the Institute for Justice (Mar. 15, 2011).

${ }^{455}$ See Fighting Maryland's Veterinary Cartel, INST. FOR JUSTICE, http://www.ij.org/economicliberty/2203 (last visited Mar. 16, 2011); see also Challenging Barriers to Economic Opportunity: Freeing Maryland Entrepreneurs from the Chiropractic and Veterinary Cartels, INST. FOR JUSTICE, http://www.ij.org/index.php?option=com_content\&task=view\&id=2204\&Itemid=129 (last visited Mar. 14, 2011).

${ }^{456}$ See Fighting Maryland's Veterinary Cartel, INST. FOR JUSTICE, http://www.ij.org/economicliberty/2203 (last visited Mar. 16, 2011); Email correspondence with Clark Neily at the Institute for Justice (Mar. 15, 2011). 
as invalid under the state constitution's antimonopoly clause. ${ }^{457}$ In discussing the lack of a public purpose for the statute, the court pointed out that the statute's entire goal was to require dairy producers to pay competitors—not to improve the quality of milk for consumers. ${ }^{458}$

However, as an example of the application of a Progressive era antimonopoly provision, the Supreme Court of South Dakota refused to strike down a law which taxed margarine but not butter. ${ }^{459}$ While the court acknowledged that if the funds received went directly to the butter industry the law would have contravened the antimonopoly provision, since the funds went to a general pool, the court held that the law was constitutional. ${ }^{460}$

Nevertheless, with the application of a bit of economic theory, it is easy to see that the distinction drawn by the South Dakota Supreme Court should not really have mattered. To the extent margarine is a substitute for butter (which in many cases it is), a tax on margarine will raise its cost to consumers. Thus, on the margin, consumers will switch to other substitutes, such as butter. This will tend to encourage a monopoly for the butter industry because consumers will be encouraged by an increase in the price of margarine to switch to consuming butter instead. Of course, the economic effects would likely not be as drastic as if the taxes charged to the margarine industry were directly used to pay the butter industry. However, the law's tendency to create monopoly would still remain and the motivation for the law in this case was undoubtedly to benefit the butter industry at the expense of its main competitor.

\section{Challenging Monopolies for Doing Business with the Government}

Both Maryland and Arkansas's provisions have been used to strike down laws which give private parties a monopoly for doing business with the government. Like Maryland's

\footnotetext{
${ }^{457} 259$ S.E.2d 368, 368 (N.C. 1979).

${ }^{458} I d$. at 372.

${ }^{459}$ Schmitt v. Nord, 27 N.W.2d 910 (S.D. 1947).

${ }^{460} I d$. at 916.
} 
constitution, Arkansas’s constitution provides the traditional language: “. . . monopolies are contrary to the genius of a republic, and shall not be allowed.”461

For example, in Raney v. County Commissioners of Montgomery County, the Court of Appeals of Maryland (the state's highest court) struck down a law in 1936 which granted a monopoly for public notices in newspapers. ${ }^{462}$ Importantly, when discussing Maryland's antimonopoly provisions, the court emphasized that because Maryland's constitution otherwise did not denounce special privileges, it was necessary to understand the antimonopoly language broadly so as to "safeguard the citizen in the enjoyment of privileges and immunities which were regarded as of common right.”463

The antimonopoly provision was similarly relied on in Alphin v. Henson. ${ }^{464}$ The United States District Court for the District of Maryland dealt with the issue of whether the city could grant the power to one individual to conduct all negotiations at a municipal regional airport under the Sherman and Clayton Antitrust Acts. ${ }^{465}$ In granting an injunction, the court relied on Raney, noting that Maryland's constitutional prohibition on monopolies weighed in favor of its decision. ${ }^{466}$ In Upchurch v. Adelsberger, the Supreme Court of Arkansas also struck down a city ordinance which required that materials printed for the city bear a specific labor union's label_thus giving all of its printing work to one labor union-under the state's antimonopoly provision. ${ }^{467}$

${ }^{461}$ ARK. CONST. OF 1874, art. 2, § 19.

462183 A. 548, 554-55 (1936).

${ }^{463} \mathrm{Id}$. at 551 (stating that, "when the meaning to be given the word "monopoly" as used in article 41 is considered, great weight is to be given to the fact that but for that article the Constitution affords to the citizen no express protection against special and oppressive privilege" and "In determining the sense in which it is used in that instrument, it should be given that meaning that its general intent may be served, rather than thwarted or confined by any narrow or overnice construction.”).

464392 F. Supp. 813 (D. Md. 1975).

${ }^{465}$ Id. at 826-27.

${ }^{466}$ Alphin, 392 F. Supp. at 829 (quoting Raney, 183 A. at 551).

${ }^{467} 332$ S.W.2d 242 (Ark. 1960). 
Although antimonopoly provisions may be used to strike down monopolies to do business with local governments, it is generally permissible for local governments to enter contracts with private parties which give those parties the exclusive right to provide public services, such as utilities like water, gas, and electricity. ${ }^{468}$ This may be defended on the grounds that these kinds of public services are considered "natural monopolies." That is, where capital costs are especially high in a particular industry, there are especially high barriers to entry. Thus, there are large economies of scale, so it is optimal to only have one supplier in the industry.

The existence of natural monopolies has been challenged by some free-market economists, ${ }^{469}$ suggesting that the need for grants of monopoly for public utilities is unwarranted. However, the justification for granting these kinds of monopolies appears to be based on an economic rationale rather than as a result of the desire to protect special interests. Thus, the rationale for striking down laws under antimonopoly provisions (to guard against states granting privileges in order to protect special interests) does not appear to be implicated when local governments grant monopolies for public utilities.

\section{Combating Price Controls}

The Supreme Court's decisions in West Coast Hotel Co. v. Parrish, ${ }^{470}$ upholding the constitutionality of a minimum wage law, and Nebbia v. People of New York, ${ }^{471}$ upholding the constitutionality of a state board which fixed the price of milk, enabled states to justify their own minimum wage and fee laws. ${ }^{472}$ However, two states with antimonopoly provisions were faced

\footnotetext{
${ }^{468}$ See, e.g., City of Memphis v. The Memphis Water Co., 52 Tenn. 495 (1871).

${ }^{469}$ See MURRAY ROTHBARD, POWER AND MARKET: GOVERNMENT AND THE ECONOMY (1970); Thomas J. DiLorenzo, The Myth of the Natural Monopoly, 9 REV. OF AustRIAn ECON. 43 (1996).

${ }^{470} 300$ U.S. 379, 398 (1937) (asking, "if the protection of women is a legitimate end of the exercise of state power, how can it be said that the requirement of the payment of a minimum wage fairly fixed in order to meet the very necessities of existence is not an admissible means to that end?").

${ }^{471} 291$ U.S. 502 (1934).

472 See, e.g., Brd. of Barber Exam'rs v. Parker, 182 So. 485 (La. 1938); Jarvis v. State Brd. of Barber Exam'rs, 83 P.2d 560 (Okla. 1938); Herrin v. Arnold, 82 P.2d 97 (Okla. 1938).
} 
with the question of whether these regulations were constitutional under their state constitutions' antimonopoly provisions.

In 1957 in Arnold v. Board of Barbers, the Supreme Court of New Mexico upheld the validity of a statute which established a "Board of Barbers" and set minimum price requirements for paying barbers. ${ }^{473}$ In noting that great deference must be given to the legislature in determining whether the law serves a public purpose, the court held that requiring minimum prices for barber services is related to the sanitary conditions of barber shops and thus was not unconstitutional. ${ }^{474}$ Interestingly, however (since this was a Progressive-era provision) the court acknowledged that the antimonopoly provision in its state constitution "enjoins upon the legislature a policy opposed to trusts, monopolies and combinations in restraint of trade.”475 Thus, New Mexico's antimonopoly clause may be interpreted broadly to prohibit state-granted monopolies. Nonetheless, the court failed to find that the statutes tended to confer monopoly rents, although members of the board came "exclusively from those engaged in the profession or business of barbering." ${ }^{476}$

However, the Supreme Court of Arkansas in 1942, relying on a more traditional antimonopoly provision adopted at a time when such provisions were aimed at state grants of monopoly, in Noble v. Davis struck down a nearly identical statute to the New Mexico statute, which established minimum prices for barbers which were determined by the State Board of Barber Examiners. ${ }^{477}$ The plaintiff charged twenty-five cents for a haircut while the Board mandated a fee of at least forty cents. ${ }^{478}$ Looking at the long history of the barber industry,

\footnotetext{
473109 P.2d 779 (N.M. 1957).

${ }^{474} \mathrm{Id}$. at 787 .

${ }^{475}$ Id. at 786 .

${ }^{476} \mathrm{Id}$.

477161 S.W.2d 189 (Ark. 1942).

${ }^{478} \mathrm{Id}$. at 189.
} 
dating back to the time of the Romans, the Supreme Court of Arkansas found that the profession was one historically of common right—echoing Sir Edward Coke-and thus could not be regulated except as required under the police power of the state. ${ }^{479}$ The Court held that where the Board only regulated with respect to economic issues—such as minimum prices and opening hours-such regulations could not be upheld as serving the public purpose under the state's police power. ${ }^{480}$

The use of an antimonopoly provision to strike down a law that merely imposes price requirements requires an expansive view of the clause's language and history. The historical concern with state-granted monopolies suggests that state constitutional antimonopoly clauses were primarily intended to prohibit outright prohibitions on entering an industry rather than indirect barriers to entering an industry, such as minimum price requirements. The Board of Barbers may have recognized that strict licensing requirements would have been easily struck down under the Arkansas Constitution's ban on monopolies, and thus it might have sought to circumvent that constitutional prohibition through an indirect barrier to entry. The Board of Barbers was also undoubtedly helped by the U.S. Supreme Court's ruling in West Coast Hotel, which upheld a minimum wage law and overruled Adkins v. Children's Hospital. However, the Supreme Court of Arkansas court correctly saw the intended consequences of the minimum pricing law— to indirectly establish barriers to enter the barber industry for no other reason than to protect the interests of barbers already working in the industry.

\section{Why Have So Few States Adopted Antimonopoly Provisions?}

Many states have adopted antimonopoly provisions and similar prohibitions on exclusive privileges. The Case of Monopolies and Statute of Monopolies were very important in English

\footnotetext{
${ }^{479} I d$. at 190.

${ }^{480}$ Id. at 191.
} 
legal history and the consequences which flowed from allowing state-granted monopolies were especially feared by the English people. Those concerns carried over to America, as is shown by a number of statements from the Founders and from the Antifederalists. Thus, it is perhaps surprising that so few states have adopted explicit antimonopoly clauses in their state constitutions today.

A potential explanation is that many states probably did not feel compelled to adopt antimonopoly clauses because their constitutions already included provisions which protected economic liberty in other ways and which dealt with many of the same concerns the antimonopoly clauses were intended to protect against. Other provisions that tend to be important for and to protect economic liberty include: 1) privileges and immunities clauses, 2) due process clauses, 3) takings clauses, 4) Lockean provisos (which are broad guarantees of inalienable, natural, or inherent rights ${ }^{481}$ ), 5) free speech clauses, and 6) equal protection clauses.

The addition of an antimonopoly clauses alongside, for example, the protection of an individual's privileges and immunities, may appear superfluous. For instance, in State v. Ballance, the Supreme Court of North Carolina struck down a law requiring licenses for photographers under the due process clause and the state constitution's Lockean proviso as well as the antimonopoly provision. ${ }^{482}$ Another example is the Maryland Supreme Court's decision in Raney. In that case, the Court found persuasive the fact that Maryland's constitution, unlike

${ }^{481}$ A typical example can be found in Virginia’s Constitution, which states:

That all men are by nature equally free and independent, and have certain inherent rights, of which, when they enter into a state of society, they cannot, by any compact, deprive or divest their posterity; namely, the enjoyment of life and liberty, with the means of acquiring and possessing property, and pursuing and obtaining happiness and safety.

VA CONST. BILl Of RightS § 1 (1864); see also Steven G. Calabresi \& Sofia Vickery, On Liberty and the Fourteenth Amendment: The Original Understanding of the Lockean Provisos (draft as of June 12, 2011, on file with author).

${ }^{482}$ State v. Ballance, 51 S.E.2d 731 (N.C. 1949). 
the constitutions of other states, contained no other clauses except for the antimonopoly clause which would protect against the granting of special privileges. ${ }^{483}$ Thus, a desire for simplicity and brevity might cause a state constitution's drafter to see little reason to add an antimonopoly provision to its constitution when other provisions already protect similar bundles of rights.

Another probable reason as to why not all states have constitutional antimonopoly clauses is that since the New Deal concern with protecting economic liberty has greatly diminished. As a result of the New Deal, economic liberties are subjected to what some have called "toothless" ${ }^{484}$ rational basis review. Courts are now extremely reluctant to strike down economic regulations and legislatures are especially eager to impose economic regulations at the state level. Moreover, the fact that there was a shift in the Progressive Era to prevent privately created monopolies instead of state-granted monopolies in state constitutions also reflects a change in popular views about where power should be concentrated. Perhaps this is also a reflection of public sentiment (or complacency) in the area of protecting economic liberty.

As was discussed above, although several states have provisions that ban state-created monopolies in their constitutions today, these clauses have often not regularly been used and state courts have become increasingly less likely to strike down laws under these clauses. As the recent challenges in Maryland (involving horse massage) and Texas (involving horse teeth grinding) illustrate, courts may be more likely to strike down such laws on other grounds. That is, it is perhaps easier-and less controversial—to strike down laws as violations of administrative rulemaking requirements than as violations of the more expansive prohibition on state granted monopolies, which would in turn call into question the validity of many other

\footnotetext{
${ }^{483}$ Raney v. Cnty. Comm’rs of Montgomery Cnty., 183 A. 548, 551 (1936).

${ }^{484}$ In re Agnew, 144 F.3d 1013, 1014 (7th Cir. 1998) (per curiam) (finding that although the "clear error or abuse of discretion is deferential, it is not toothless after the fashion of review for a rational basis”); see also Clark Neily, No Such Thing: Litigating Under the Rational Basis Test, 1 N.Y.U. J. L. \& LIBERTY 898 (2005).
} 
economic regulations. Thus, although state constitutions are amended much more frequently than is the federal constitution, it is unlikely that an antimonopoly provision would be a priority for drafters of modern state constitutions.

\section{CONCLUSION}

While the evils of state granted monopolies in England did not lead to an antimonopoly provision in the federal constitution, there is ample evidence that the right to be free from government monopolies is deeply rooted in this country's history and tradition. The English fear of monopolies was a fear that Americans experienced under colonial rule, and it provided one of many justifications put forward for American independence. The Antifederalists spoke out against monopolies, and Federalists such as James Madison discussed the issue with Thomas Jefferson and George Mason during the debates on the Constitution. During the ratification of the federal Constitution, six states even requested the inclusion of an antimonopoly clause as an amendment to the Constitution. In addition, Congress is only given enumerated power to create monopolies in the Patent and copyright context, which implies that Congress lacks such power in other contexts. Moreove, the Privileges and Immunities Clause of Article IV may very well have recognized a constitutional right to be free from partial or discriminatory laws. Two states had antimonopoly provisions in their constitutions at the time of the founding, and many more states added antimonopoly provisions to their constitutions during the nineteenth century due to the Jacksonian concern about monopolies. This thread of Jacksonian thought was adopted by the Abolitionists and then by Reconstruction era Republicans who argued that the institution of slavery was itself a particularly perverse monopoly. The antimonopoly argument thus played an important role in the writing of the Fourteenth Amendment, which for the Radical Republicans was a ban on all systems of class-based legislation, of exclusive privileges, and of monopolies. 
All of this evidence-from Seventeenth Century England, from the colonial period, from the experience in the states, and from the framing of the Fourteenth Amendment-makes it clear that there is a strong antimonopoly tradition in U.S. constitutional law.

The fact that in recent times the federal courts have, for the most part, relegated cases involving economic regulations to limited "rational basis" review, however, has meant that until recently challenges to laws on antimonopoly grounds were unlikely to be successful. This may change now that the rational basis test has been employed to strike down classifications on the basis of sex, sexual orientation, and mental retardation, and now that the Takings Clause is experiencing a revival at the level of the U.S. Supreme Court. Despite the post New Deal rational basis mindset, this article has shown that state antimonopoly clauses in particular have proven to be important for striking down a number of economic regulations that grant special privileges to some at the expense of others-licensing requirements, taxes designed to benefit preferred industries, monopolies to do business with the government, and price controls designed to benefit insiders. Antimonopoly clauses can also be used to strike down laws such as licensing requirements where the court finds that the laws grant special privilege absent any health and safety concerns. Challenges to state laws on antimonopoly grounds have been made recently, such as with a law governing Maryland horse massages and with the Texas horse floating cases discussed in Section III.

The right to compete, and more fundamentally, the right to earn an honest living, is a basic right embodied in U.S. constitutional law. There is substantial evidence, from the English and colonial history, from debates on the federal constitution and its ratification, from the history of the Fourteenth Amendment, and from state constitutional law, to show that this is the case. However, the longstanding use of rational basis review has meant that the courts have too often 
surrendered to a legislative process that is dominated by well-entrenched interest groups seeking monopoly rents from the state. It means that fundamental economic liberties too often go unprotected by the courts. In short, the use of rational basis review has meant that "property is at the mercy of the pillagers." 485 As this article has shown, however, "the constitutional guarantee of liberty deserves more respect—a lot more.”486

${ }^{485}$ Hettinga v. United States, No. 11-6065 (D.C. Cir. 2012), available at http://www.cadc.uscourts.gov/internet/opinions.nsf/70A27D44D7C03503852579DF004EF65F/\$file/11-50651368692.pdf.

${ }^{486} I d$. 